Studies in Heredity as Illustrated by the Trichomes of Species and Hybrids of Juglans, Oenothera,

\title{
Papaver, and Solanum
}

BY

WILLIAM AUSTIN CANNON

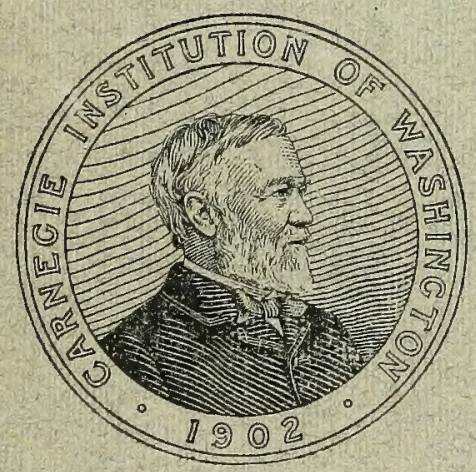

WASHINGTON, D. C.

PUblished hy the Carnegie Instrtution of Washington 


\section{Cornell University Library}

The original of this book is in the Cornell University Library.

There are no known copyright restrictions in the United States on the use of the text.

http://www.archive.org/details/cu31924000581623 
Studies in heredity as Illustrated by th

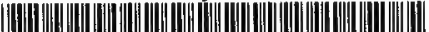

31924000581623 


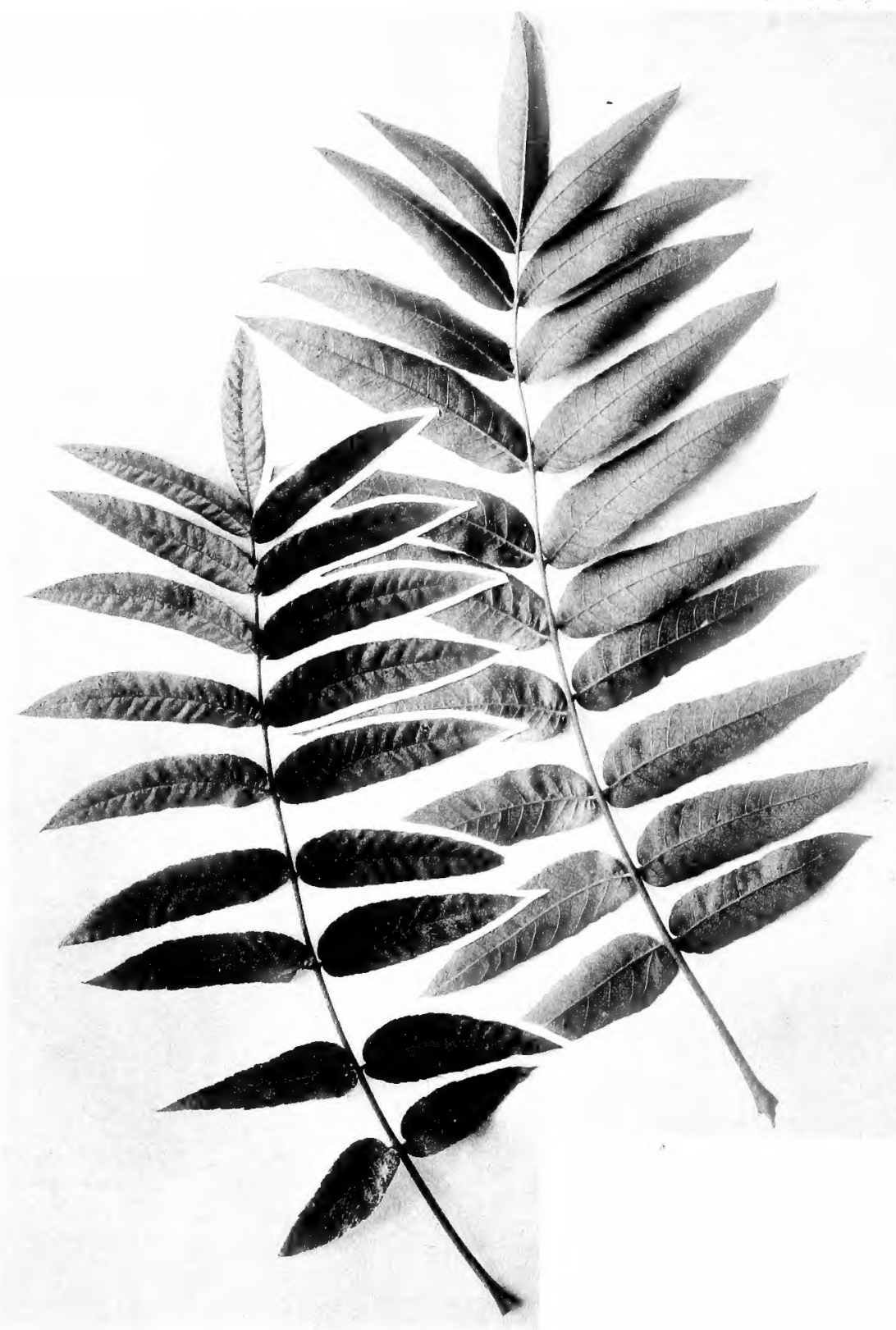

Dorsal and ventral surfaces of typical leaves of Juglans californica, taken from a tree growing in Santa Rosa, California. One-third natural size. 


\section{Studies in Heredity as Illustrated by the Trichomes} of Species and Hybrids of Juglans, Oenothera, Papaver, and Solanum

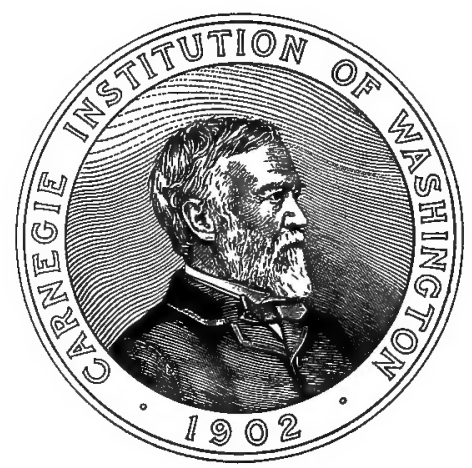

WASHINGTON, D. C.

Published by the Carnegie Institution of Washington 1909 


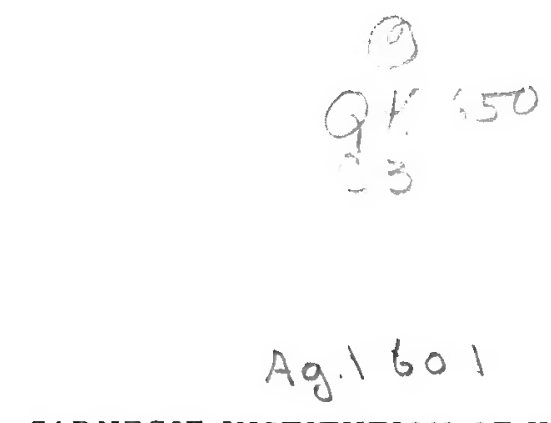

CARNEGIE INSTITUTION OF WASHINGTON

Publication No. iI 7

Copies of this Book

were first issued

OCT 221909

THE CORNMAN PRINTING COMPANY, CA RLIGLE, PEN NGYLVANIA. 


\section{CONTENTS.}

Introduction

Page

Scope and purpose of the study.....

Pure species and hybrids examined

Trichomes of Oenothera lamarckiana $\times$ Oenothera cruciata and of the parental lines

Oenothera lamarckiana.

Oenothera cruciata

Oenothera lamarckiana $\times$ Oenothera cruciata.

Comparison of trichomes of the Oenotheras

Trichomes of Papaver hybrids and pure species.

Trichomes of the pure species

Papaver somniferum $\times$ Papaver orientale

Papaver somniferum $\times$ Papaver pilosum

Trichomes of Solanum villosum $\times$ Solanum guinense and of the pure species...

Solanum villosum.

Solanum guinense

Solanum villosum $\times$ Solanum guin

Pure species and hybrids of

Leaves of the pure species

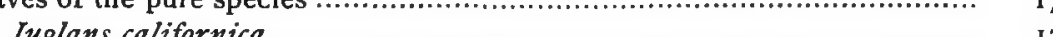

Juglans californica.............................................................. I

Juglans nigra ............................................................ 17

Juglans regia.................................................................... I 8

Trichomes of the pure species................................................. 18

Juglans californica........................................................ 19

Juglans nigra............................................................ $\quad 25$

Juglans regia.............................................................. 30

Comparison of leaves and trichomes of Juglans, pure species.................. 34

Hybrids of Juglans............................................................... 35

Leaves of the hybrids.......................................................... 35

Juglans californica $\times$ Juglans nigra..................................... 35

Juglans californica $\times$ Juglans regia......................................... 35

Trichomes of Juglans californica $\times$ Juglans nigra, first generation........ 37

Trichomes of Juglans californica $\times$ Juglans regia, first generation........ 40

Juglans hybrids, second generation.......................................... $4^{2}$

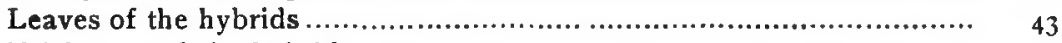

Trichomes of the hybrids................................................ 44

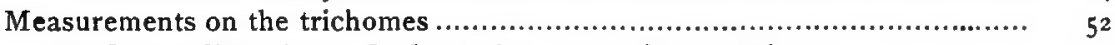

Juglans californica $\times$ Juglans nigra, second generation.................. $\quad 5^{2}$

Juglans californica $\times$ Juglans regia, second generation...................... 55

General comparison of trichomes in pure species and hybrids of Juglans..... 57

Conclusions and results .............................................................. 6 I

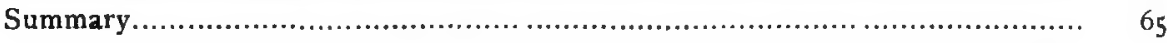




\section{STUDIES IN HEREDITY AS ILLUSTRATED BY THE TRICHOMES OF SPECIES AND HYBRIDS OF JUGLANS, OENOTHERA, PAPAVER, AND SOLANUM.}

\section{INTRODUCTION.}

\section{SCOPE AND PURPOSE OF THE STUDY.}

In investigating the structural features of plants two or more methods of approach, each especially adapted to the particular aim of the study, whatever it may be, may be employed. The entire anatomy of a few forms may be worked up, and appropriate comparisons instituted, or, on the other hand, special features of the plant's structure, such as the trichomes, may be minutely studied, both in the mature state and in embryonic condition, in a relatively large number of individuals as well as great variety of species. Although the former method has hitherto been the one chiefly employed in anatomical studies on plant hybrids, it seems appropriate, in view of the present tendency to regard a plant as a complex of more or less independent units, to institute the more special study. Whatever theories may be held, this manner of studying structures in plants, as in animals has long been found, has several advantages. It permits, in the first place, as suggested above, an examination into the behavior of the particular organ, or tissue, in a much larger number of plants than might otherwise be practicable, as, in the present instance, the trichomes of some 20 different kinds of plants, and many more individuals, have been passed under observation. It also favors an investigation into the variation of the particular structure, as well as into the relation of the variation to the organic and the physical environment of the tissue as possible causal factors of variation. Also, not only the mature structures, but the embryonic stages likewise, may be studied and compared, so that developmental stages may easily be contrasted, and, in favorable material, the possible origin of the structures may either be traced, or at least strongly surmised. And, finally, what is particularly important in a study on heredity, the behavior of the same structure may be advantageously observed throughout different generations. For these and other reasons the particular rather than the more general method of the study of the anatomy of the hybrids has been adopted in the present investigation.

In selecting plant structures for comparative study, one or two points were kept uppermost in mind. All of the plant tissues are not equally favor- 
able for such an investigation, for the reason, which is apparent, that they are either entirely inclosed by other tissues or so intimately related to such other tissues that the extent as well as the manner of development is largely conditioned by the development and position of such contiguous 1tissues. From the nature of things, structures so enveloped can, to a very imited degree only, whether representing "units" or not, develop as independent organs. However, even in wholly immersed structures, as the conductive system, the single-structure method of approach has been productive of rich results. But for the purpose of the present study it was essential that the tissues compared be as independent of other tissues as possible, and, in addition, should possess well-marked characteristics, both as mature structures and in embryonic stages; hence it was decided to select for the comparative study, as being most likely to give satisfactory results, the trichomal system.

The immediate objects of the investigation were, in brief, to study the origin, development, inheritance, and variation, and, so far as practicable, to observe the causes of variation of the trichomes in several pure species and the hybrids of the species. In addition, it was desired to trace the behavior of the structures in as many plants as possible, to the end that something exact might be known as to the relation between such tissues and unitcharacters; that is, to be more specific, it was proposed to learn, for example, whether the trichomal system as a whole constitutes a single unit, or whether each separate type of trichome of a plant is to be considered a distinct and independent character.

\section{PURE SPECIES AND HYBRIDS EXAMINED.}

The following hybrids, together with the pure lines, were studied: Juglans californica $\times$ Juglans nigra, $\mathrm{F}_{1}, \mathrm{~F}_{2}$, and $\mathrm{F}_{3} ;$ Juglans californica $\times$ Juglans regia, $\mathrm{F}_{1}, \mathrm{~F}_{2}$, and $\mathrm{F}_{3}$; Oenothera lamarckiana $\times$ Oenothera cruciata, $\mathrm{F}_{2}$ and $\mathrm{F}_{3}$; Papaver somniferum $\times$ Papaver orientale, $\mathrm{F}_{1}$; Papaver somniferum $X$ Papaver pilosum, $F_{1}$; Solanum villosum $\times$ Solanum guinense, $F_{1}, F_{2}$, and later generations.

The material for the study of the trichomes of the Oenothera hybrid was collected at the New York Botanical Garden in August, 1906, where it had been formed three years previously. In this cross* the characters of the pollen parent (Oenothera cruciata) are said largely to dominate, although none appear to be transmitted unchanged. Particularly in the flower there is a singular blending of the characters of both parents, as, for example, some of the hybrids have short stamens, lamarckiana-like, and are incapable of

\footnotetext{
* Mutants and Hybrids of the Oenotheras, by D. T. Macdougal and others, Carnegie Institution of Washington Publications 24 and $8 \mathrm{r}, 1905$.
} 
self-pollination, and others have long stamens, cruciata-like, and may be self-pollinated. Thus the hybrid does not in any character revert consistently to either parent. This is an example of the first cross breeding true.

The material for the study of the Juglans hybrids was collected at Mr. Luther Burbank's experimental grounds in Santa Rosia and Sebastopol, California, in 1907 and 1908, where, about 20 years before, Mr. Burbank had made the original crosses.

Juglans californica $\times$ Juglans nigra is represented by one tree of the first generation called the "Royal," and by numerous smaller trees of the second and third generations, the latter called the "Beeson," in the nursery at Sebastopol. Plates $4,5,6$, and 9 illustrate, though very inadequately, the variability of the leaves of the first, second, and third generations of this hybrid and show that the greatest range is probably to be found in the second generation, although those of the third are also extremely variable. The young trees of the later generations exhibit also great differences in size, as variation in this regard exceeding 500 per cent has been observed between those of like age and growing under apparently identical conditions.

Juglans californica $\times$ Juglans regia is represented by several trees of the first generation, known as the "Paradox," in Santa Rosa, and by numerous second and third generation seedlings at Sebastopol. Four Paradox trees are growing in the street in front of Mr. Burbank's residence. Although only 17 years from the seed, these trees are about 27 meters in height and their trunks are about 75 centimeters in diameter. The very luxuriant character of the tree is extended to the leaves, which in some instances are surprisingly long and are composed of leaflets which in number and size are said to exceed those of either parent. As will be presented somewhat in detail later in this paper, the leaves are also very variable in strface characters, in shape, size, and contour. Certain of these variations in the first and second generation plants are shown in plates 7 , 8 , and 10 .

The hybrids Papaver somniferum $\times$ Papaver orientale and Papaver somniferum $\times$ Papaver pilosum were produced by Mr. Burbank and are now growing at his experimental grounds in Santa Rosa, California. The parents of these hybrids, natives of southeastern Europe, the Caucasus region, and Asia Minor, are either annual (somniferum) or perennial, but the hybrids are perennial. Both of the Papaver hybrids are extremely variable, especially as regards the size, shape, and texture of the leaves and the size, color, and form of the flowers, and they are either wholly sterile ( $P$. somniferum $\times P$. orientale) or to a certain degree fertile. On account of the complete or partial sterility of these hybrids only the first generation has been available for study. 
Solanum villosum $\times$ Solanum guinense was produced by Mr. Burbank and is now growing in his experimental grounds at Santa Rosa, California. Solanum guinense, a native of central west Africa, is a perennial of bushy habit of growth, and bears black fruit of unpleasant flavor; Solanum villosum, from Chile, is an annual, dwarfed and procumbent, and bears clusters of small, hard, and green berries.* The hybrid is a low, bushy perennial, and produces berries agreeable to the taste, the flavor of which recalls that of the low-bush blueberry of the eastern United States. The hybrid has not been known to revert, although its culture, begun in 1897, has been carried to the fifth generation; it, therefore, is an instance of the breeding true of a first cross.

The material for study of all hybrids procured from Mr. Burbank was either collected by the writer and fixed in the usual manner, or was put up by Dr. G. H. Shull in weak formaldehyde. To both of these gentlemen thanks are due for the preparation of material, and to Mr. Burbank, who so generously gives both his plants and his time for the forwarding of the study of plant hybrids, acknowledgment is especially and gratefully made. Acknowledgment should also be made to the directors of Hopkins Seaside Laboratory, Pacific Grove, California, for the use of a research-room during the summer of 1907, and to the Carmel Development Company, Carmelby-the-Sea, California, who provided a Laboratory which was used during the summer, 1908.

*Year Book, Carnegie Institution of Washington, 1907. 


\section{TRICHOMES OF OENOTHERA LAMARCKIANA $\times$ OENOTHERA CRUCIATA AND OF THE PARENTAL LINES.}

Three types of trichomes are found in both Oenothera lamarckiana and Oenothera cruciata, and each species bears all three types (fig. 1). These are awn- or awl-shaped, club-shaped, and pear-shaped, and are referred to as such in the following account of them. A11 of the trichomes are unicellular.

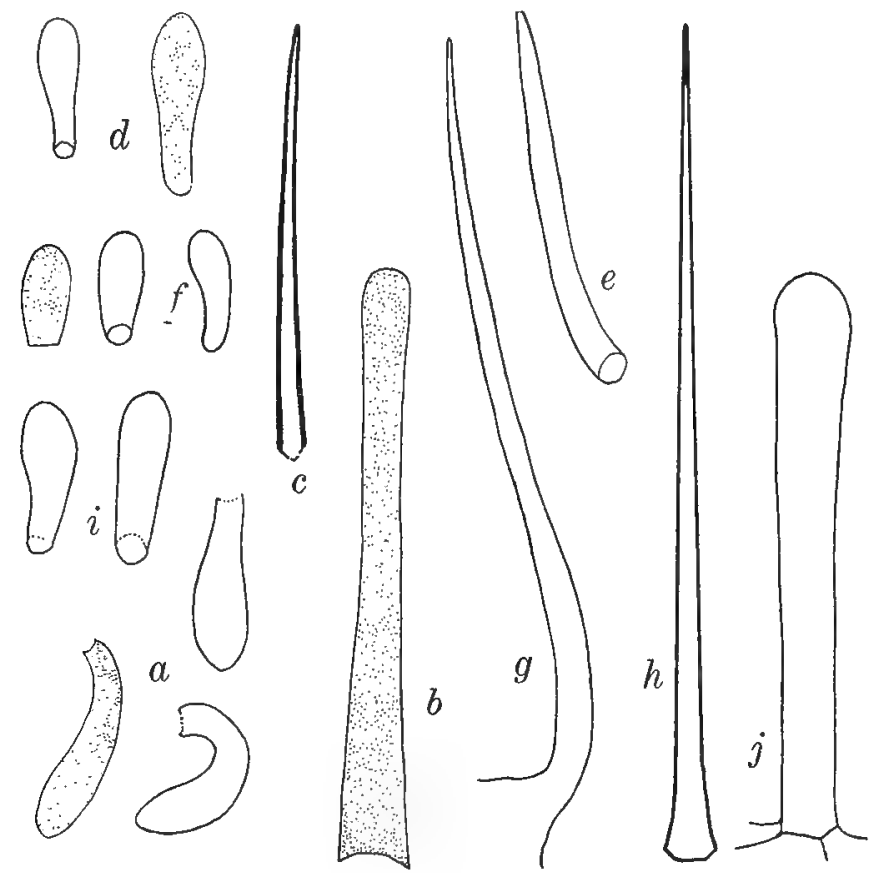

FIG. 1. $-a$ to $d$, Oenothera lamarckiana; $e$ to $g, 0$. cruciata; $h$ to $j, 0$. lamarckiana $\times$ cruciala. $a$, pear-shaped trichomes from the stem $(\times 535) ; b$, club-shaped trichome from the veins, lower leaf-surface $(X 535) ; c$, awn-sbaped trichome from ventral surface of leaf, between veins $(X 84) ; d$, pear-shaped trichomes from ventral surface of leaf, between veins ( $\times 362)$; $e$, awn-sbaped trichome from between the veins, ventral leaf-surface $(\times 362) ; f$, pear-shaped trichomes from ventral surface of leaf, between veins; $g$, awn-shaped trichome from stem $(\times 362) ; h$, giant awn-shaped trichome from capsule $(\times 84) ; i$, pear-shaped trichomes from ventral leaf-surface $(\times 535) ; j$, club-shaped trichome from capsule $(\times 362)$.

The awn-shaped trichomes of the older leaves are lifeless. They vary in length to a marked degree, and in extreme instances range from $71.4 \mu$ to $1.8 \mathrm{~mm}$., although for the most part the differences in length lie between $200 \mu$ and $1.00 \mathrm{~mm}$. 
The club-shaped trichomes, as well as the pear-shaped ones, are glandular, and hence living. Both are less variable in size than the awn-shaped trichomes and both have lengths characteristic of each species. The leading characters of the glandular trichomes are sufficiently shown in fig. 1 and do not require further description in this place.

\section{OENOTHERA LAMARCKIANA.}

In the pure parent Oenothera lamarckiana, the three kinds of trichomes above described are to be found on the lower surface of the leaves, on the stem, and on the capsule. The variation of the awn-shaped trichome, which was referred to above, may be shown by the following measurements, expressed in $\mu$ : ventral surface of the leaf, 163.8, 168, 191.2, 202.6, 222.2, $223.1,244.6,248.8,265.6,306.6,344.4,399.0,420.4$. The trichomes above measured were selected at random; the following measurements are of trichomes which were in the region of the veins of the leaf, expressed in $\mu$ : $126.0,231.0,239.4,252.0,252.0,336.0,399.0,420.0,453.6$. On the stem the measurements were $126.0,159.6,176.0,269.6,387.2,440.0,721.6$, $756.8,844.8,880.0,915.0,1144.0,1196.8$. On the capsule these trichomes were less numerous but were all relatively long, as the following measurements, in $\mu$, indicate, $844.8,897.6,915.2,922.8,968.0,1003.6,1073.6$, 1073.6, 1144.0, 1196.8 .

The club-shaped trichomes occur also on the ventral surface of the leaves, on the capsule, and on the stem. This type of trichome is more uniform in size in any given area, as between the veins or on the veins of the leaf, than the awn-shaped trichome, and also the trichomes of different areas are more nearly the same size than those of the other (awn-shaped) type. This is also true, and perhaps more consistently so, of the pear-shaped trichomes, the measurements of which will be given below, from which circumstance a study of them as inheritable qualities is of value. The following measurements, in $\mu$, were made of the club-shaped trichomes taken from the lower leaf-surface and between the veins: 168.0, 176.4, 180.6, $184.8,189.0,189.0,197.4,201.6,210.0,227.0,231.2,231.0,247.8,252.0$, 253.0. Trichomes on the veins measured as follows, in $\mu$ : 168.0, 168.0, 180.6, 189.0, 191.2, 201.6, 205.6, 211.0, 211.0, 231.0, 252.0. Club-shaped trichomes on the stem had the following lengths, in $\mu: 131.2,172.2,176.4$, $180.6,180.6,201.6,210.0,210.0,222.6,248.8$. On the capsule these trichomes measured as follows, in $\mu$ : 155.4, 163.8, 176.4, 189.0, 205.6, 211.0, $222.6,231.0,235.2,252.0,252.0$. The average lengths of the club-shaped trichomes for the given areas are as follows: lower surface of leaf, on vein, $200.08 \mu$; between veins, $209.2 \mu$; on stem, $193.4 \mu$; on capsule, $208.5 \mu$.

Pear-shaped trichomes were studied on the ventral surface of leaves, on the stem, and on the capsule. The following measurements, in $\mu$, give the 
lengths of these trichomes for the different areas noted. Ventral surface of leaf, between the veins: $37.8,37.8,37.8,39.9,42.042 .0,42.0,42.0,42.0$, $46.2,46.2,46.2,50.4,50.4,50.6$; on the veins, 37.8, 42.0, 46.2, 50.4, 50.4, $54.6,54.6,54.6,54.6,54.6,54.6,63.0,63.0,67.2$; on the stems: $37.8,37.8$, $39.9,39.9,42.0,42.0,26.2,46.2,46.2,50.4,54.6,54.6,163.0,67.2,67.2$. The pear-shaped trichomes were not so abundant on the capsules as elsewhere; 9 trichomes from the capsule measured as follows, in $\mu: 37.8,46.2,48.3$, $50.4,65.6,58.8,58.8,58.8,58.8$. The averages in length for these hairs are: (1) between the veins, on the lower surface of the leaf, $43.5 \mu$; (2) on the veins, $53.4 \mu$; (3) on the stem, $54 \mu$; and (4) on the capsule, $52.5 \mu$.

In comparing the relative development of the two kinds of glandular trichomes on equivalent areas we find that those on the stem are rather small and that those on the capsule and on the veins of the leaf are relatively large, but the relation of the size of the two trichomes to the given areas is not strictly consistent. For example, the smallest pear-shaped trichomes are to be found between the veins on the lower surface of the leaf, while it is in such areas that the longest club-shaped trichomes occur. This relation is shown in table 1 .

\section{TABLE 1.-Relative lengths of the club-shaped and the pear-shaped trichomes of Oenothera lamarckiana.}

\begin{tabular}{|c|c|c|}
\hline Where found. & $\begin{array}{c}\text { Club- } \\
\text { shaped. }\end{array}$ & $\begin{array}{c}\text { Pear- } \\
\text { shaped. }\end{array}$ \\
\hline 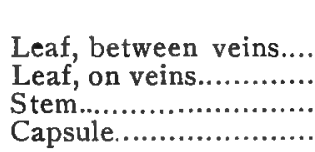 & $\begin{array}{c}\mu \\
209.2 \\
200.8 \\
193.4 \\
208.5\end{array}$ & $\begin{array}{c}\mu \\
43.9 \\
53.4 \\
50.3 \\
62.5\end{array}$ \\
\hline
\end{tabular}

OENOTHERA CRUCIATA.

The three forms of trichomes which are to be found in Oenothera lamarckiana are present in cruciata also (fig. 1). In form and in other characters, the trichomes of cruciata are like those of the other species, only they are consistently smaller.

The awn-shaped trichomes, upon the lower surface of the leaves and between the veins, are relatively uniform in length and usually straight. The extremes in length which were observed were $71.4 \mu$ and $131.4 \mu$. On the veins the trichomes are somewhat more variable and range in length between $71.4 \mu$ and $399 \mu$. Mixed with the shorter awn-shaped trichomes there are on the stem numerous giant trichomes of the same character, save as to size. These were seen as long as $1.3 \mathrm{~mm}$. The giant trichomes only, of this general type, were found on the capsule, where they attained a length as great as $1.8 \mathrm{~mm}$. 
The club-shaped trichomes were not so abundant as in the other pure species. None were found on the lower surface of the leaf, either upon or between the veins, and none on the stem. The following measurements, in $\mu$, were made of club-shaped trichomes on the capsule: 96.6, 121.8, $134.4,134.4,147.0,163.8,168.0$. The average length was $138.0 \mu$.

The pear-shaped trichomes occur on the lower surface of the leaves, on the stem, and on the capsule. Other than being somewhat smaller in size they are like those of Oenothera lamarckiana. Trichomes between the veins on the lower surface of the leaves were found to have the following lengths, in $\mu: 23.1,25.2,25.2,29.4,29.4,29,4,33.6,33.6,33.6,33.6,35.7,35.7,39.9$, $39.9,42.0$. The trichomes between the veins average $32.5 \mu$ in length. On the veins the trichomes gave the following measurements, in $\mu: 25.2,31.6$, $33.6,33.6,33.6,33.6,35.7,37.8,37.8,37.8,37.8,39.9,42.0,42.0,46.2$. The average length of the pear-shaped trichomes on the veins was found to be $36.5 \mu$. The following measurements, in $\mu$, were derived from trichomes on the stem: $29.4,29.4,29.4,31.5,33.6,33.6,33.6,33.6,33.6$, $33.6,33.6,35.7,35.7,35.7$. The trichomes on the stem average $33.4 \mu$ in length. On the capsule the measurements, in $\mu$, were: $27.3,29.4,29.4$, $31.5,31.5,31.5,33.6,33.6,33.6,33.6,33.6,35.7,37.8,37.8,3.78$. The pearshaped trichomes of the capsule average $33.2 \mu$ in length. The relation of the pear-shaped and club-shaped trichomes to the areas where they occur is shown in table 2 .

\section{TABLE 2.-Relation of the trichomes of Oenothera cruciata to the position on the plant where found.}

\begin{tabular}{|c|c|c|}
\hline Where found. & $\begin{array}{l}\text { Club- } \\
\text { shaped. }\end{array}$ & $\begin{array}{c}\text { Pear- } \\
\text { shaped. }\end{array}$ \\
\hline - Leaf, between veins... & $\stackrel{\mu}{\text { Absent }}$ & $\begin{array}{l}\mu \\
32.5\end{array}$ \\
\hline Leaf, on veins ............. & Absent & 36.5 \\
\hline Stem $\ldots \ldots \ldots \ldots \ldots \ldots \ldots$ & Absent & 33.4 \\
\hline Capsule .......................... & 138.0 & 33.2 \\
\hline
\end{tabular}

In comparing the lengths of the pear-shaped trichomes of the two species we find that those of Oenothera cruciata are smaller wherever found than those of Oenothera lamarckiana, but that in both species the trichomes are of variable length. The longest trichomes, with hardly an exception, occur in the region of the veins of the leaf, and the shortest occur between the veins of the leaf. In both species, also, the trichomes of the stem and of the capsule are, as a rule, intermediate in length. The absence of clubshaped trichomes from the leaf and the stem of Oenothera cnuciata precludes a comparison of this trichome in the two plants, but it is significant that the trichomes of this type on the capsule of Oenothera cruciata are smaller than 
those on the capsule in the other species, as might be expected from a comparison of the pear-shaped trichomes. The awn-shaped trichomes are so irregular in their variation that a comparison of them would be meaningless.

\section{OENOTHERA LAMARCKIANA $\times$ OENOTHERA CRUCIATA.}

The three sorts of trichomes which occur in both pure parents, the awnshaped, the club-shaped, and the pear-shaped, are to be found in the hybrid also (fig. 1). The trichomes, except as to size, are apparently like those of the parents; they are intermediate in size. The figures show the leading characters of the trichomes and a further description of them in this place is unnecessary.

The awn-shaped trichomes on the ventral surface of the leaf, between the veins, measure from $84.0 \mu$ to $323.0 \mu$ long; those on the veins range from $84.0 \mu$ to $1073.6 \mu$ in length. Awn-shaped trichomes from the stem are from $96.6 \mu$ to $1214.4 \mu$; those on the capsule are all of the long kind and measure from $915.2 \mu$ to $1284.8 \mu$ in length.

The club-shaped trichomes were not seen on the lower surface of the leaves or on the stem, but were abundant on the capsule. The following measurements, in $\mu$, were made of such trichomes from the capsule: 163.8 , $168.0,180.6,193.2,201.6,205.8,210.0,222.6,239.4,243.6$. These trichomes average $202.8 \mu$ in length.

The pear-shaped trichomes occur on the lower surface of the leaf, on as well as between the veins, on the stem but not on the capsule. Trichomes from the lower surface of the leaf, between the veins, measured as follows, in $\mu: 29.4,29.4,29.4,31.6,33.6,33.6,35.7,35.7,37.8,37.8,37.8$, $42.0,43.2$; on the veins, $33.6,33.6,35.7,35.7,37.8,37.8,42.0,42.0,42.0$. $42.0,44.1,44.1,46.2,50.4$. The average length of the former is $34.9 \mu$, of the latter is $41.3 \mu$. The following measurements, in $\mu$, were obtained from trichomes on the stem: $33.6,33.6,35.7,35.7,37.8,37.8,42.0,42.0$, $42.0,42.0,42.0,44.1,44.1,46.2,50.4$. The average length of the pearshaped trichomes on the stem was found to be $40.6 \mu$.

Table 3 gives the relative lengths of the trichomes of Oenothera lamarckiana $\times$ Oenothera cruciata.

\section{TABLE 3.-Relative lengths of club-shaped and pear-shaped trichomes of Oenothera lamarckiana $\times$ Oenothera cruciata.}

\begin{tabular}{|c|c|c|}
\hline Where found. & $\begin{array}{l}\text { Club- } \\
\text { shaped. }\end{array}$ & $\begin{array}{c}\text { Pear- } \\
\text { shaped. }\end{array}$ \\
\hline $\begin{array}{l}\text { Leaf, between veins..... } \\
\text { Leaf, on veins ............ } \\
\text { Stem ......................... } \\
\text { Capsule................... }\end{array}$ & $\begin{array}{r}\mu \\
\text { Absent } \\
\text { Absent } \\
\text { Absent } \\
202.8\end{array}$ & $\begin{array}{r}\mu \\
34 \cdot 9 \\
4 I \cdot 3 \\
40.6 \\
\text { Absent }\end{array}$ \\
\hline
\end{tabular}




\section{COMPARISON OF TRICHOMES OF THE OENOTHERAS.}

Upon comparing the extremes in length of the trichomes of the hybrid with those of the parents we find (1) that the shortest pear-shaped trichome in Oenothera cruciata is $23.1 \mu$; the shortest in Oenothera lamarckiana, on the other hand, is $37.8 \mu$, while the shortest in the cross is $29.4 \mu$, and (2) that the longest pear-shaped trichome in Oenothera lamarckiana is $67.2 \mu$, the longest in the hybrid is $50.4 \mu$, and in Oenothera cruciata is $46.2 \mu$. In every instance the shortest pear-shaped trichomes occur on the lower surface of the leaf and between the veins, although in Oenothera lamarckiana short ones occur also on the other areas; the longest are to be found on the veins, although in the hybrid long ones may occur on the stem as well. As will appear repeatedly in this study, this relation of the length of trichome to area where found is so consistent in all plants that there may be some common underlying cause, as, for example, nutritive conditions, which induces the differentiation. At any rate, the variation is constant and must be taken into account in the comparison of the trichomes of related forms.

Reference to tables 1, 2, and 3 will show that in every instance where analogous trichomes from similar areas are compared, those of the hybrid are intermediate in size, those of Oenothera lamarckiana are larger, and those of Oenothera cruciata are smaller. In every instance also, the trichomes of the hybrid are somewhat less than one-half the sum of the other; that is, they are not average in measurement. In such hybrids as the above, when both parents possess identical, or practically identical, trichomes, whose sole apparent difference is that of size, we would perhaps expect such a result. This would be based on one of at least two grounds: First, either that the trichomes of the hybrid would represent the equal influence of both parents, as McFarlane* showed long ago for several hybrids; or second, if there was inconsistent working of the law of dominance so that a portion of the trichomes would show reversion to one and a portion to the other parent and the third portion be indeterminate in this regard, the average of the whole would be intermediate. So far as the present studies would indicate, there is no clear proof that reversion may not occur as stipulated in the second alternative, since 60 per cent of the pear-shaped trichomes of Oenothera lamarckiana come within the range of size exhibited by these types in the hybrid, and 80 per cent of the pear-shaped trichomes of Oenothera cruciata are within the range of size of those of the hybrid. But it seems more probable, from the general intermediate condition of the hybrid, that the trichomes may each also show the influence of each parent in approximately equal measure.

*A comparison of the minute structure of plant hybrids with that of their parents, and its bearing on biological problems. Trans. Roy. Soc. Edinb., 37: 203, 1892. 
A study of the range of variation of the pear-shaped trichomes shows that those of the hybrid in nearly every instance are less variable than those of either parent. The equations in table 4, which are numbers based on the extreme lengths of the trichomes, present the relative variability in a graphic manner.

TABLE 4.-Comparative variability of pear-shaped trichomes of the Oenotheras.

\begin{tabular}{|c|c|c|c|}
\hline Where found. & $\begin{array}{l}\text { O. lamarck- } \\
\text { iana. }\end{array}$ & $\begin{array}{l}\text { O. lamarckiana } \\
\times \text { O. cruciata. }\end{array}$ & O. cruciata. \\
\hline 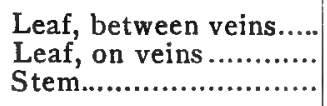 & $\begin{array}{l}149 \\
177 \\
167\end{array}$ & $\begin{array}{l}146 \\
150 \\
150\end{array}$ & $\begin{array}{l}181 \\
183 \\
121\end{array}$ \\
\hline Average... & 164 & 148 & 164 \\
\hline
\end{tabular}

The distribution of the trichomes shows the influence of both parents in an unequal degree. The awn-shaped trichomes are found on all areas, $i . e .$, on leaf, stem, and capsule, but the club-shaped and pear-shaped trichomes are variously distributed. The former occurs on all of the areas in Oenothera lamarckiana, but only on the capsule in Oenothera cruciata and the hybrid. The distribution of the pear-shaped trichomes is much more general and uniform; they occur on the leaf and the stem in parents and the hybrids, and on the capsule in Oenothera cruciata, but are not present on the capsule in the cross, and only sparingly so on the capsule in Oenothera lamarckiana. Where there are several kinds of trichomes present the distribution of each kind in parents and hybrid offspring must be compared in order to derive any exact knowledge of the influence of the parents or the behavior of the pubescent covering throughout the generations of hybrids studied. It is doubtful whether the quality of hairiness in plants can rightly be considered a "unit-character," and the analysis must be carried yet further. 


\section{TRICHOMES OF PAPAVER HYBRIDS AND THE PURE SPECIES.}

\section{TRICHOMES OF THE PURE SPECIES.}

The three species of Papaver which were studied have only one type of trichome, which is multicellular, awn-shaped, and usually slightly curved (fig. 2). The trichomes may attain a length so great as $7.0 \mathrm{~mm}$. (Papaver orientale), although they usually are shorter than this.
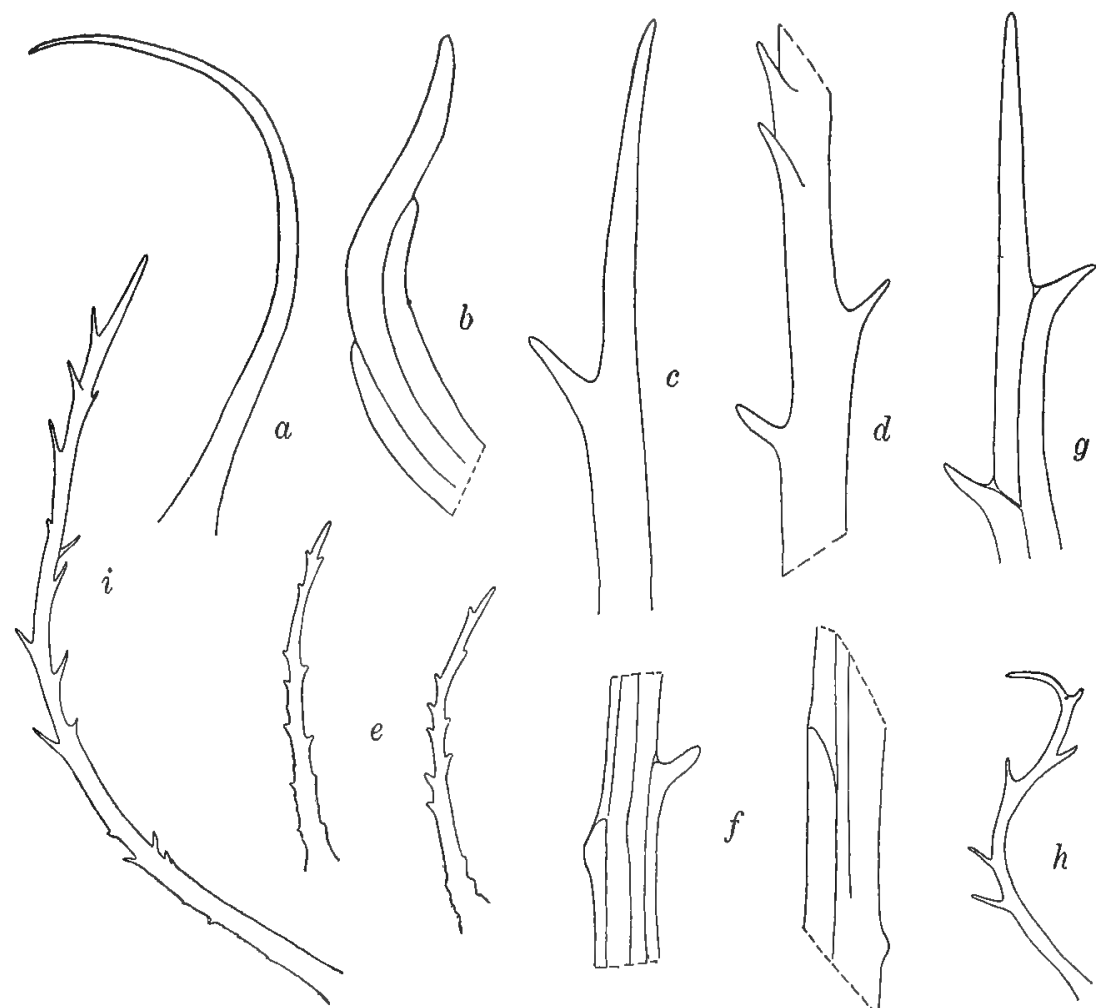

FrG. 2.-Trichomes of Papaver pure lines and hybrids. Papaver somniferum: $a$, multicellular trichome from young stem $(\times 44)$; $b$, detail of tip of trichome, showing appressed distal ends of the superficial cells ( $\times 362)$. Papaver orientale: $c$, tip of trichome, to show the projection of distal ends of superficial cells $(\times 362)$; $d$, detail from middle portion of tri. chome $(\times 362)$. Paprever pilosum: $e, 2$ trichomes, semi-diagrammatic, to illustrate the projection of superficial cells $(\times 84)$. Papaver somniferum $\times P$. orientale: $f$, detail from middle part of a typical trichome, to show the inconsistent behavior of superficial cells. only a portion of which project $(362) ; g$, tip of trichome $(X 362)$. Papaver somniferum $\times \boldsymbol{P}$. pilosum: $h$ and $i$, trichomes from a leaf, illustrating relatively prominent projections of superficial cells $(\times 81)$.

The trichomes have a curious structure, unlike any other encountered in the course of this investigation. Their growth appears to be indeterminate. As a direct result of this character the length of the trichomes is very unequal, so that comparative study of them from this standpoint would be without value. The trichomes end in a single much-elongated cell 
(fig. 2, b). Somewhat away from the tip there are 2 cells in cross-section, still further there are 3 cells, and the number of cells of the cross-section increases as one goes towards its base. At the base the trichome expands suddenly, so that in longitudinal section it is conical. A11 of the cells of the trichome are elongated in a direction parallel to its longer axis. The increase in length takes place at the tip of the trichome, where new cells are cut off by somewhat oblique walls. Growth in diameter appears to occur by longitudinal divisions of the inner cells, but the exact sequence of these divisions was not studied. The trichomes of the three species are similar in form and size, but they are unlike in quality of roughness. In Papavcr orientale and Papaver pilosum the distal ends of the superficial cells project beyond the general surface of the trichome and turn out at a rather acute angle (fig. 2, $c, d$, and $e$ ). In Papaver somniferum, however, these cells did not extend beyond the general surface, with the effect that the trichomes of this species are smooth (fig. 2,a).

The leaves, stem, and flower-stalk of Papaver orientale and of Papaver pilosum are well clothed with trichomes; but Papaver somniferum is practically glabrous, as only a few trichomes were observed on the flower-stalk, and none on stem or leaf.

\section{PAPAVER SOMNIFERUM $\times$ PAPAVER ORIENTALE.}

The leaves and the stem of the hybrid are well covered with trichomes, which in size and in form resemble those of Papaver orientale, but in certain regards they are unlike the trichomes of that species. They, also, are different from the trichomes of Papaver somnifenm, and in each instance the variance lies in the character of the peripheral cells. The distal ends of the peripheral cells, which in the seed parent are suppressed, but which project with much regularity in the pollen parent, in the hybrid are extremely variable in their behavior. In some instances they do not project at a11, in others the projection is well marked, perhaps accentuated, and frequently a middle condition was noted (fig. $2, f$ ). In this particular, therefore, the hybrid is fairly intermediate and exhibits the influence of both parents.

\section{PAPAVER SOMNIFERUM $\times$ PAPAVER PILOSUM.}

The hybrid Papaver somniferum $\times$ Papaver pilosum is especially well covered with trichomes which closely resemble those of the other Papaver hybrid studied. That is, in one character, namely, that of the surface of the trichomes, they are intermediate between the pure parents. The projections of the superficial cells are, if anything, even more irregular than in the other hybrid (fig. $2, h$ and $i$ ). In some instances the projections are suppressed entirely, in others they are exaggerated and the trichome has the appearance of bearing branches, but an intermediate condition also occurs. This variation is suggested, but nowise adequately shown, in the accompanying sketches. 


\section{TRICHOMES OF SOLANUM VILLOSUM $\times$ SOLANUM GUINENSE AND OF THE PURE SPECIES.}

\section{SOLANUM VILLOSUM.}

There are 2 , or possibly 3 , kinds of trichomes in Solanum villosum, all of which are multicellular and glandular (fig. 3, $a, b$, and $c$ ). These for convenience are in this paper called the awn-shaped, the giant awnshaped, and the big-headed trichomes. The trichomes were observed on the stem, on the lobes of the calyx, and on the ventral surface of the leaves. On the stem and on the calyx all 3 types occurred, with no apparent choice of position, but on the leaf the distribution was as follows: only the awn-shaped trichomes occurred between the veins; all were found on the veins.
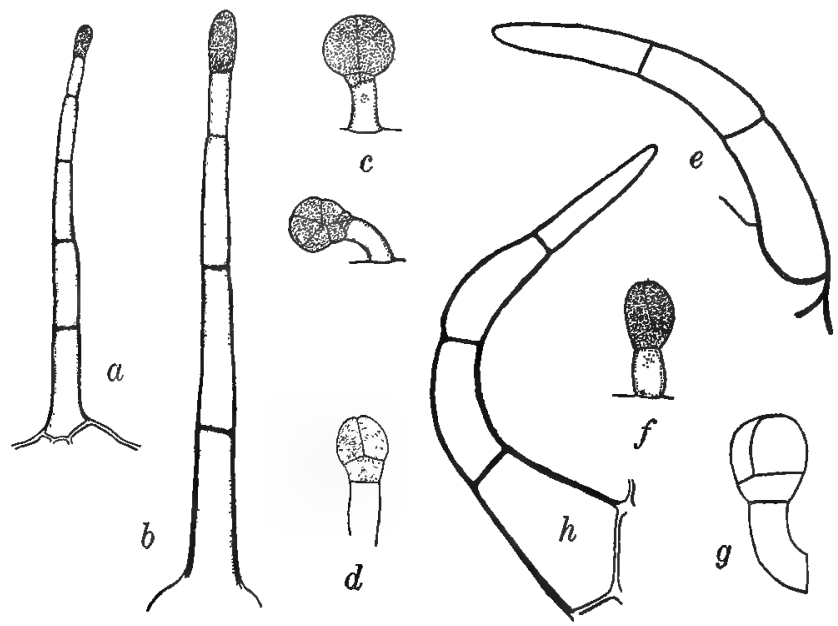

FIG. 3.-Trichomes of Solanum pure species and hybrids. Solanum villosum: $a$, awn-shaped secreting trichome from leaf, region of veln; $b$, giant awn-shaped secreting trichome from region of midrib, ventral leai-surface; $c$, big-headed glandular trichomes from young stem. Solanum guinense: $d$, big-headed glandular trichomes from ventral leaf-surface; $e$, awn-shaped non-secreting trichome. Solanum villosum $\times$ S. guinense: $f$, big-headed glandular trichome from ventral surface of leaf; $g$, big-headed glandular trichome. (For size of trichomes see text; reduced one-half.)

The awn-shaped trichomes are composed of a single row of cells, usually 5, which constitute the stalk, and a single terminal cell, which is somewhat swollen and contains coarsely granular matter. The stalk-cells are provided with a delicate protoplasmic lining and are hyaline. They measure from $176 \mu$ to $352 \mu$ in length, with the greatest number about $193 \mu$ long. 
The giant awn-shaped trichomes are different from the awn-shaped ones mainly in the quality of size; they measure from $792 \mu$ to $1.4 \mathrm{~mm}$. No trichomes were observed of the awn-shaped type which measured longer than the longest awn-shaped trichomes, $352 \mu$, or shorter than the shortest giant awn-shaped trichomes, $792 \mu$, for which reason the giant awn-shaped trichomes ought probably to be considered a distinct type.

The big-headed trichome is somewhat curved, so that it is frequently closely appressed to the surface. In structure it is composed of a stalk of 2 cells and a head of an undetermined number of cells, probably 4 . The stalk-cells are hyaline; the cells composing the head are densely filled with a coarse granular substance. These trichomes measure from $63 \mu$ to $75.6 \mu$ in length.

\section{SOLANUM GUINENSE.}

Two types of trichomes were observed in Solanum guinense, of which one is glandular and similar to the big-headed trichome of Solanum villosum, and the other is not glandular and is unlike any trichome seen in the other species (fig. 3,e).

The trichomes were found mainly on the veins of the ventral surface of young leaves and on young stems; the older stems and older leaves were usually glabrous.

The big-headed secreting trichomes were either straight or mostly curved and appressed to the surface. 'They measure from $67.2 \mu$ to $71.4 \mu$ in length. As in structure, size, and general appearance these trichomes are similar to the analogous ones in Solanum villosum, a further description of them is unnecessary.

The non-secreting trichome (the uncommon type) is broadly awn-shaped, is usually curved, and more or less closely appressed to the surface. It is composed of 3 or 4 cells, which rest on a multicellular base. The trichomes measure from $239.4 \mu$ to $378.0 \mu$ in length.

\section{SOLANUM VILLOSUM $\times$ SOLANUM GUINENSE.}

Two types of trichomes were observed in the hybrid Solanum. These were in all respects like those of the species Solanum guinense, and consequently were the big-headed secreting trichome and the awn-shaped nonsecreting trichome (fig. $3, e$ and $f$ ). The trichomes are on the ventral leafsurface, where they are confined to the veins. The big-headed trichomes measure from $67.2 \mu$ to $80 \mu$ in length, and the awn-shaped trichomes from $252.2 \mu$ to $316.8 \mu$ in length.

The account above given is from a study of first-generation plants. About a dozen second-generation plants were examined also and a condition quite like that observed in the first generation was found. Measurements of the big-headed secreting trichomes of second-generation hybrids showed that they ranged from $63.0 \mu$ to $71.4 \mu$ on the leaves, and $71.4 \mu$ to 
$75.6 \mu$ on the stem. The non-secreting awn-shaped trichomes measured from $218.8 \mu$ to $316.8 \mu$ in length.

The general relation of the trichomes of the hybrid and the pure lines of Solanum are given graphically in table 5 .

TABLE 5.-Comparison of the trichomes of Solanum villosum $\times$ Solanum guinense with those of the pure species.

\begin{tabular}{|c|c|c|c|}
\hline Kind. & S. villosum. & The hybrid. & S. guinense. \\
\hline Awn-shaped, glandular....... & I $76 \mu$ to $352 \mu \ldots \ldots$ & Absent............... & Absent. \\
\hline Giant awn-shaped... ............. & $792 \mu$ to $1.4 \mathrm{~mm}$... & Absent................ & Absent. \\
\hline Big-headed................................. & $63 \mu$ to $75.6 \mu \ldots$. & $\begin{array}{l}67.2 \mu \text { to } 80 \mu \ldots \\
*(63 \mu \text { to } 71.4 \mu) \ldots \\
*(71.4 \mu \text { to } 75.6 \mu)\end{array}$ & $67.2 \mu$ to $71.4 \mu$. \\
\hline Awn-shaped, not glandular.. & Absent................. & $\begin{array}{l}252.2 \mu \text { to } 316.8 \mu \\
*(218.8 \mu \text { to } 316.8 \mu)\end{array}$ & $239.4 \mu$ to $378 \mu$ \\
\hline
\end{tabular}

*The numbers in parenthesis refer to hybrids of the second generation.

The data at hand are not sufficient either in amount or in kind to permit the tracing of the influence of the pure lines on the hybrid offspring. This much is apparent, however: the trichomes of the non-secreting awn-shaped type which the hybrid inherits from Solanum guinense are of full, not of half size, as MacFarlane found in certain hybrids investigated by him where unilateral inheritance also obtained.* 




Dorsal surface of leaves of Juglans nigra, which was growing near the Sebastopol, California, ranch of Luther Burbank. The leaves were selected to show the extreme variation in size and number of leaflets, and size of leaves. The basal pair of leaflets in the figure to the right are only partly shown. One-third natural size. 
$\because$ 


\section{PURE SPECIES AND HYBRIDS OF JUGLANS.}

\section{LEAVES OF THE PURE SPECIES.}

The English walnut and the eastern black walnut are common in cultivation in and around Santa Rosa, where they grow thriftily. The California walnut is native at Santa Rosa and is also extensively cultivated as a shade tree in the city, as elsewhere throughout the State. Material for the study of the California walnut (Juglans californica) and the English walnut (Juglans regia) was obtained from trees 16 and 13 meters in height, respectively, which are growing on the grounds of two of Mr. Burbank's neighbors in Santa Rosa. Material of the third type (Juglans nigra) was collected from a second-growth tree, about 10 meters high, which was growing by the roadside between the town of Sebastopol and the Burbank ranch near that place. The collections were made in May, 1907, and May, 1908. It is not known whether the trees from which the collections of material were made were the actual parents of the original crosses or not. It is assumed in this study that the alternative is the case.

\section{JUGLANS CALIFORNICA.}

The leaves of Juglans californica bear from 9 to 10 pairs of leaflets and 1 terminal one (plate 1), which is frequently the smallest one of the leaf. The leaflets are ovate lanceolate and taper gradually to the tip; the base is abrupt and even cordate; that of the terminal leaflet is attenuate. They are somewhat roughened on the upper surface and are irregularly serrate, with rather obtuse teeth. A close study of the leaflets would show considerable variation, especially in size and in form, although the extent of the variation has not been especially examined.

In May, 1907, when the first collection of leaves, which were exclusively studied, was made, they were fresh-green and free from fungus; in the following September, when the photographs were made, the upper surface was badly infested with a black fungus which to an extent shows in the plate.

\section{JUGLANS NIGRA.}

The leaves of Juglans nigra are extremely variable, particularly as to size and number of leaflets, which number from 6 to 10 or more pairs and which are irregularly disposed on the rachis (plate 2). In addition to the variation of the leaves as a whole, the leaflets, also, are far from uniform and in outline range from nearly cuneate to ovate; the terminal one is usually the smallest. They taper gradually to an attenuated apex. The bases are abrupt, but usually they are not cordate. The leaflets are serrate, with fairly regular and sharply pointed teeth; the ventral surface, in texture, is generally smooth. 


\section{JUGLANS REGIA.}

The leaves of Juglans regia are composed of from 2 to 3 pairs of leaflets and a terminal one. The leaflets usually grade in size from the basal ones to the terminal one, which is largest. They are broadly ovate and taper rather abruptly to the apex, as well as to the base. The base of the terminal leaflet is somewhat attenuated. The margin of the leaflets is entire; the upper surface of the leaflets is minutely roughened or nearly smooth, with the veins projecting somewhat above it (plate 3 ).

Table 6 presents in a condensed form the leading characters of the leaves of the 3 species of Juglans.

TABLE 6.



TRICHOMES OF THE PURE SPECIES.

There are 4 , or perhaps 5 kinds of trichomes in the pure species of Juglans studied, all of which are found in each of them, which are transmitted kind for kind to the hybrids, so that all types are to be found in the cross in the first and, so far as observed, in the second and the third generations also.* The trichomes will be called (1) awn-shaped, which may form groups which constitute stellate trichomes; (2) disk-shaped; (3) long secreting trichomes, apparently of two kinds; and (4) short secreting trichomes. All of the trichomes, except the awn-shaped, are glandular (figs. 4, 5, 6, 7, and 8).

The trichomes are distributed in time and in space in a manner which is fairly consistent and characteristic. In the youngest leaves the most abundant trichomes are the awn-shaped ones. In old leaves, although not plentiful, the short secreting trichomes may be the only trichomes, or nearly the only ones, to be found. In what may be called the leaves of middle age, all of the trichomes occur, none perhaps predominating. A11 the glandular trichomes are to be found on both surfaces of the leaves, but

*In the present study observations have been confined to the trichomes of young and old leaves; only in one or two cases has the study been extended to the stem. No attempt has been made to treat the general distribution of trichomes either of the pure lines or of the hybrids. 
in the old leaves they may have disappeared from the upper surface while yet some remain on the lower (ventral) side. The awn-shaped trichomes, on the other hand, are apparently confined to the ventral surface of the leaves, whatever may be their age. In this connection an apparent adaptation, which is a nice one, is interesting to note. In old leaves the ventral (or lower) surface is protected in various ways (more especially presumably by the position) and the awn-shaped trichomes are absent; in the youngest leaves, on the other hand, the ventral surface of the leaves is the outer surface and is most exposed and at the time it is well provided with awn-shaped or stellate trichomes.

In addition to the variation in kinds of trichomes which are present at different stages of development of the leaf, or to the variation in their distribution on the leaf, either of which have only been touched in the foregoing, another factor also must be taken into account, namely, the variation of the trichomes in size which accompanies their distribution. For example, small secreting trichomes may be larger on the veins than between them, and larger on the dorsal surface than on the ventral surface of the leaf. Also, the trichomes may be larger in one stage of development of the leaf than in a subsequent stage, or there may not be this difference. Whatever may be the causes of the variation in size, the fact that the trichomes are variable makes it necessary that trichomes of analogous stages of development, as well as of analogous positions on the leaves, be compared, which has been done in all instances. These circumstances, which were noted in the other hybrids, and were observed notably in those of Oenothera, greatly extended the work, but at the same time quite as much enhanced the interest of the investigation.

\section{JUGLANS CALIFORNICA.}

Four or possibly five kinds of trichomes are to be found on both surfaces of the leaves of Juglans californica (figs. 4 and 5). These are (1) the awnshaped trichomes, (2) the disk-shaped trichomes, and (3) the long and (4) the short secreting trichomes. Of the third type there may be two kinds. The awn-shaped trichomes measure about $360 \mu$ in 1ength; the disk-shaped trichomes are closely appressed to the surface; the long secreting trichomes are $140 \mu$ more or less long, and the short secreting trichomes measure $58 \mu$ more or less in length. A more detailed description of the trichomes, their origin and development, and their variation, will be given in the following paragraphs.

The awn-shaped trichomes are more variable than the other types, and since there were no apparent causes of the variation this type of trichomes was not especially studied, either in the pure species or in the hybrids. The awn-shaped trichomes are unicellular and frequently are to be found in groups (fig. 4, a). They occur on the ventral surface only and are especially abundant on the young leaves, 
The disk-shaped trichomes are glandular and are to be found on both surfaces of the leaves (fig. $4, f$ to $n$ ).

The developmenta1 history of the trichomes was not followed in all particulars. The following are some of the definite stages:

The trichome originates as broad and squat outgrowths of an epidermal cell, from which it is early separated by a cross-wall that nearly coincides

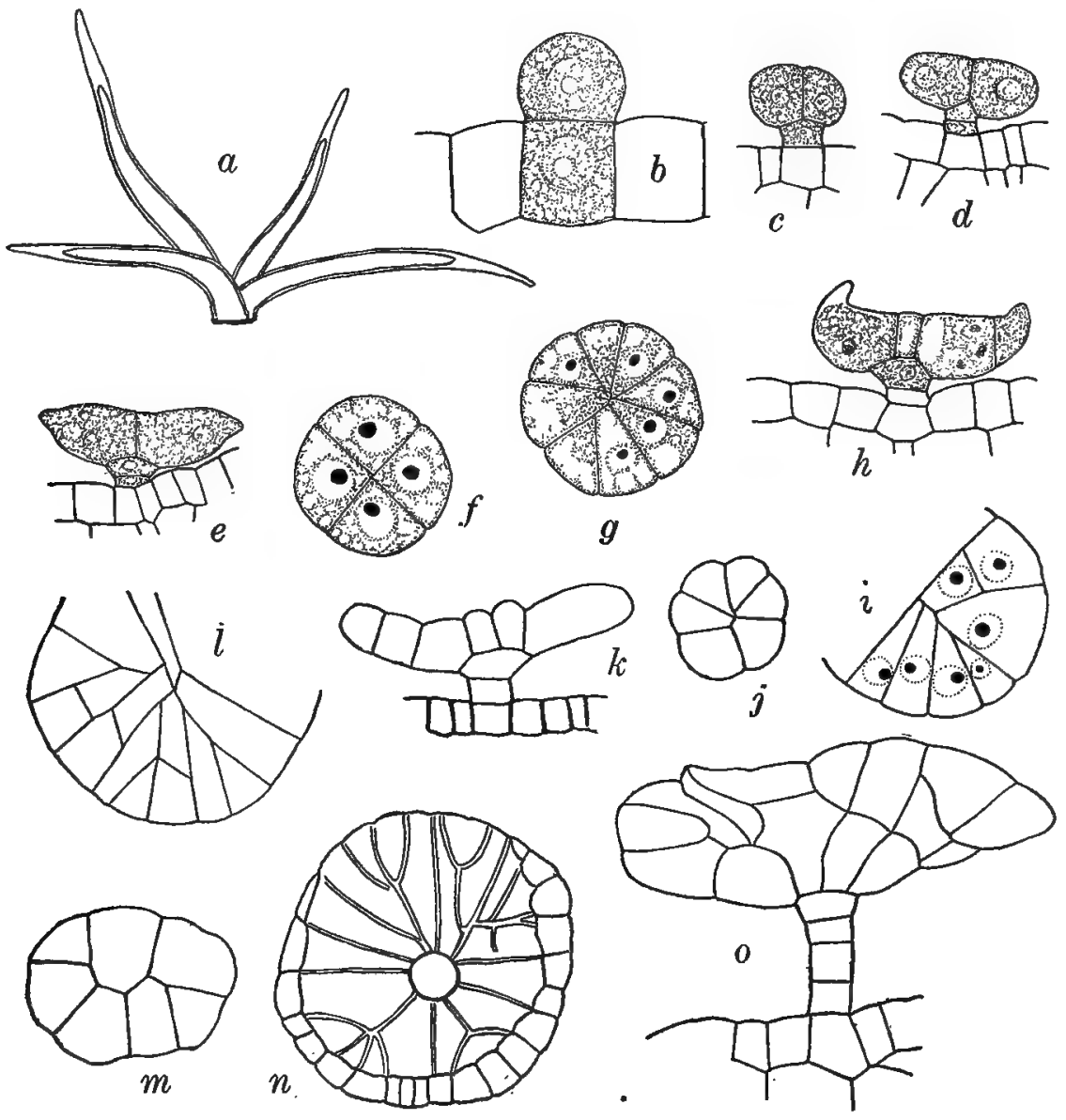

FIG. 4.-Trichomes of Juglans californica: $u$, group of awn-shaped trichomes forming a stellate trichome, leaf-surface $(\times 81)$; $b$ to $n$, various stages in the development of disk-shaped trichomes $(c, d, e, h, j$, and $l \times 535 ; f, g, i$, and $m \times 860 ; n \times 340) ; 0$, abnormal disk-shaped trichome ( $\times$ 535).

with the adjacent epidermal walls. From its first appearance as a papillate projection the disk-shaped trichome is easily distinguishable from the beginnings of the other forms. The young trichome becomes 2-celled by a transverse division which separates the stalk from the portion which will 


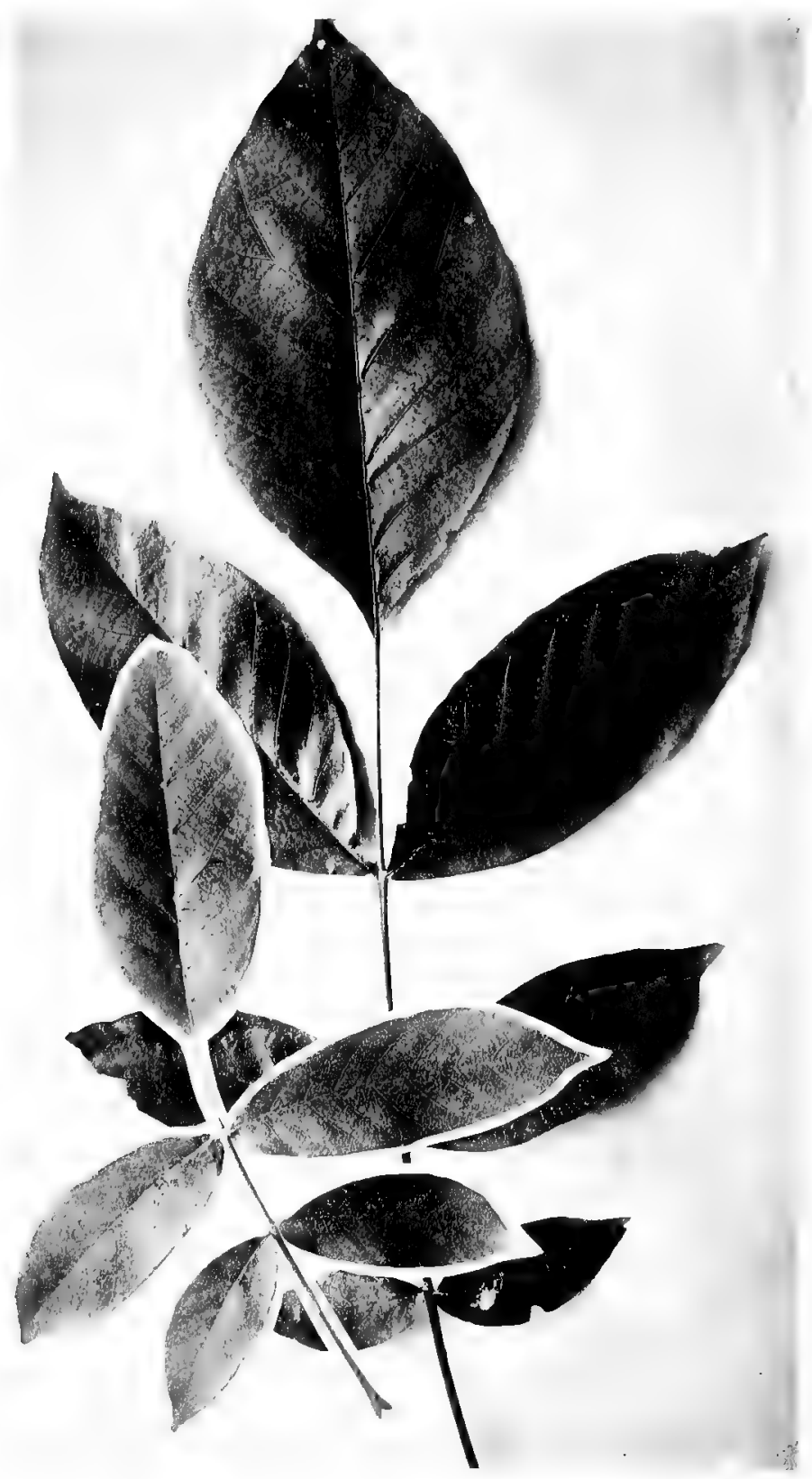

Leaves of Juglans regia, from a tree growing in Santa Rosa, California, showing extremes in size of leaves and number of leaflets. One-third natural size. 
, . 
become the head; all succeeding divisions, therefore, differentiate the two regions, namely, stalk and head. The second division is a longitudinal one in the terminal, the head-cell, which is followed by a transverse division of the stalk-cell. The stalk does not divide further in normal cells. A single monstrosity was observed however (fig. 4,o), in which the stalk had 4 cells. The subsequent cell-divisions are confined to the region of the head of the trichome. The second and third divisions of the head are by walls placed at right angles to the preceding division-wall, so that the head becomes 4 similar cells (fig. $4, f$ ).

Each quadrant is next bisected by a radial wall (fig. $4, g$ ). After this the sequence of cell-division appears not to be regular, although the octants usually undergo radial division; and this process is repeated until a head of about 32 cells is the result. Whether the mature trichome may have more than this number of cells was not determined, but in some instances the presence of cell-walls placed at right angles to the radial walls, and parallel to the long axis of the trichome, would indicate a larger number. The head of the trichome never exceeds 1 cell in thickness. At an early stage in the development of the trichome the peripheral portions of the head-cells become somewhat enlarged, so that in longitudinal section the edge of the disk is bluntly angular. This is the beginning of the rim which is a characteristic of the disk-shaped trichomes. By the more active growth of the lower portion of the more peripheral cells the rim is pushed upwards, $i . e$. , in a direction away from the surface of the leaf, until in section the head of the trichome is markedly concave (fig. $4, h$ ).

There is much variation in the depth of the concavity of the disk, as in some trichomes the tip of the trichome was quite flat, while in others the concavity was pronounced. The diameter of the heads in the mature trichomes was more uniform, as the following measurements, in $\mu$, which were made on representative trichomes selected at random, would indicate: $117,100,100,117,100,109$.

The long secreting trichomes are $126 \mu$, more or less, in length (fig. 5). The trichome takes its origin as a slender papillate projection of an epidermal cell; it is early cut off from the epidermis by a transverse wall. Subsequently it undergoes division, so that the young trichome consists of 3 cells, of which the terminal ones are the rudiment of the head of the trichome. The third wall is, as in the short secreting trichome, almost surely a transverse one in the stalk-cell. After this the sequence of cell-division was not followed, but the final result is that the head is composed of 4 equal cells, radially disposed, and the stalk is composed of 4 lineallyarranged cells. No further cell-divisions occur in this type of trichome. The terminal cells which constitute the head become densely filled with coarsely granular material; the cells of the stalk are poor in protoplasm. 
Besides this type of long secreting trichome there may be another kind with a larger number of cells in the head and also more than 4 cells in the stalk. This form of trichome, doubtful in Juglans californica, was often met in Juglans nigra, under which it will be described, and in the hybrid Juglans californica $\times$ Juglans nigra. A few trichomes with 6 stalk-cells were found in Juglans californica, one of which is shown in fig. $5, h$, but none were seen under conditions that made it possible to surely determine the number of cells in the head.
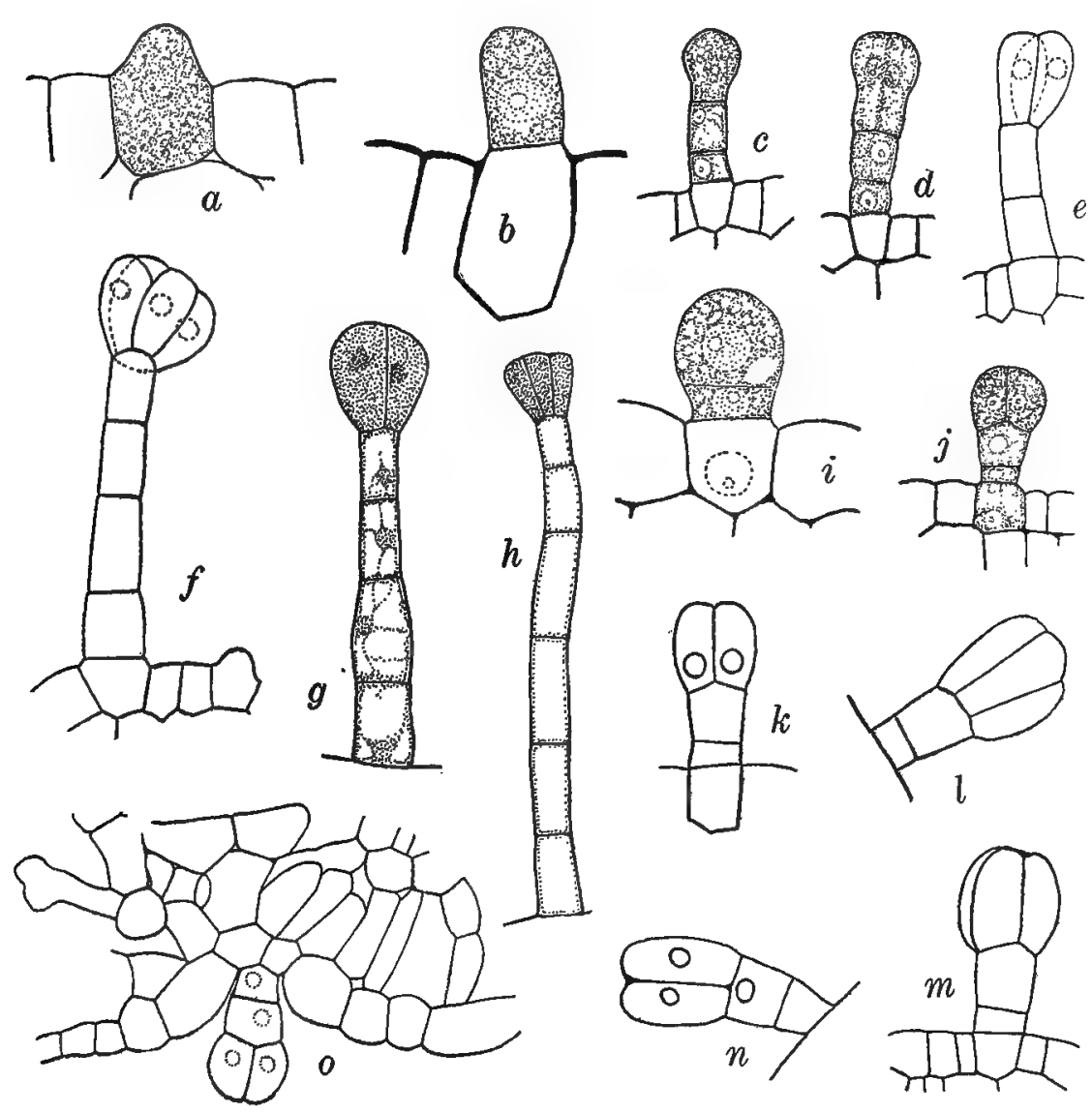

Fig. 5-Trichomes of Juglans californica: $a$ to $h$, various stages in the development of long secreting trichomes $(a, c, d, f$, and $q \times 535 ; b \times 1200) ; i$ to o, mature and young short secreting trichomes $(\times 535)$.

In studying this type of trichome it was found best to measure the head only, since the entire trichome, which is relatively long, varies considerably. Wherever possible the position of the trichome on the leaf is given, but whenever this is not done it is to be understood that in every instance 
trichomes from analogous situations only are compared, so that the results in such cases may be considered just. Following are measurements, in $\mu$, on the length and diameter of the heads of the long secreting trichomes which were taken from the veins of the leaves: length, 29.4, 31.5, 35.7, $33.6,33.5,31.5,29.4,25.2,29.4,29.4,33.6,25.2$; diameter, 25.2, 23.1, $29.4,25.2,25.2,27.3,29.4,31.5,25.2,25.2,29.4,27.3$. The diameters of the heads are the diameters seriatim of those whose lengths are given previously. The heads average $30.6 \mu$ in length and $26.8 \mu$ in diameter. In length the variation from the average is 13 per cent, and the variation from the average diameter is 15 per cent.

The material of Juglans californica which was put up was not favorable for the study of the youngest stages in the development of the short secreting trichomes, so that a description of the mature organ only is possible in this place. The trichome is made up of 6 cells, of which 2 constitute the stalk and 4 the head (fig. 5, $i$ to 0 ), which are so placed as to form a disk 1 cell in thickness.

A character which easily distinguishes the short secreting trichomes of Juglans californica from those of Juglans regia or Juglans nigra is the length of the head-cells. As the figures indicate, the cells of the head of the short secreting trichome in Juglans californica are relatively long, which is a consistent character of the long secreting trichome as well, and it is this circumstance which makes advisable the comparison of the lengths of the heads in both pure species and hybrids, although other measurements have also been made. The measurements on the length and the diameter of the heads, as well as the lengths of the entire short secreting trichomes, together with notes on the positions occupied by the trichomes, are presented herewith.

The lengths of the heads of the short secreting trichomes are greater for trichomes which are on the veins than for those which occur between them. The measurements, in $\mu$, are: length of heads, on veins, $35.7,33.6,27.3$, $29.4,27.3,27.4,27.3,33.6,33.6,33.6,33.6,29.4$; diameters of the same heads, respectively, 25.2, 23.1, 29.4, 25.2, 27.3, 29.4, 23.1, 31.5, 25.2, 25.2, $29.4,27.3$; length of heads, between veins, 27.3, 21.0, 25.2, 29.4, 25.2, 29.4; diameters of the same heads, 25.2, 25.2, 25.2, 25.2, 25.2, 29.4. The heads from trichomes on the veins average $30.9 \mu$, in length and $26.8 \mu$ in diameter. The average lengths of heads from between the veins is $26.2 \mu$ and they average $25.9 \mu$ in diameter. The heads of trichomes on the veins show a variation in length of 13 per cent from the average; those between the veins, a departure of 16 per cent from the average. The variation from the average in diameter for the two series is respectively 13 and 8 per cent.

Although it is recognized that the small number of measurements lessens the valie of the results in any instance, as a whole the number of measure- 
ments made upon analogous organs is considerable, so that for a comparative study they may not be without value. It is therefore of interest to note that the departure in per cent from the average of trichomes on the veins is the same in the long secreting trichome as in the one just considered.

Table 7 gives the 1ength of the trichomes, the length and diameters of the heads, and gives the area from which the trichomes were taken.

TABLE 7.-Measurements on short secreting trichomes of Juglans californica.

VENTRAL SURFACE.

\begin{tabular}{|r|r|r|}
\hline $\begin{array}{r}\text { Length of } \\
\text { trichome. }\end{array}$ & $\begin{array}{c}\text { Length } \\
\text { of head. }\end{array}$ & $\begin{array}{c}\text { Diameter } \\
\text { of head. }\end{array}$ \\
\cline { 1 - 3 }$\mu$ & $\mu$ & $\mu$ \\
37.7 & 18.9 & $(?)$ \\
37.8 & 21.0 & 25.2 \\
37.8 & 25.2 & 25.2 \\
39.9 & 21.0 & 27.3 \\
37.8 & 18.9 & 23.1 \\
46.2 & 25.2 & 25.2 \\
42.0 & 23.1 & 29.4 \\
39.4 & 16.8 & 21.0 \\
33.6 & 18.9 & 21.0 \\
& & \\
\hline \multicolumn{2}{|c|}{ DORSAL SURFACE. } \\
\hline$\mu$ & \multicolumn{2}{|c|}{} \\
44.1 & 23.1 & 25.2 \\
54.6 & 27.3 & 29.4 \\
42.0 & 25.2 & 25.2 \\
46.2 & 25.2 & 27.3 \\
\hline
\end{tabular}

The average length of the entire trichome from the ventral surface is $39.2 \mu$, from the dorsal surface is $46.7 \mu$. The average length of the heads of trichomes from the ventral surface is $21.0 \mu$, the average diameter is $24.6 \mu$. The averages for the length and the diameter of heads of trichomes taken from the dorsal surface are $25.2 \mu$ and $26.7 \mu$, respectively.

The measurements given in table 7 are of trichomes from old leaves; those given just previously were from young leaves; we therefore have an additional condition of the trichomes for comparison, $i . e_{\text {. }}$, a comparison of those from the young and from the old leaf. In the instance of the young leaves the average length of the heads of trichomes which were on the veins was found to be greater than the average of those which occur between them. In the old leaves the heads of trichomes were larger on the dorsal surface than on the ventral, although the number was so small that their relation on and between the veins could not well be worked out. A comparison of the average length of heads from the ventral surface of the old leaf and of the young brings out the fact that the heads are longer 
in the young than in the old leaf, which condition must be taken into consideration in such a comparative study as the present one.

\section{JUGLANS NIGRA.}

The following kinds of trichomes are to be found on the leaves of Juglans nigra: (1) awn-shaped, (2) disk-shaped, (3) short secreting trichomes, and (4) two types of the long secreting trichomes (figs. 6 and 7).

The awn-shaped trichomes measure $252 \mu$ more or less in length and are unicellular. They occur either singly or in groups of 3 or more. The awnshaped trichome is especially abundant on the young leaves, where it is found on the ventral surface only, although it persists to a degree, so that scattering trichomes are met on the older leaves as well.

The disk-shaped trichomes are relatively short and have broadly expanded heads which are closely appressed to the surface. In longitudinal section a disk-shaped trichome is seen to consist of a saucer-shaped head and a stalk of 2 cells, although an occasional trichome is found which has a stalk of 3 cells (fig. $6, k$ ). Certain stages in the development of the disk-shaped trichomes were observed. It was seen to arise from the epidermis as a squat projection which is soon separated from it by a transverse wall. A second transverse division follows, by which the head is differentiated from the stalk. The terminal cell next undergoes division by longitudinal walls, so that a 4-celled condition results. The stalk-cell, by the formation of a transverse wall, attains the adult number of cells, 2, when cell-division of the stalk ceases.

In two cases the failure to form a second transverse wall in the stalk was noted. The cells of the head divide by the formation of longitudinally placed walls only and are finally composed of 24 or more cells. The head, therefore, is an expanded plate of cells 1 cell in thickness. The heads were $75 \mu$ more or less in diameter and the depression of the head was $25 \mu$ more or less beneath the rim.

Table 8 gives in detail the diameter of the heads and the depth of the depression in several representative and mature disk-shaped trichomes.

TABLE 8.-Measurements of disk-shaped trichomes of Juglans nigra.

\begin{tabular}{|c|c||c|c|c|c|}
\hline $\begin{array}{c}\text { Diameter } \\
\text { of } \\
\text { trichome. }\end{array}$ & $\begin{array}{c}\text { Depth of } \\
\text { depression } \\
\text { of head. }\end{array}$ & $\begin{array}{c}\text { Diameter } \\
\text { of } \\
\text { trichome. }\end{array}$ & $\begin{array}{c}\text { Depth of } \\
\text { depression } \\
\text { of head. }\end{array}$ & $\begin{array}{c}\text { Diameter } \\
\text { of } \\
\text { trichome. }\end{array}$ & $\begin{array}{c}\text { Depth of } \\
\text { depression } \\
\text { of head. }\end{array}$ \\
\hline$\mu$ & $\mu$ & $\mu$ & $\mu$ & $\mu$ & $\mu$ \\
75.6 & 29.4 & 71.4 & 25.2 & 92.2 & 21.0 \\
92.6 & 29.4 & 84.0 & 25.2 & 67.2 & 25.2 \\
69.3 & 25.2 & 71.4 & 18.9 & 79.8 & 25.2 \\
711.4 & 29.4 & 63.0 & 21.0 & 84.0 & 25.2 \\
79.8 & 25.2 & 84.0 & 25.2 & & \\
\hline
\end{tabular}


In table 8 the figures in the right-hand columns are the depths of the depressions of the trichomes whose diameters are given in the corresponding lines in the left-hand columns.

The average diameter of the heads of the disk-shaped trichomes is $77.5 \mu$; the average depth of the depression of the heads is $25.0 \mu$. Reference to the measurements on the disk-shaped trichomes in Juglans californica, given



FIG. 6.-Trichomes of Juglans nigra: $a$, aw $\mathrm{b}$-shaped trichome (ca., $242 \mu) ; b$ to $k$, development of disk-shaped trichomes $(b, e, d$, e, $f, i$, and $k, x, 535 ; g, h$, and $j, \times 84) ; l$ to $q$, stages in development of long secreting trichomes $(\times 535 ; l \times 1200)$. (Reduced one-fifth).

at page 21, will show that those of Juglans nigra are noticeably smaller, but the structure and the development, so far as known, of the two species is the same.

The long secreting trichomes are of two types, of which one has a head of 4 cells, and the other a head of about 8 cells. Of these the former will be described first. The trichome is $100 \mu$ to $150 \mu$ in length (fig. 7, $a$ to $e$ ). 
It takes its origin as a slender papillate projection of the epidermis, which is early cut off by a transverse wall, and which may occasionally be laid down somewhat above the general level of the epidermis. From a comparison with this type of trichome in other species it is probable that after the young trichome is separated from the epidermis it undergoes one additional transverse division when the distal cell enlarges and becomes the head and the proximal cell the stalk. Longitudinal walls are laid down in the terminal cell in such fashion as to cause the organization of 4 similar and radially placed cells. With this the cell formation in the region of the head is completed.

The stalk forms two other transverse walls (but it was not surely determined whether the fourth stalk-cell was formed during or after the divisions in the head as given above) when the cell-divisions in the region of the stalk are completed. The trichome thus is composed of 8 cells, 4 of which constitute the head and 4 the stalk. This relation was fairly constant, and may have held in all cases, since when the number of stalk-cells was more than 4 the head was relatively large and may always have had more than 4 cells.

Table 9 gives the measurements on long secreting trichomes of the type just described.

TABLE 9.-Measurements on long secreting trichomes of Juglans nigra.

\begin{tabular}{|c|c|c|c|c|c|}
\hline $\begin{array}{l}\text { Length } \\
\text { of head. }\end{array}$ & $\begin{array}{l}\text { Diameter } \\
\text { of head. }\end{array}$ & $\begin{array}{l}\text { Length } \\
\text { of head. }\end{array}$ & $\begin{array}{l}\text { Diameter } \\
\text { of head. }\end{array}$ & $\begin{array}{l}\text { Length } \\
\text { of head. }\end{array}$ & $\begin{array}{l}\text { Diameter } \\
\text { of head. }\end{array}$ \\
\hline$\mu$ & $\mu$ & $\mu$ & $\mu$ & $\mu$ & $\mu$ \\
\hline 21.0 & 33.6 & 16.8 & 33.6 & I6.8 & 35.7 \\
\hline I6.8 & 37.8 & I 6.8 & 37.8 & 16.8 & $33 \cdot 6$ \\
\hline I6. 8 & 35.8 & 16.8 & 39.8 & 16.8 & 42.0 \\
\hline 16.8 & 42.0 & 21.0 & 42.0 & 16.8 & 33.6 \\
\hline г6.8 & 37.8 & 18.9 & 39.9 & I 6.8 & $3 \mathrm{I} \cdot 5$ \\
\hline
\end{tabular}

The heads of the trichomes average $17.6 \mu$ in length and $37.4 \mu$ in diameter. The variation from the average length is 12.5 per cent, and the variation from the average diameter is 14 per cent. From these measurements it is seen that the heads of the long trichomes of the 4-celled type are considerably shorter than the analogous ones in Juglans californica and that the relation of length to diameter of the head in the two species is also unlike; the diameter is the greater in Juglans nigra and the length is the greater in Juglans californica. But the variation from the average length is identical in the two species, and the variation from the average diameter is nearly the same.

The long secreting trichome of the second type, that with more than 4 cells constituting the head, is fairly abundant in Juglans nigra. This type of trichome has a stalk fof from 5 to 9 cells and a head of about 8 cells Only a few stages in the development of the trichome were seen, but these 
were sufficient to indicate that this is essentially different from the long secreting trichome of the other type. Fig. $7, g$, shows a cross-section of a head which has reached the 5-celled stage. The fifth cell is formed by the laying down of a radially placed wall by which the mother-cell is divided unequally. In fig. $7, f$, each of the 4 cells is divided by a radial wall, so that the mature, or 8-celled, condition has resulted.

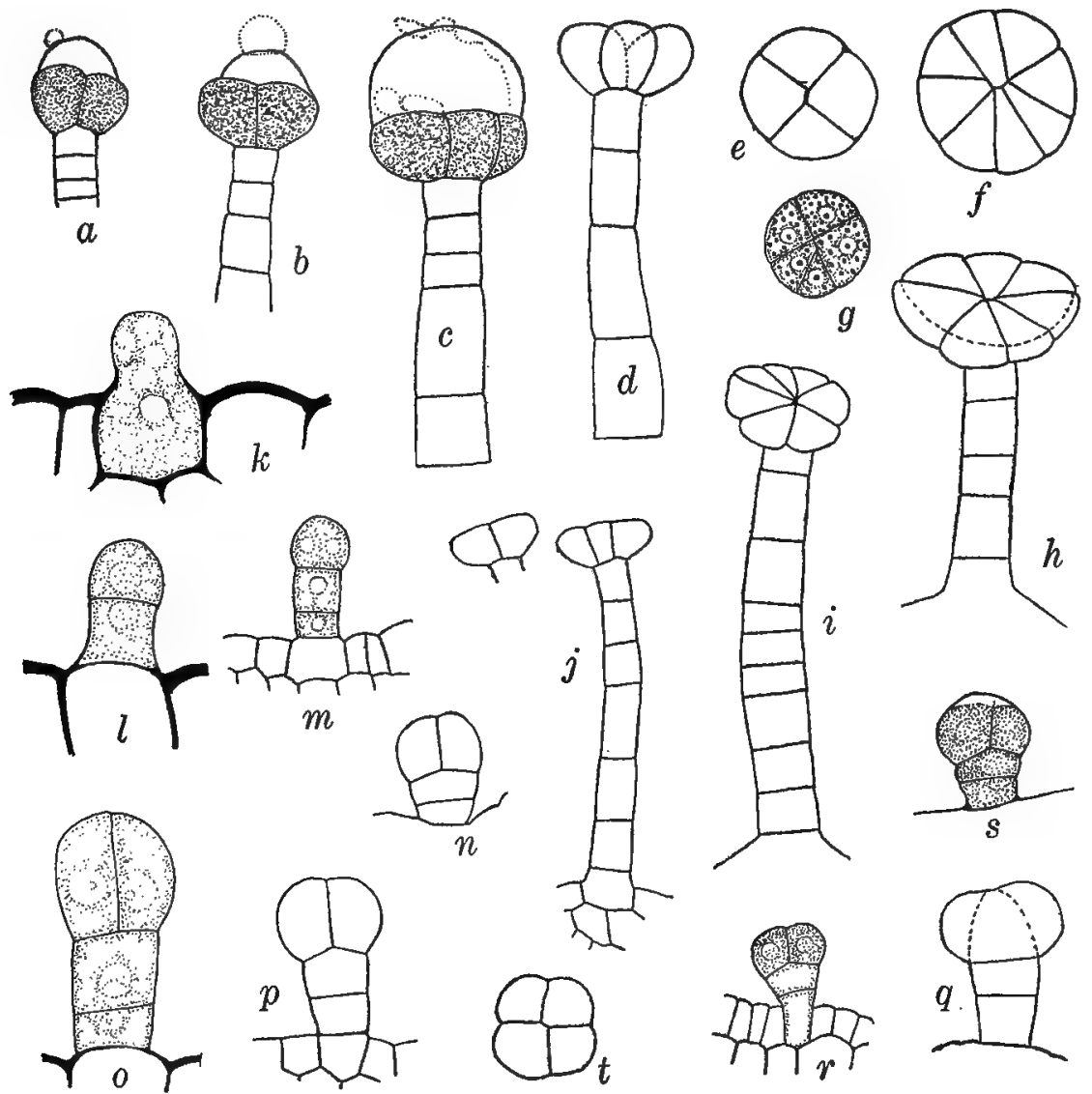

FrG. 7.-Trichomes of Juglans nigra: $a$ to $e$, long secreting trichomes $(a, b, c, d$, and $e \times 535)$; $f$ to $j$, long secreting trichomes of the type having a head of more than 4 cells ( $f, g$, and $h$, $\times 535 ; i$ and $j \times 84$ ); $k$ to $t$, short secreting trichomes, of which $n$ to $r$ are from the reglon of the veins of the leaves and $s$ is from the leat-margin $(k, l$, and $u, \times 1200 ; m, r, p, q, r, s$, and $t$, $\times 535$ ). (Reduced one-fifth).

In several trichomes the head was observed to be composed of 7 cells only, but whether these were immature or not was not determined. From a careful study of this type of trichome it would seem that 8 is the usual number of cells in the head. No measurements were made on the length of the heads, but the following numbers, in $\mu$, give the diameter for the type of trichome in question. The measurements were made only on what were thought to be mature forms. Diameter of heads: $54.6,50.4$, 
$48.3,50.4,50.4,56.6,46.2,52.6$. That this is a type of trichome distinct from the 4-celled one is apparent from the diameters of the head. The smallest head of the 8-celled type is considerably larger than the largest of the 4-celled form, while the largest is more than 25 per cent larger than these.

No study was made of the excretions or especially of the structure of the secreting cells; the 8-celled type was the only one which gave indication of marked activity in this regard. In such trichomes as shown in fig. 7, $c$, it appears as if the secretion is held for a time between the layers of the cell-walls which are on the distal end of the trichome. The appearance figured was not observed in other trichomes.

The short secreting trichomes occur on both surfaces of the leaf; they measure from $27.3 \mu$ to $50.4 \mu$ in length. Whatever may be the size of the trichome the terminal group of cells is relatively short, so that the head has a squat appearance.

The early stages in the development of the short secreting trichome are apparently similar to those of the same type of trichome in Juglans californica. As usual for the trichomes, the origin is to be traced to rather narrow outgrowths of epidermal cells. The young trichome undergoes two successive transverse divisions, by which it is separated from the epidermis and by which the initial of the head is differentiated from that of the stalk. The following division is probably longitudinal in the head-cell, followed by a division of the stalk, by which the divisions in the stalk are concluded, and this is followed by the second and third longitudinal divisions of the head, which take place in such manner that 4 radially placed cells result. With the organization of a head of 4 cells and a stalk of 2 cells the cell-division in the trichome ceases.

TABLE 10.-Measurements on short secreting trichomes from young leaves, Juglans nigra.

\begin{tabular}{|c|c|c|c|c|c|}
\hline \multicolumn{4}{|c|}{ On the veins. } & \multicolumn{2}{|c|}{ Between the veins. } \\
\hline \multicolumn{2}{|c|}{ Length of head. } & \multicolumn{2}{|c|}{ Diameter of head. } & \multirow{2}{*}{$\begin{array}{l}\text { Length } \\
\text { of } \\
\text { head. }\end{array}$} & \multirow{2}{*}{$\begin{array}{c}\text { Diameter } \\
\text { of } \\
\text { head. }\end{array}$} \\
\hline $\mathbf{I}$. & 2. & I. & 2. & & \\
\hline$\mu$ & $\mu$ & $\mu$ & $\mu$ & $\mu$ & \\
\hline 21.0 & 21.0 & 35.7 & 31.6 & 14.7 & Not given \\
\hline 21.0 & 18.9 & 33.6 & 33.6 & 16.8 & \\
\hline $23 \cdot 3$ & 18.9 & 33.6 & 29.4 & 16.8 & \\
\hline 16.8 & $\ldots . .$. & 29.4 & $\ldots . .$. & 14.7 & \\
\hline 16.8 & $\ldots \ldots$ & 33.6 & $\ldots \ldots$ & 14.7 & \\
\hline 21.0 & $\ldots \ldots$ & $35 \cdot 7$ & $\ldots .$. & 16.8 & \\
\hline 16.8 & $\ldots \ldots$ & $3 I \cdot 4$ & ....... & 16.8 & \\
\hline 29.4 & $\ldots \ldots$ & 16.8 & $\ldots \ldots$ & 16.8 & \\
\hline 25.2 & $\ldots \ldots$ & 29.4 & $\ldots \ldots$ & 16.8 & \\
\hline 21.0 & $\ldots \ldots$ & 33.6 & $\ldots \ldots$ & & \\
\hline 21.0 & $\ldots \ldots$ & $35 \cdot 7$ & $\ldots \ldots$ & & \\
\hline 16.8 & ....... & $29 \cdot 4$ & ....... & & \\
\hline 21.0 & $\ldots \ldots$ & 31.6 & $\ldots \ldots$ & & \\
\hline
\end{tabular}


On the veins the average length of the heads is $20.8 \mu$; the average diameter is $31.5 \mu$. Between the veins the average length of the heads is $16.2 \mu$; the diameters are not given. The variation from the average length of the heads of trichomes from the region of the veins is 31.5 per cent; the variation in diameter is 60 per cent. The variation in length of heads from trichomes which were from between the veins is 0.9 per cent.

TABLE 11.-Measurements of short secreting trichomes from old leaves, Juglans nigra.

\begin{tabular}{|c|c|c|c|c|c|}
\hline \multicolumn{3}{|c|}{ Dorsal surface. } & \multicolumn{3}{|c|}{ Ventral surface. } \\
\hline $\begin{array}{l}\text { Length of } \\
\text { trichome. }\end{array}$ & $\begin{array}{l}\text { Length of } \\
\text { head. }\end{array}$ & $\begin{array}{l}\text { Diameter } \\
\text { of head. }\end{array}$ & $\begin{array}{l}\text { Length of } \\
\text { trichome. }\end{array}$ & $\begin{array}{c}\text { Length of } \\
\text { head. }\end{array}$ & $\begin{array}{l}\text { Diameter } \\
\text { of head. }\end{array}$ \\
\hline $\begin{array}{r}\mu \\
27.3 \\
27.3 \\
* 50.4 \\
37.8 \\
33.6 \\
33.6\end{array}$ & $\begin{array}{l}\mu \\
14.7 \\
12.6 \\
23.0 \\
21.0 \\
16.8 \\
12.6\end{array}$ & $\begin{array}{c}\mu \\
25.2 \\
25.2 \\
31.5 \\
33.6 \\
27.3 \\
21.0\end{array}$ & $\begin{array}{c}\mu \\
27.3 \\
23.1 \\
25.2 \\
25.2 \\
25.2 \\
* 31.5 \\
25.2 \\
27 \cdot 3 \\
25.2\end{array}$ & $\begin{array}{c}\mu \\
\text { I4.7 } \\
\text { I } 2.6 \\
\text { I } 2.6 \\
\text { I } 2.6 \\
\text { I } 2.6 \\
\text { स }_{2} \text { I.0 } \\
\text { I } 2.6 \\
\text { I } 2.6 \\
\text { I } 1.5\end{array}$ & $\begin{array}{c}\mu \\
27.3 \\
21.0 \\
25.2 \\
25.2 \\
21.0 \\
{ }^{2} 33.6 \\
21.0 \\
12.6 \\
18.9\end{array}$ \\
\hline
\end{tabular}

The average length of heads from the dorsal surface is $16.8 \mu$; the average length of heads of trichomes from the ventral surface, including the abnormally large one, is $13.4 \mu$; omitting that one, the length is $12.5 \mu$. The average length of the trichomes on the dorsal surface is $35.0 \mu$; the average length on the ventral surface is $26.1 \mu$. The variation in length of the heads from the dorsal surface is 20 per cent; from the ventral surface 62 per cent.

From the study of the short secreting trichome it appears, therefore, that trichomes from the regions of the veins in the young leaves have longer heads than those from the areas between them, and that the length of the heads of trichomes from the dorsal surface of old leaves is greater than from the ventral surface. The entire trichomes also are longer on the dorsal surface; and the heads of trichomes of young leaves are greater than the length in old leaves.

\section{JUGLANS REGIA.}

The types of trichomes which were seen in the two species of Juglans as above described were observed in Juglans regia also. These are, (1) the awn-shaped trichome; (2) the disk-shaped trichome; (3) one or perhaps two types of long secreting trichomes, and (4) the short secreting trichomes (fig. 8). 
The awn-shaped trichomes occur on the ventral surface of the leaves only and are especially abundant on young leaves. They sometimes are found in groups, especially in young leaves, but in older ones they usually occur singly; they measure $126 \mu$, more or less, in length.

As distingnished from the awn-shaped trichome, which is unicellular and non-secreting, the other forms are glandular and are multicellular. The mature disk-shaped trichome consists of a 2-celled stalk and a flattened head, 1 cell in thickness, of about 32 cells. The youngest stages in development were not seen. After the head has been differentiated and divided into 4 similar cells, each quadrant becomes divided unequally by radial walls, so that a head of 8 cells results (fig. $8, c$ ). Later each octant is divided by walls which extend outwards from the newly-formed octant walls and a head of 16 cells is the result. The actual formation of walls subsequently was not observed. Usually the cell-division in the head proceeds in a regular manner, so that the product is symmetrical, but a single monstrous trichome was seen in which this had not been the case. The history of this trichome, naturally, could not be studied; it is shown at $i$, fig. 8 .

Measurements on the disk-shaped trichomes show that they vary both in diameter and in depth in a regular manner, which is to be related to the relative age of the leaf where found. Following are given measurements, in $\mu$, on the diameter and the depth of disk-shaped trichomes on young leaves: diameter, $105.0,109.2,105.0$; depth, 8.4, 8.4, 12.6, 16.8, respectively. The trichomes are not so abundant on old leaves and, as the following figures $(\mu)$ show, they are also of less diameter; the depth is not given: diameter, $58.8,50.4,46.2,46.2,58.8,46.6,42.0,42.0,50.4,58.8$, averaging 45.0 .

The long secreting trichome measures $96 \mu$, more or less, in length. The mature trichome consists of a head of 4 cells and a stalk of 4 cells (fig. $8, j$ to $m$ ). It takes its origin as a papillate projection of an epidermal cell which is early cut off from the epidermis by a wall parallel to it. The young trichome next undergoes transverse division, by which the portion which is to become the head is differentiated from the portion which is to be the stalk. The second division and the third division were not seen, but are probably longitudinal in the head rudiment and transverse in the stalk rudiments, respectively, as in the long secreting trichomes of the pure species; as well as hybrids, where the sequence has been carefully followed.

Either following the divisions by which the head becomes 4-celled, or pari passu with these, the two final divisions of the stalk take place. Of these divisions that of the outer cell occurs first. When the trichome is mature the head is relatively long, but the material at hand was not favorable for a comparative study of the long secreting trichome, so that a more precise statement can not at present be made. It was almost entirely absent from old leaves and not very abundant on the young ones. The 




Fit. 8-Trichomes of Juglans regia: $a$, awn-shaped trichomes (X 84): $b$ to $h$, stages in the development of disk-shaped tricbomesi $(\times 535)$; $i$, abnormal disk-shaped trichome $(\times 1200)$; $j$ to $m$, long secreting trichomes $(j$ and $k \times 1200 ; l$ and $m \times 535): n$ to $r$, development of short secreting trichomes, of which $r$ is a transverse view of $q(n, 0$, and $p \times 1200 ; q$ and $v \times 535)$; s to $v$, short secreting trichomes from rather old leaf ( $\times 535$ ); $w$, short secreting trlchomes from growing tip of stem $(\times 585$ ). (All figures reduced one-fourth.) 
second form of long secreting trichome, which was found in Juglans nigra especially, was not surely determined for this species; if, indeed, it occurs in Juglans regia at all it is rare.

The short secreting trichome is to be found on both surfaces of the leaves, both old and young, although it is more abundant on the latter. Only two of the young stages in development of the short trichome were observed. After separation from the epidermis the next succeeding celldivision cuts of the head-cell from the stalk-cell. When mature the trichome consists of 2 stalk-cells and 4 head-cells (shown in fig. $8, n$ to $w$ ).

The short secreting trichome shows a considerable variation in size which appears to be directly associated with the position occupied by it. The variation is especially noticeable in the length of the head. Table 12 illustrates the range of variation in length of head in young and old leaves and in stem.

\section{TABLE 12.-Measurements of short secreting trichomes, Juglans regia.- Length of head.}

\begin{tabular}{|c|c|c|}
\hline $\begin{array}{c}\text { Young } \\
\text { leaf. }\end{array}$ & $\begin{array}{c}\text { Young } \\
\text { stem. }\end{array}$ & \multicolumn{1}{|c|}{$\begin{array}{l}\text { Old } \\
\text { leaf. }\end{array}$} \\
\cline { 2 - 3 }$\mu$ & $\mu$ & $\mu$ \\
29.4 & 21.0 & 16.8 \\
27.4 & 21.0 & 8.4 \\
29.4 & 29.4 & 16.8 \\
29.4 & 29.4 & 16.8 \\
29.4 & & 12.6 \\
25.2 & & \\
25.2 & & \\
\hline
\end{tabular}

The average length of the trichomes from the dorsal surface is $29.2 \mu$, from the ventral surface, $25.2 \mu$. The length of the heads of dorsally placed trichomes is also slightly longer than those of the ventrally placed ones; those of the former average $14.3 \mu$ and those of the latter is $13.6 \mu$ (table 13).

TABIE 1:3. -Measurements on short secreting trichomes, Juglans regia.

\begin{tabular}{|c|c|c|c|c|c|}
\hline \multicolumn{3}{|c|}{ Dorsal surface. } & \multicolumn{3}{|c|}{ Ventral surface. } \\
\hline $\begin{array}{l}\text { Length of } \\
\text { trichome. }\end{array}$ & $\begin{array}{l}\text { Length of } \\
\text { head. }\end{array}$ & $\begin{array}{l}\text { Diameter } \\
\text { of head. }\end{array}$ & $\begin{array}{l}\text { Length of } \\
\text { trichome. }\end{array}$ & $\begin{array}{l}\text { Length of } \\
\text { head. }\end{array}$ & $\begin{array}{l}\text { Diameter } \\
\text { of head. }\end{array}$ \\
\hline$\mu$ & $\mu$ & $\mu$ & $\mu$ & $\mu$ & $\mu$ \\
\hline 28.4 & 16.8 & $27 \cdot 3$ & 284 & 14.7 & 21.0 \\
\hline $23 \cdot I$ & 14.7 & 25.2 & 25.2 & 12.6 & 21.0 \\
\hline 33.6 & 14.7 & 23.1 & 25.2 & I2 6 & 21.0 \\
\hline 29.4 & โ2.6 & 23.0 & 25.2 & I2.6 & 25.2 \\
\hline $3 \pi \cdot 5$ & 14.7 & 25.2 & 23.1 & 14.7 & 25.2 \\
\hline 29.4 & J2.6 & 23.1 & 25.2 & 14.7 & 21.0 \\
\hline
\end{tabular}




\section{GENERAL COMPARISON OF THE LEAVES AND THE TRICHOMES IN PURE SPECIES OF JUGLANS.}

In leaf-characters the pure species of Juglans are fairly sharply separated from one another. For example, in number of leaflets regia has less than one-half those of either of the other species, and the range in number of leaflets in californica is considerably less than the range in nigra. In form of the leaflets the species are not so sharply distinguishable. The leafcharacter, however, is a good one to observe in the hybrids between these species.

Although somewhat difficult in all cases to speak with certainty, with a single exception it appears that all of the types of trichomes occurring in any one species may be found in all, and, further, that the leading points in structure and development are the same wherever the trichome is to be found. Four types of trichomes occur in californica and regia and an additional type in nigra. Of these, one form is unicellular and lifeless, the others are multicellular and glandular. So far as could be determined from the material at hand, each type of multicellular trichome appears to have its peculiar manner of development, as suggested above, to which it adheres with great consistency. After the trichome rudiment has been formed the divisions of the short secreting trichome were, first, a crosswall separating the head from the stalk; second, a longitudinal wall in the head; third, a cross-wall in the stalk; and fourth and fifth, two longitudinal divisions of the head. The long secreting trichome experiences the same sequence of cell-divisions and to them adds 2 in the stalk. The sequence of division of the disk-shaped trichome is the same for the first two divisions, after which it divides in another manner, which is thought to be, although not actually proved to be, also consistent. As a result of the divisions the heads of the various trichomes become 4, 8, and probably 32 celled.

Although abnormalities were observed they were not always intermediate between any of the types, and in fact no intermediates were noticed.

The multicellular trichomes varied in size to a considerable degree, but the variation was fairly consistent and was usually to be related to position on the leaf or to age of the leaf. The trichomes and the heads of trichomes also were each longer on the dorsal surface than on the ventral, on old than on young leaves, and on the veins than between them.' Nothing was observed on the changes in size of the trichome-heads accompanying their functional activity, if such occurs, and the variation is probably to be explained on other grounds.

The heads of the trichomes in the pure species Juglans californica are markedly longer than those of either of the other species; those of Juglans nigra are shortest. The differences in length lie from 50 to 75 per cent, so that this is a very good character to study in any cross in which Juglans californica is one of the parents. 


\title{
HYBRIDS OF JUGLANS.
}

\section{LEAVES OF THE HYBRIDS.}

\author{
JUGLANS CALIFORNICA $\times$ JUGLANS NIGRA.
}

The walnut hybrid of this parentage was formed by Mr. Burbank in 1878 and is known as the "Royal." One specimen of the first generation, which is the sole representative of this generation, is now growing at the Sebastopol ranch of Mr. Burbank. It is a very handsome tree, about 20 meters high, with a wide-spreading top. Some second and some third generation seedlings, the latter known as the "Beeson" walnut, are growing near the Royal at Sebastopol.

The Royal is distinguished by its rapid growth, by the fine grain of the wood, and by the relatively wide annual rings of growth. The second and third generation seedlings are extremely variable. This is noted in size, in vigor of the plants, and in the color, size, texture, and other characters of the leaves. The Royal fruits abundantly; the fruiting character of the later generations is not known.

The leaves are composed of from 5 to 9 or more pairs of leaflets, which may be strictly opposite on the rachis or may be more or less in alternation (plate 4). The terminal leaflet is usually smaller than the other leaflets, although it may also be larger than they are. It is generally single, but occasionally a doubling is to be seen. In form the leaflets vary from lanceolate, with a somewhat attentuate apex, to broadly ovate with an apex which is acuminate. The bases may be either abrupt or even cordate. The leaflets are serrate and exhibit all grades between fine and coarse serration. The surface of the leaves is either smooth or roughened, the veins of the dorsal surface may be either sunken or may be raised-generally the latter. As a whole, any type of leaflet, or quality appertaining to a leaflet, holds throughout all the other leaflets of the leaf.

So far as the general observations on the leaves of the three generations of the walnut hybrid go, the leaves show some grade of intermediacy. No leaf was seen which was not distinguishable from the leaves of either of the pure race, and all of the leaves examined showed characters of both. How far this remark will be good when each second or third generation plant is studied separately is not known.

\section{Juglans CALIFORNICA $\times$ Juglans REgia.}

This walnut hybrid, known as the "Paradox," originated from a cross made by Mr. Burbank in 1887. Four trees of the first generation are at present growing in the street in front of the experimental tract of Mr. Burbank in Santa Rosa. Seedlings of the second (and third) generation are at the Sebastopol ranch. The first-generation trees are about 28 meters high and about 25 meters spread. The bole of one of these trees, at a point 1.5 meters above the surface of the ground, measured $30 \mathrm{~cm}$. in 
diameter. Like the other walnut hybrid (the Roya1) this is a rapid grower; the wood is fine-grained, and the annual rings are relatively wide. The Paradox, unlike the Royal, however, bears little fruit.

The leaves of the first generation are extremely variable in number of leaflets, in size, and in many other particulars. Leaves with $3,4,5,6$, and 7 pairs of leaflets were selected for photographing (plate 7).

The number of pairs of leaflets are said by Mr. Burbank to reach as great a number as 19, though I did not see leaves with so great a number. Measurements on the extreme variation of the leaves were not made, but observation would indicate that the range may easily exceed 500 per cent.

The leaflets vary in outline from ovate to broadly ovate. The apices are acuminate or abrupt; sometimes they taper much as in the pure species Juglans californica. The bases are abrupt or even cordate; none are broadly cuneate, as in pure species referred to. The leaf-margins are remotely serrate. In all specimens examined the veins of the dorsal surface are prominent. The leaf-surfaces are usually smooth, although they may also be roughened. Thus each leaflet shows characters of both pure lines. Whether a similar condition will be seen to obtain in the later generations can not at present be stated.

The great tendency of the leaves of the Paradox hybrid to vary has been remarked by Mr. Burbank, who tells me that in company of two eminent scientists he selected 400 leaves or leaflets easily recognizable as different from one another.

TABLE 14.-Leaves of Juglans californica $\times$ Juglans nigra, $F_{1}$, compared with those of the pure species.

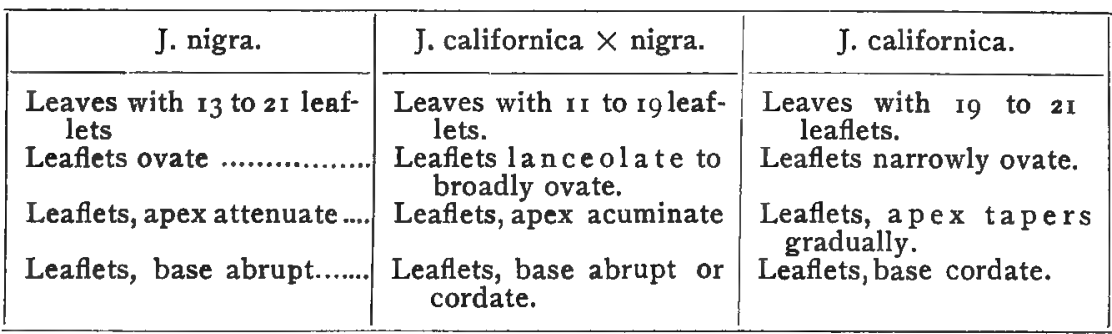

TABLE 15.-Lcaves of Juglans californica $\times$ Juglans regia, $F_{1}$, compared with those of the pure species.

\begin{tabular}{|c|c|c|}
\hline J. regia. & J. californica $\times$ regia. & J. californica. \\
\hline $\begin{array}{l}\text { Leaves with } 5 \text { to } 7 \text { leaf- } \\
\text { lets. } \\
\text { Leaflets broadly ovate...... }\end{array}$ & $\begin{array}{l}\text { Leaves with } 7 \text { to } 15 \text { leaf- } \\
\text { lets. } \\
\text { Leaflets ovate to broadly }\end{array}$ & $\begin{array}{l}\text { Leaves with I9 to } 2 \mathrm{I} \\
\text { leaflets. } \\
\text { Leaflets narrowly ovate. }\end{array}$ \\
\hline Leaflets, apex al & Leaflets, apex abrupt, or & Leaflets, apex tapers \\
\hline $\begin{array}{l}\text { Leaflets, base gradually } \\
\text { tapering. }\end{array}$ & $\begin{array}{l}\text { Leaflets, base abrupt, or } \\
\text { cordate. }\end{array}$ & Leaflets, base cordate. \\
\hline
\end{tabular}




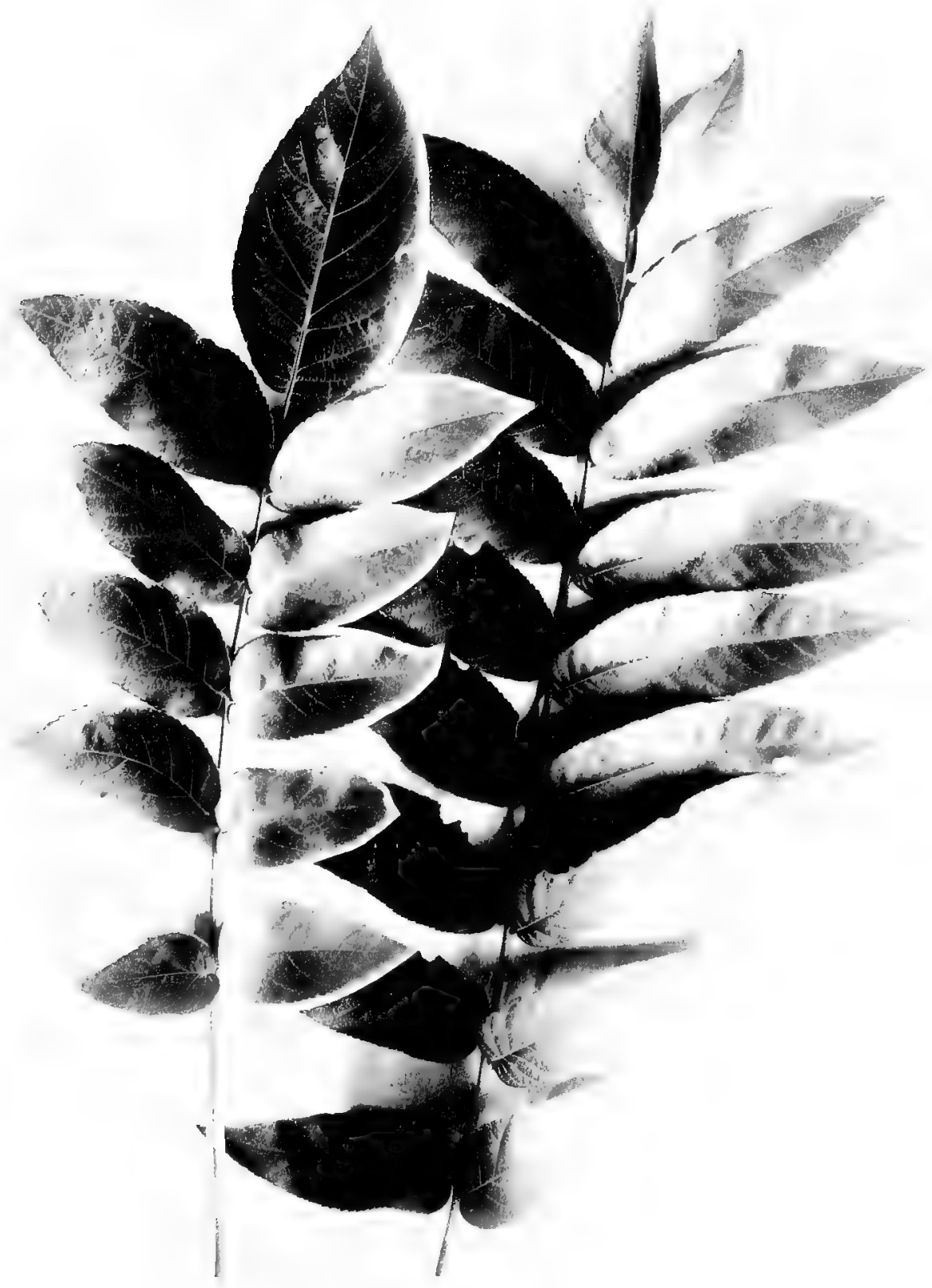

Leaves of Juglans californica $\times$ Juglans nigra, $F_{1}$, from Luther Burbank's Sebastopol ranch, to illustrate the range in variation. One-third natural size. 



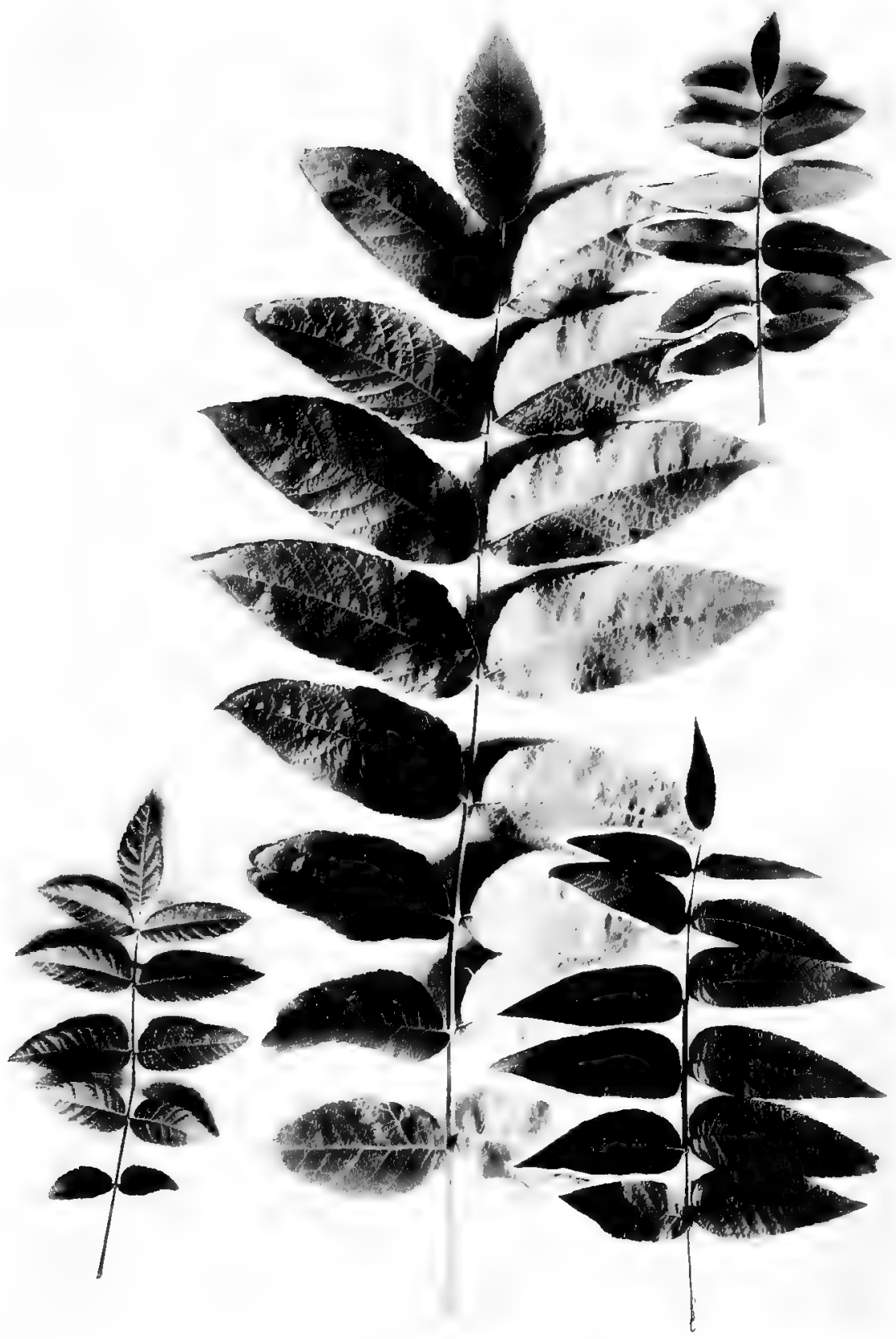

Leaves of Juglans californica $X$ Juglans nigra, $F_{2}$, to show extremes in variation of leaves and leaflets. From Luther Burbank's Sebastopol, California, ranch. The figures are reduced equally. One-third natural size. 
Trichomes of Juglans CALIFORNiCA $\times$ JUglans NigRa, $F_{1}$.

Four types of trichomes occur on the leaves of this hybrid. These are (1) the awn-shaped trichome, (2) the disk-shaped trichome, (3) the long secreting trichome (of two sorts), and (4) the short secreting trichome. The awn-shaped trichomes are unicellular and usually occur singly; they are found upon the ventral surface only of the leaves and measure $211 \mu$ more or less in length. While this type of trichome is especially abundant in young leaves, it persists to a degree, so that it may be found in mature leaves as well.

As in the pure species, the disk-shaped trichomes are composed of a short stalk and a broadly expanded head, of which the center is depressed (fig. 9). The supporting stalk is 2-celled; the head is of many, perhaps always of 32 cells, but is only 1 cell in thickness. The origin and development of the trichome were not shown satisfactorily in the material at hand, so that a description of these processes in hybrids of the first generation can not be given. Measurements, in $\mu$, on the diameter of the trichome and on the depth of the depression of the head were made as follows: diameter, $107.1,109.2,105.0,100.8,92.4,92.2$; depth, 8.4, 8.4, 18.9, $16.8,21.0,12.6$, respectively.

The longer secreting trichomes measure $126 \mu$ more or less in length and are of two types, which appear to be distinct. The more usual form consists of a stalk of 4 cells and a head of 4 cells which are radiate. The other form is composed of a stalk of a varying number of cells, usually more than 4, and a flat expanded head of about 8 cells. Although both forms occur on both surfaces of the same leaf, the latter is to be found chiefly, perhaps, on the veins. The more common form will be described first. After the young trichome has been cut off from the epidermis a transverse wall appears which separates the head portion from the part which will become the stalk. The next division of the trichome is also a transverse one and occurs in the stalk-cell. The third division takes place in the head-cell and is a longitudinal one. What the order of cell-divisions was after this was not learned. The heads of the mature trichomes are composed of rather long cells, so that in effect the head is neither like the head of the long secreting trichome in Juglans nigra, nor like that in Juglans californica, but holds an intermediate position. The following measurements, in $\mu$, were made on the heads of mature trichomes: length, $21.0,25.2,25.2,21.0,25.2,21.0,33.6,23.1,21.0,25.2,23.1,25.2$. The average of these is $24.1 \mu$.

The early stages in the development of the second type of long secreting trichome, that with a head of 8 cells, were for the most part not seen, but certain peculiarities in the cell-divisions of the head may be recorded. In transverse sections of the heads of all of the other trichomes studied the 

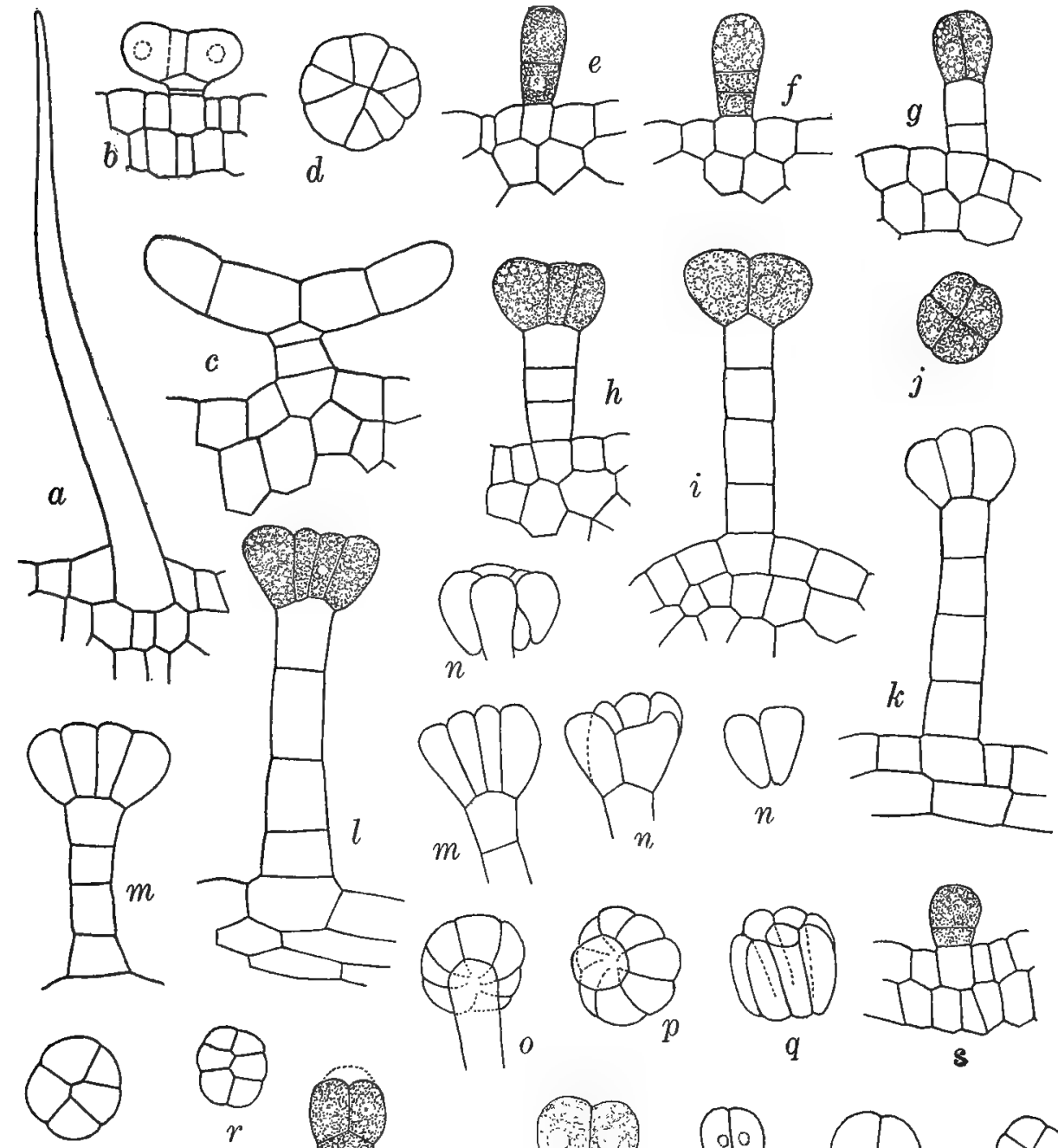

$m$
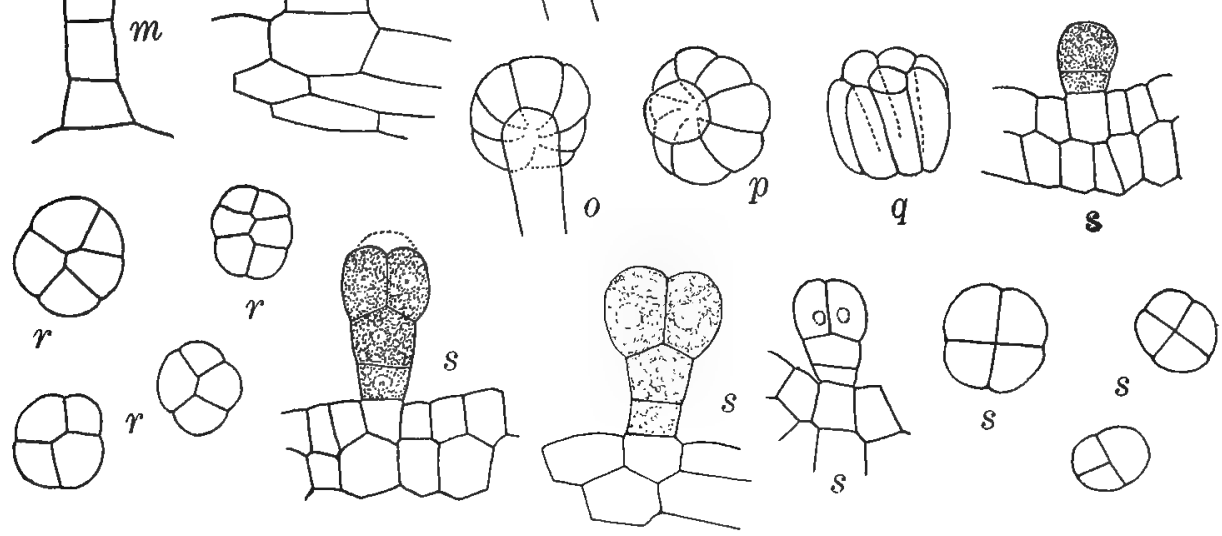

FrG.9.-Trichomes of Juglans californica $\Varangle$ nigr $\alpha, \mathbf{F}_{1}: a$, awn-shaped trichome from a leaf; $b$ to $d$, disk-shaped trichomes; $e$ to $i$, some stages in the development of long secreting trichomes; $j$, transverse section of head of mature long secretiug trichome; $k$ to $m$, long secreting trichomes; $n$ to $r$, long secreting trichomes of the type having a head of more than 4 cells; $n$, longitudinal sections of the head of a single trichome; $o$ to $q$, views of long secreting trichomes; $r$, transverse sections of head of long secreting trichomes of different ages; $s$, some stages in the development of short secreting trichomes. (All figures $\times 535$; reduced onefourth.) 
first three cell-walls are so arranged that a + -shaped figure results. In this type of the long secreting trichome, however, in which the 4,5 , and 6 cell stages of the head were seen, the arrangement of the walls is quite different and indicates that there may have been a very different sequence in the laying down of the walls from what ordinarily occurs. As nuclear division was not seen in the heads, however, what the sequence of celldivision was can not at present be told. In length of heads this type of long secreting trichome is not different from the type having a head of 4 cells. The following measurements, in $\mu$, were made: length, 21.0, 21.0, $25.2,29.2$. The diameter of such heads, however, is usually considerably greater.

The short secreting trichomes were found on both surfaces of all leaves but the oldest where they were apparently absent from the ventral side. In length they range from $35.7 \mu$ to $54.6 \mu$ and the size is evidently to be associated either with position on the leaf or with its age. The heads also of the trichomes in both pure species vary greatly in length, and here, also, the variation is probably in some manner connected with the position occupied on the leaf, or with the condition of the leaf, but when taken into consideration does not vitiate a comparison of similar organs which occur under analogous conditions. The material studied did not permit an observation of the development of this type of trichome, so that for the present a description of it must be omitted. The mature trichome consists of a 2-celled stalk and a head of 4 cells placed radially. The first division of the young trichome probably separates the stalk region from the head region, as in both the pure lines, and the divisions of the head are longitudinal. Measurements on the short secreting trichomes are given in table 16.

TARLE 16.-Measurements on the short secreting trichomes of Juglans californica $\times$ Juglans nigra, $F_{1}$.

\begin{tabular}{|c|c|c|c|c|}
\hline \multicolumn{2}{|c|}{$\begin{array}{c}\text { Trichomes from veins } \\
\text { of young leaves. }\end{array}$} & \multicolumn{3}{|c|}{$\begin{array}{l}\text { Trichomes from dorsal sur- } \\
\text { face of old leaves. } \dagger\end{array}$} \\
\hline $\begin{array}{l}\text { Length } \\
\text { of heads.* }\end{array}$ & $\begin{array}{l}\text { Diameter } \\
\text { of heads. }\end{array}$ & $\begin{array}{l}\text { Length of } \\
\text { trichomes. }\end{array}$ & $\begin{array}{l}\text { Length } \\
\text { of heads. }\end{array}$ & $\begin{array}{l}\text { Diameter } \\
\text { of heads. }\end{array}$ \\
\hline$\mu$ & $\mu$ & $\mu$ & $\mu$ & $\mu$ \\
\hline 21.0 & 21.0 & 37.8 & 16.8 & 25.2 \\
\hline 16.8 & 25.2 & $35 \cdot 7$ & 18.9 & 25.2 \\
\hline 21.0 & 25.2 & 39.9 & 18.9 & 23.1 \\
\hline 21.0 & 25.2 & 42.0 & 21.0 & 25.2 \\
\hline 18.9 & 25.2 & 42.0 & 23.1 & 25.2 \\
\hline 21.0 & $27 \cdot 3$ & $\$ 54.6$ & 25.2 & $29 \cdot 4$ \\
\hline 16.8 & 25.2 & & & \\
\hline 21.0 & 25.2 & & & \\
\hline \multirow[t]{2}{*}{21.0} & 25.2 & & & \\
\hline & & & & \\
\hline
\end{tabular}

* The average length of these heads is $19.8 \mu$; the average in diameter is $25.1 \mu$. †This type of trichome is absent from the ventral surface of old leaves. \pm Vein. 
The average length of the heads of trichomes of old leaves is $20.6 \mu$; the average diameter is $25.5 \mu$. Thus the lengths of heads in the old leaf and in the young leaf are practically the same. In the pure species, where the comparison is made, the young leaves were found to have the largest trichomes. It is possible that a comparison of trichomes from analogous leaf-surfaces would in this instance also give similar results.

Trichomes of Juglans californica $\times$ Juglans regia, $F_{1}$.

As in the pure species Juglans californica and Juglans regia, so also in the hybrid, 4 types of trichomes are to be distinguished, namely, the awnshaped, the disk-shaped, and the long and the short secreting trichomes. The unusual type of long secreting trichome which was observed in the other hybrid Juglans and in the pure species Juglans nigra appears not to be present in this hybrid (fig. 10).

\section{TABLE 17.-Measurements on heads of long secreting trichomes of Juglans californica $\times$ Juglans regia, $F_{1}$.}

\begin{tabular}{|c|c|c|c|}
\hline Length. & Diameter. & Length. & Diameter. \\
\hline$\mu$ & $\mu$ & $\mu$ & $\mu$ \\
21.0 & 37.8 & 25.2 & 37.8 \\
25.2 & 42.0 & 23.1 & 50.4 \\
21.0 & 46.2 & 23.1 & 39.9 \\
21.0 & 33.6 & 21.0 & 37.8 \\
\hline
\end{tabular}

The awn-shaped trichomes are most abundant in the young leaves, where they occur on the ventral surface only. They are of the usual type, unicellular, and range around $211.6 \mu$ in length.

The disk-shaped trichomes, which in structure are quite like those in both pure lines, consist of a flattened, multicellular head borne on a stalk of 2 cells. In young leaves the trichomes are to be found on both surfaces; in older ones they occur on the ventral surface only. Mature trichomes of this type vary greatly in diameter, but, so far as observed, the differences in diameter are more or less closely associated with differences in position on the leaves, and possibly also with the age of the leaf. The following measurements, in $\mu$, give the diameters of representative diskshaped trichomes: $71.4,73.6,67.2,65.0,75.6,92.2,79.8$. Of these the two last were from the region of the veins. The average diameter of the heads of the trichomes is $74.9 \mu$. A few measurements were made also to trace an additional possible character-the depth of the depression-for comparison with the pure lines. These measurements are as follows, in $\mu$ : diameter, 63.0, 84.0, 92.4, 79.8; depth, 12.6, 16.8, 12.6, 12.6, respectively.

The long secreting trichomes are most abundant on young leaves and are more abundant on the veins than between them. They occur on both leaf-surfaces. The trichome studied consists of a head with 4 radiate cells and a stalk of 4 cells. None of the type with a head of 8 cells was 


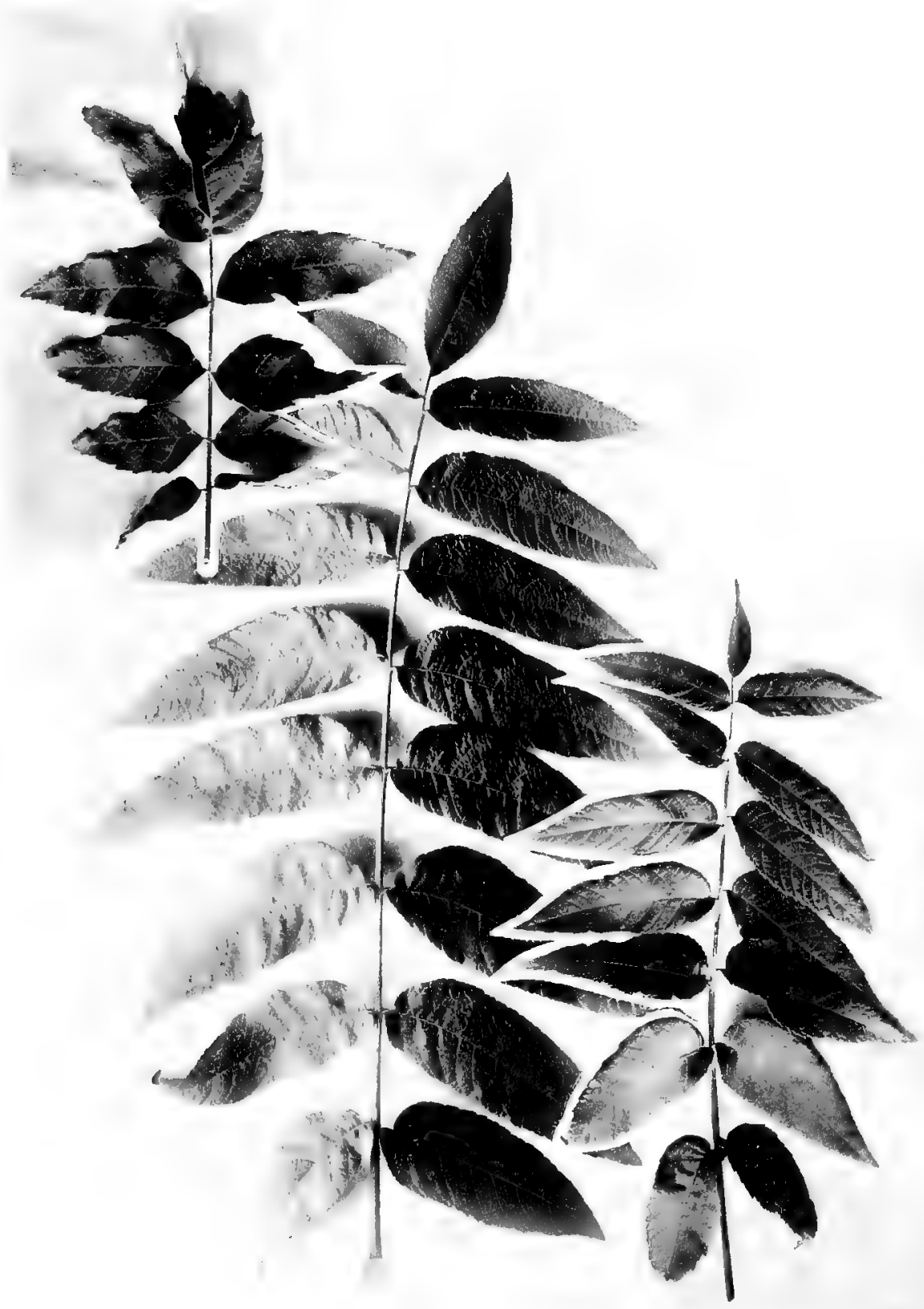

Leaves of Juglans californica $\times$ Juglans nigra, $F_{3}$, to show the variation of the leaves and the leaflets in size and in other qualities. From Luther Burbank's Sebastopol ranch. Twofifths natural size. 



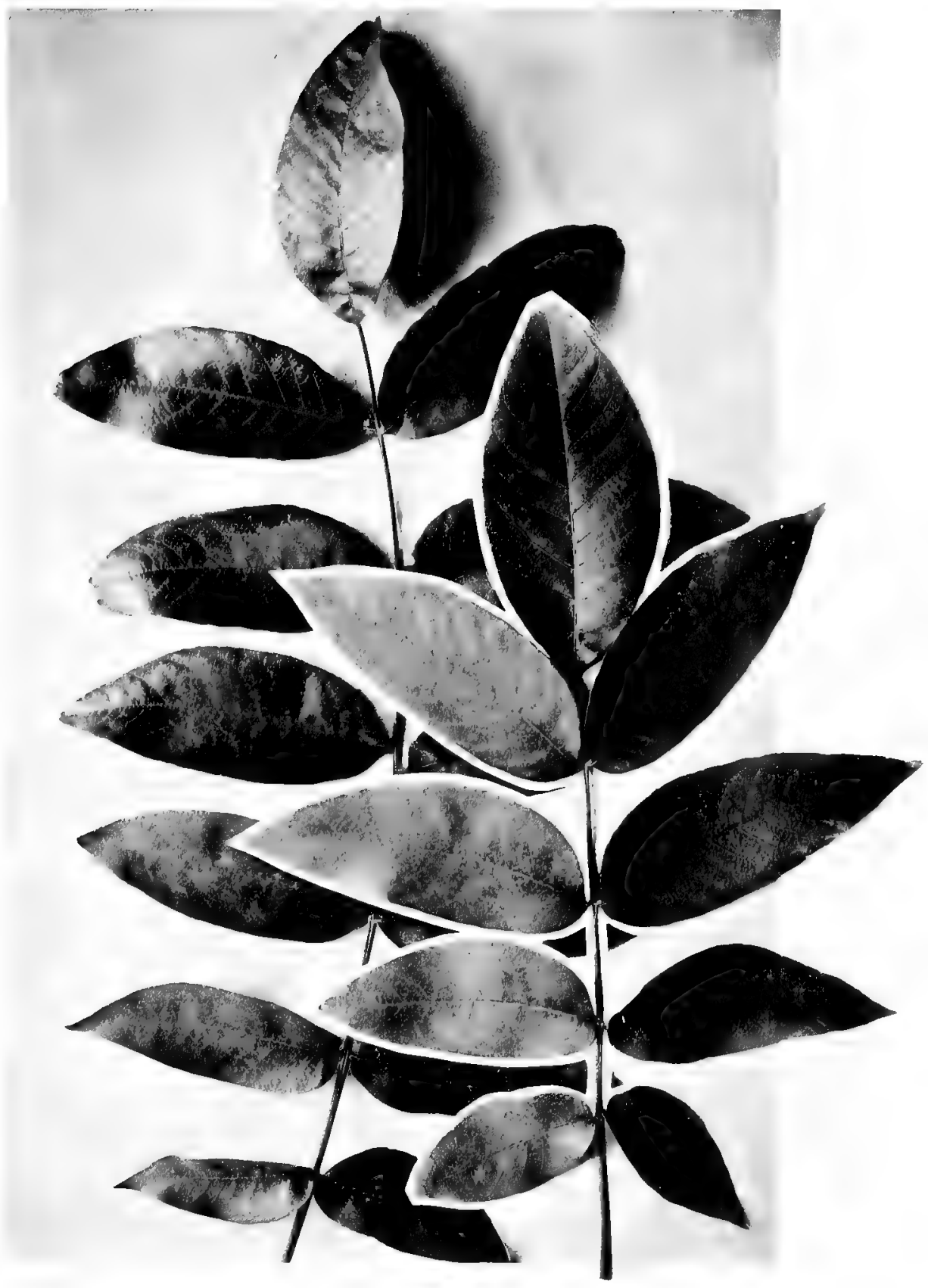

Leaves of Juglans californica $X$ Juglans regia, $F_{1}$, from Santa Rosa, California. The "royal" walnut of Luther Burbank. The figures of this plate, and of the following one, illustrate the range of variation in size of leaves and in the number, size, and other qualities of the leaflets. One-third natural size. 



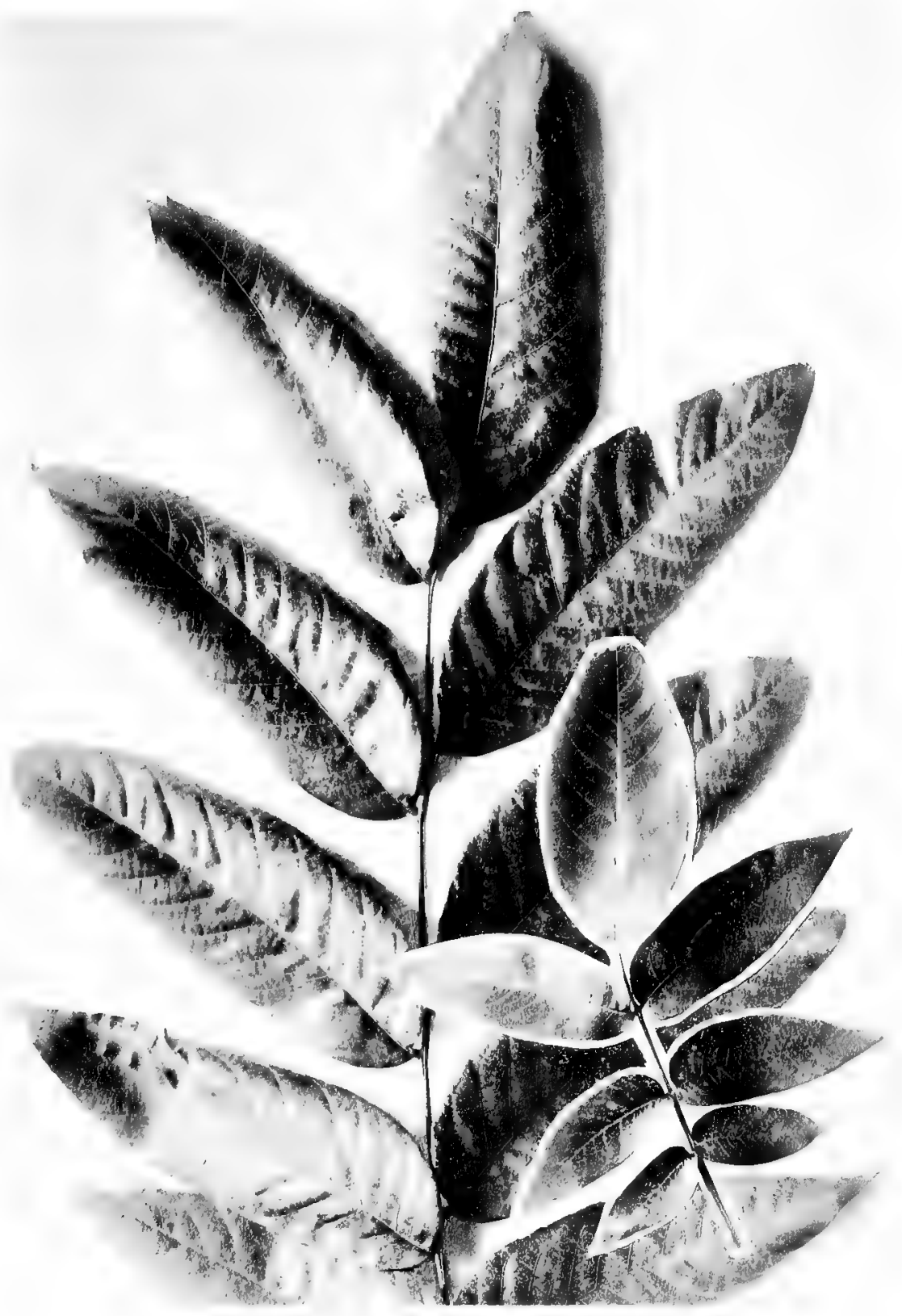

Leaves of Juglans californica $\times$ Juglans regia, $F_{1}$, from Luther Burbank's nursery, Santa Rosa, California, showing the range of the variation of leaves and leaflets. Compare with the preceding plate. One-third natural size. 

seen. Although the development of this trichome was not studied particularly, the material examined indicated that the sequence of cell-divisions may be the same as in the same type of trichome in both pure lines, and thus it conforms with the sequence in cell-divisions in all of the other types of multicellular trichomes in Juglans. Table 17 presents the measurements made on the heads of this form of trichome. The average length of the heads is $22.5 \mu$; diameter, $40.6 \mu$.
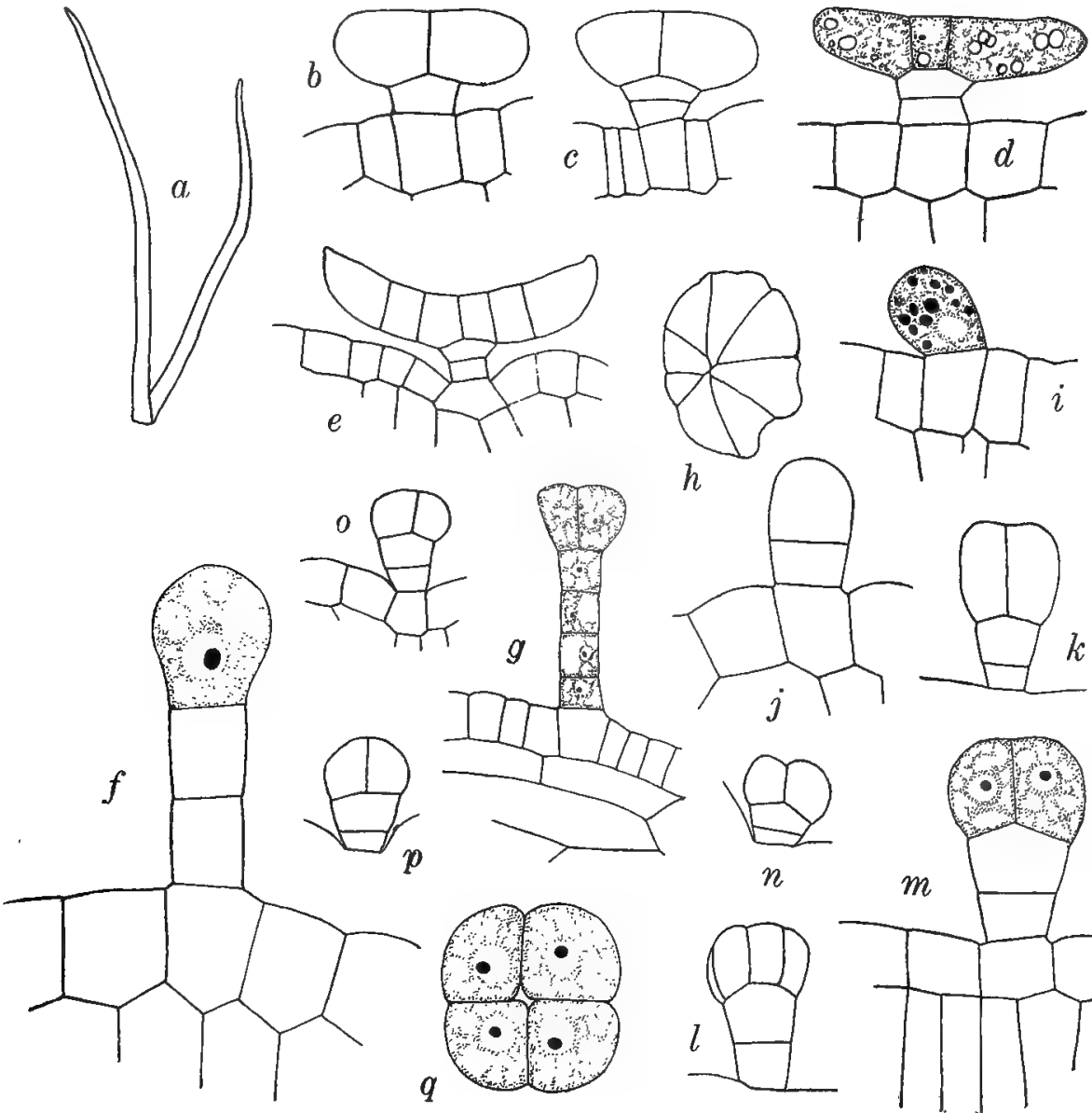

FIG. 10.-Trichomes of Juglans californica $\times T$. vegia, $\mathbf{F}_{1} ; a$, awn-shaped trichomes $(\times 84) ; b$ to $e$ disk-shaped trichomes $(b$ and $d, \times 800) ; c$ and $e, \times 535 ; f$ and $y$, long secreting trichomes $(g, \times$ 535); $h$, transverse section of head of long secreting trichome of type with more than 4 cells in head ( $\times 535) ; i$ to $q$, short secreting trichomes; $i(\times 800)$ and $i(\times 535)$, young trichomes; $k$, trichome from region of veln of lear $(\times 535) ; l$, trichome from dorsal leaf-surface $(\times 535) ; m$, longitudinal section of short secreting trichome $(\times 535) ; n$ to $p$, trichomes from old leaf $(\times 535) ; q_{1}$ transverse section of head of short secreting trichome $(\times 830)$.

The short secreting trichome is multicellular and consists of a 2-celled stalk and a head of 4 cells placed radially, as in both pure lines. Beyond the first division of the young trichome, which is a transverse one, no stages 
in its development were seen. Measurements on the mature trichomes show that the variation in length of the entire organ, but particularly of the head, is in some manner associated with the position occupied by it, as has been repeatedly noted in other forms. And, also, as in the other similar measurements, this variation was found to be in a high degree consistent, which is indicated by the tables of measurements (tables 18 and 19).

TABLE 18.-Length of short secreting trichomes of Juglans californica $\times$ Juglans regia, $F_{1}$. (Trichomes of old leaves.)

\begin{tabular}{|c|c|c|c|}
\hline $\begin{array}{c}\text { Dorsal } \\
\text { surface. }\end{array}$ & $\begin{array}{c}\text { Ventral } \\
\text { surface. }\end{array}$ & $\begin{array}{c}\text { Dorsal } \\
\text { surface. }\end{array}$ & $\begin{array}{c}\text { Ventral } \\
\text { surface. }\end{array}$ \\
\cline { 1 - 1 } & $\mu$ & $\mu$ & $\mu$ \\
46.2 & 25.2 & 42.0 & 29.4 \\
50.4 & 33.6 & 37.8 & 25.2 \\
37.8 & 25.2 & & 33.6 \\
58.8 & 25.2 & & \\
\hline
\end{tabular}

The averages in length of trichomes are: dorsal surface, $45.5 \mu$; ventra1, $28.2 \mu$. Similar results were obtained in another series of measurements, which need not be given, in which the dorsally placed trichomes averaged $35.9 \mu$ and the ventrally placed ones $28.1 \mu$ in length.

TABLE 19.-Measurements on heads of short secreting trichomes of Juglans californica $\times$ Juglans regia, $F_{1}$. (Trichomes of old leaves).

\begin{tabular}{|c|c|c|c|}
\hline $\begin{array}{c}\text { Dorsal } \\
\text { surface. }\end{array}$ & $\begin{array}{l}\text { Ventral } \\
\text { surface. }\end{array}$ & $\begin{array}{c}\text { Dorsal } \\
\text { surface. }\end{array}$ & $\begin{array}{l}\text { Ventral } \\
\text { surface. }\end{array}$ \\
\hline $\begin{array}{c}\mu \\
18.9 \\
21.0 \\
16.8 \\
21.0\end{array}$ & $\begin{array}{l}\mu \\
16.8 \\
\text { I6.8 } \\
16.8 \\
14.7\end{array}$ & $\begin{array}{c}\mu \\
2 \mathrm{I} .0 \\
16.8 \\
\mathrm{I} 6.8\end{array}$ & $\stackrel{\mu}{12.6}$ \\
\hline
\end{tabular}

The averages in length of the heads are: dorsal surface, $18.9 \mu$; ventral surface $15.5 \mu$.

\section{JUGLANS HYBRIDS-SECOND GENERATION.}

The material for the study of the Juglans hybrids and their pure parents, which has been reported on above, was collected in the spring of 1907. This material, unless otherwise specifically noted, was of the first generation. The study was resumed in 1908 for the following purposes: It seemed best to obtain trichomes which were undergoing nuclear division in order to satisfactorily determine the sequence of the cell-divisions, and, also, it seemed best to carry the study of the variation of the trichomes somewhat further, and to learn if possible the relation between the variation of the trichomes and the variation of the plant bearing them.

In selecting the plants for study it was decided to take 2 each of the largest and the smallest of both kinds of hybrids. The largest Juglans 
californica $\times$ Juglans nigra, Nos. 1 and 2, were both about 1.5 meters high; the smallest of this cross, Nos. 3 and 4 , were 40 and $50 \mathrm{~cm}$. high, respectively. The largest specimens of Juglans californica $\times$ Juglans regia, Nos. A and B, were from 3 to 4 meters high; and the smallest, Nos. C and $\mathrm{D}$, were 70 and $150 \mathrm{~cm}$. high, respectively. All of the second-generation plants of either race were of the same age and were apparently growing under similar conditions.

\section{LEAVES OF THE HYBRIDS.}

Fully developed leaves, taken from analogous portions of the plants, were examined and the basal pair of leaflets were photographed (plates 9 and 10). Plate 9 shows the basal leaflets of 4 leaves of plant No. 4, Juglans californica $\times$ Juglans nigra. No. 1 of the figure had 10 leaflets and was 18 cm. long; No. 2 had 11 leaflets and was $29 \mathrm{~cm}$. long; No. 3 had 11 leaflets and was $21 \mathrm{~cm}$. long; and No. 4 had 11 leaflets and was $26.5 \mathrm{~cm}$. in length. Plate 9 shows, also, the basal leaflets of leaves from plant No. 1. Of the figure, No. 1 is of a leaf which was $40 \mathrm{~cm}$. long and had 18 leaflets; No. 2 had 17 leaflets and was $34 \mathrm{~cm}$. in length; No. 3 is of a leaf which had 17 leaflets also and was $36 \mathrm{~cm}$. long; and No. 4 is of a leaf which bore 13 leaflets and was $25 \mathrm{~cm}$. in length. Plate 10, lower figure, is of the basal leaflets of plant No. A, Juglans californica $\times$ Juglans regia. Of the figure, No. 1 is of a leaf which bore 11 leaflets and was $49.5 \mathrm{~cm}$. long; No. 2 is of a leaf which bore 9 leaflets and was $51 \mathrm{~cm}$. long; No. 3 is of a leaf which had 7 leaflets and was $25 \mathrm{~cm}$. long; and No. 4 is of a leaf which had 11 leaflets and which was $55.5 \mathrm{~cm}$. in length. Plate 10, upper figure, is of the basal leaflets of leaves from plant No. C. No. 1 is from a leaf which bore 9 leaflets and which was $34.5 \mathrm{~cm}$. long; No. 2 is of a leaf which had 7 leaflets and was $25 \mathrm{~cm}$. in length; No. 3 is of a leaf which bore 8 leaflets and measured $32.5 \mathrm{~cm}$. in length; and No. 4 is of a leaf which had 8 leaflets and which was $26 \mathrm{~cm}$. in length. The leaves and leaflets of $\mathrm{D}$, which are not shown, were very large, so that only two leaf-bases could be accommodated on the photographic screen at one time. One leaf of D had 12 leaflets and was $37.5 \mathrm{~cm}$. long; and another had 15 leaflets and was $66.5 \mathrm{~cm}$. in length.

There is thus a considerable variation in both series in size of leaves and in number of leaflets, both as regards those of a single individual and those from different plants of the same blood. As for other characters, such as form of leaflet, shape of apex and of base, emargination, and texture or character of surface, there is less variation between the leaves of any individual than between the leaves from different plants. From the examination the following generalizations seem to hold: (1) The largest leaves have also the greatest number of leaflets; (2) the largest leaves are most variable as regards the number of component leaflets. The converse of these is true for the smaller leaves. Except for plant D, also, the largest leaves are borne upon the largest plants; that is, the leaves appear to be an index of the vigor of the plants. The number of leaflets of 
the leaves of both series does not indicate distinct reversion to pure lines in any instance. In Juglans californica $\times$ Juglans nigra, in plant No. 1 , the leaflets numbered from 13 to 18 ; in No. 4, from 10 to 11 . In the pure line californica the leaflets numbered from 19 to 21 , and in nigra from 13 to 21. It therefore appears that the hybrid No. 4, which is small in size, has a smaller number of leaflets than were seen in any leaf of either pure line. In Juglans californica $\times$ Juglans regia, on the other hand, in number the leaflets are intermediate, since in $\mathrm{A}$ they range from 7 to 11 , and in $\mathrm{C}$ from 7 to 9 , while in regia the range is from 5 to 7 . It is, therefore, concluded, as regards the plants which were especially studied of both series, that they do not show reversion in any gross leaf-character to pure lines in any instance.

\section{TRICHOMES OF THE HYBRIDS.}

The material for study was found to be especially favorable for the study of the embryogeny of the trichomes, and, accordingly, an account will be given here of the origin and the development of the leading types. It should be stated at the outset that the cell-divisions were seen in numbers sufficiently large to point to the soundness of the conclusions based on this phase of the investigation.

Five forms of trichomes were found in the hybrid Juglans californica $X$ Juglans nigra and 4 in the other hybrid. The type not common to both is the long secreting trichome already noted as occurring in Juglans nigra and in the first-generation hybrid with nigra blood. In addition to these trichomes, which do not require any additional description here, 3 or 4 abnormal types were seen, all but one of which had already been noted. These will be described below. Since the development of any type of trichome adheres to its peculiar pattern in whichever strain it is found, unless especially stated to the contrary, the subjoined descriptions apply to both lines.

The disk-shaped trichome takes its origin as a squat projection of an epidermal cell and early rndergoes transverse division. The first division of the unicellular trichome thus formed is a transverse one by which the portion which is to become the head is separated from the portion to become the supporting stalk. The second division is a longitudinal one in the end-cel1. This sequence was observed without exception in the diskshaped trichome, and is the sequence of the first two cell-divisions in all of the other multicellular trichomes, save only a single aberrant type which will be mentioned below. In all cases examined the next divisions occur in the head, which appears to become 4-celled at least prior to the transverse cell-division which completes the divisions of the stalk; and trichomes were observed with the fifth and sixth head-cells forming, and one with a head of 8 cells without the final division of the stalk-cell. On the other hand, trichomes were seen which had the stalk fully developed, 

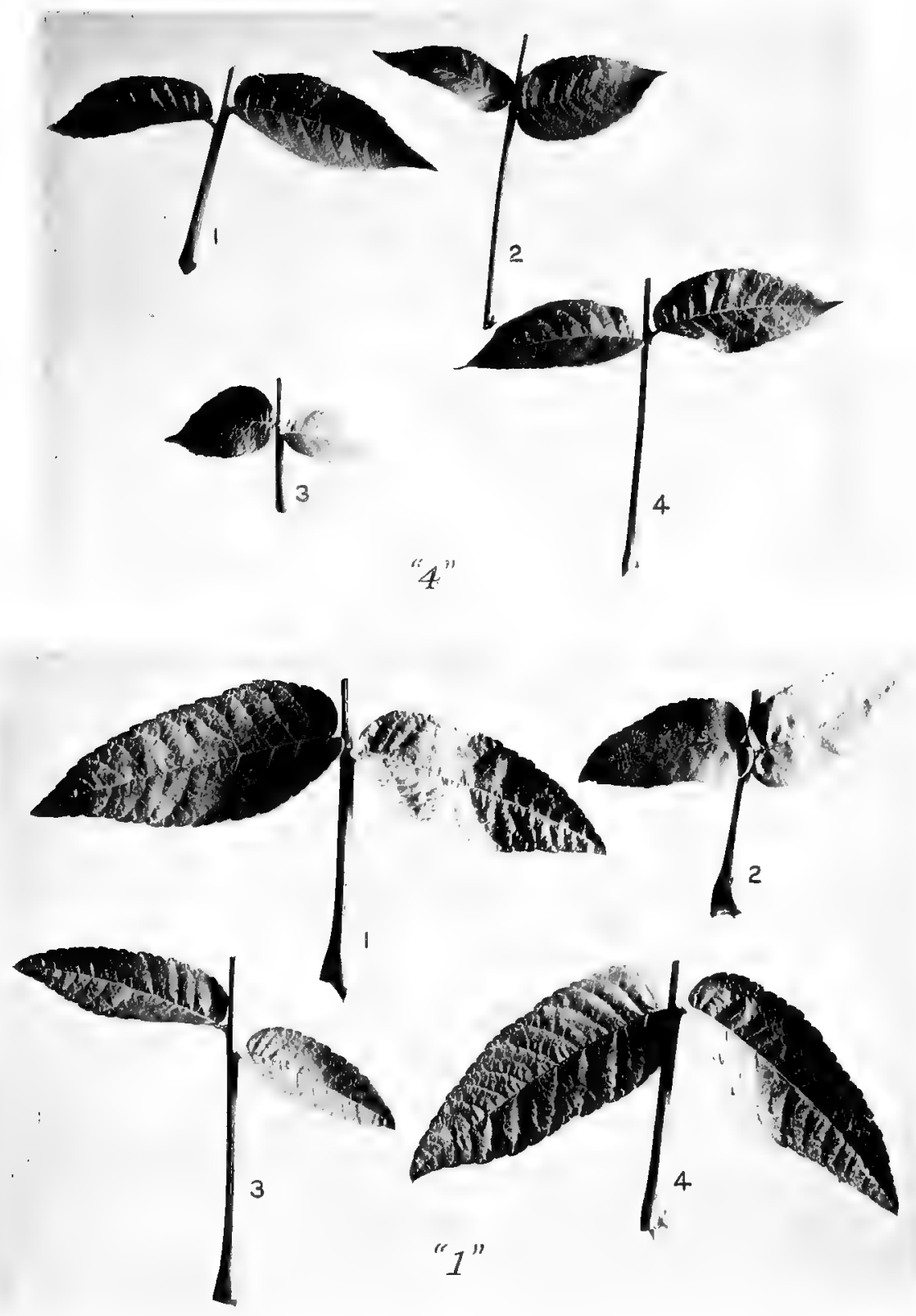

Basal leaflets of leaves of Juglans californica $X$ Juglans nigra, $F_{2}$, in plants " 4 " and "1". One-half natural size. Further explanation in the text 


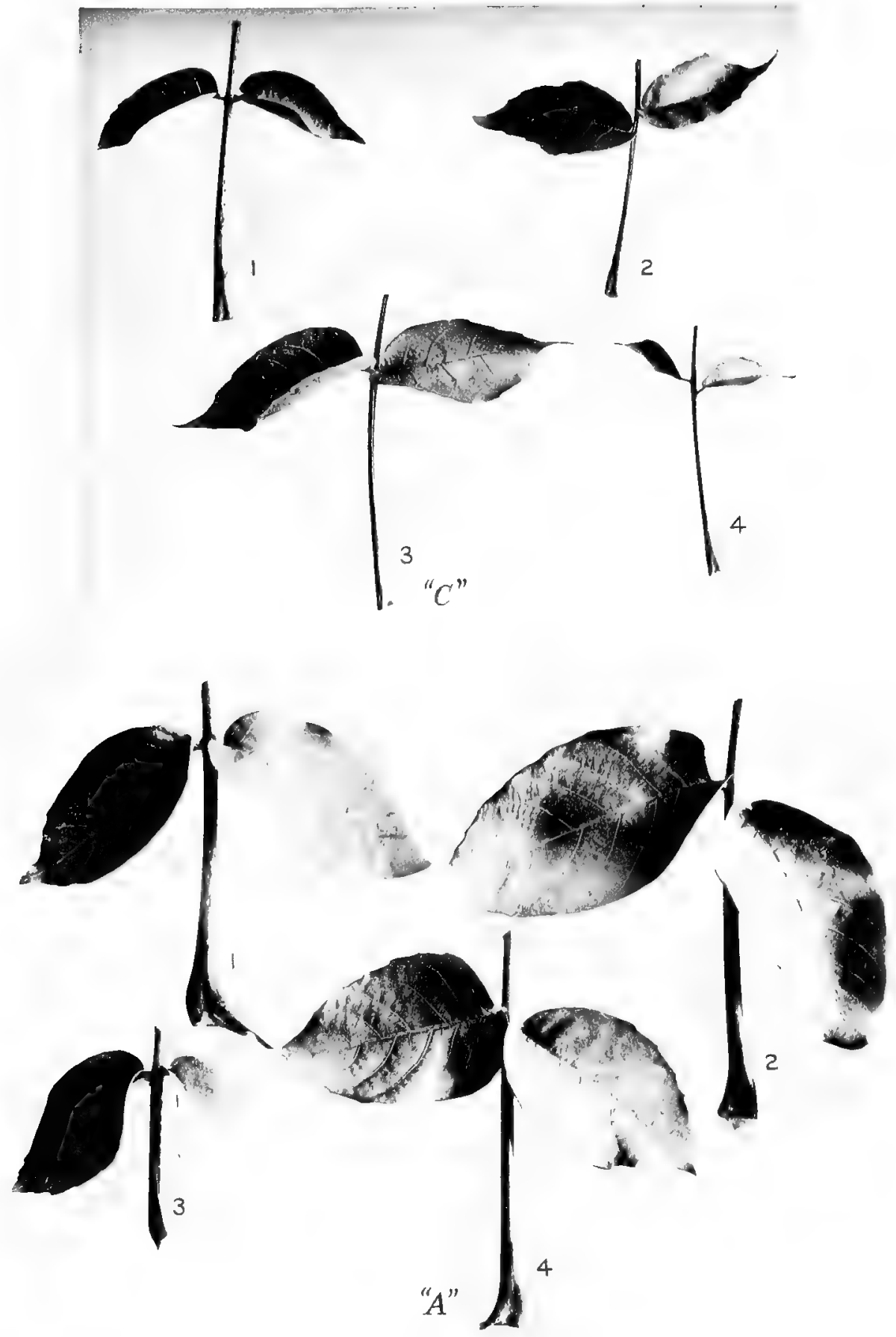

Basal leaflets of leaves of Juglans californica $X$ Juglans regia, $F$, of plants " $C "$ and "A". One-half natural size. Further explanation is given in the text. 
although the head consisted of 6 cells only. It is thought that there may be a relation between the large number of cells of which the mature trichome is composed and the lack of consistency in the sequence of its celldivisions. The head of the mature disk-shaped trichome is composed of at least 32 cells.


FIG. 11.-Trichomes of Juglans californica $\times J_{\text {. nigra, }} \mathrm{F}_{2}$, plant No. 1: $a$, figures showing the cutting off of the young trichome from the epidermis of the leaf; $b$, first cell-division of trichome; $c$, second or longitudinal division of trichome. (All figures $\times 1200$.)

As opposed to the want of uniformity in the cell-division sequence shown in the disk-shaped trichome, the divisions in the short and the longsecreting trichomes follow a perfectly consistent sequence throughout. After the short secreting trichome is cut off from the epidermis it undergoes division by a transverse wall into a terminal cell, which will give rise to the head, and a basal portion, the stalk. The second division occurs in the end-cell and is a longitudinal one. The third division of the trichome is a transverse one in the stalk, by which the divisions in the stalk region are completed. The fourth and the fifth cell-divisions are longitudinal 
ones in the head-cells. The trichome then consists of a head of 4 cells, radially disposed, and a stalk of 2 cells, and cell-division ceases. Although numerous examples of each stage in the development of the trichome were seen, no exception to the sequence as given was noted.

The long secreting trichome in Juglans californica $\times$ Juglans nigra is of two sorts. One type has a stalk of 4 cells and a head of 4 cells, and the
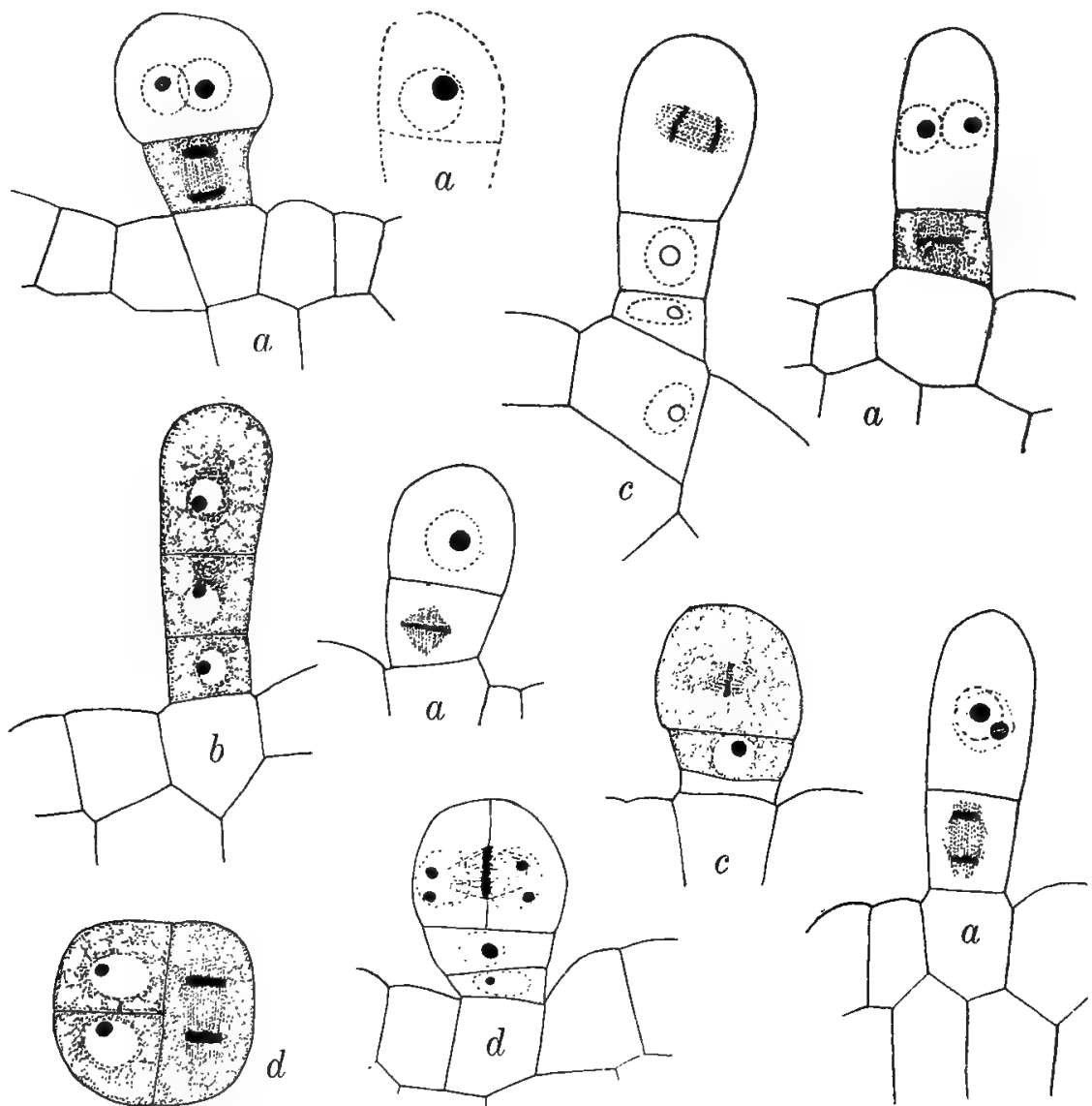

c
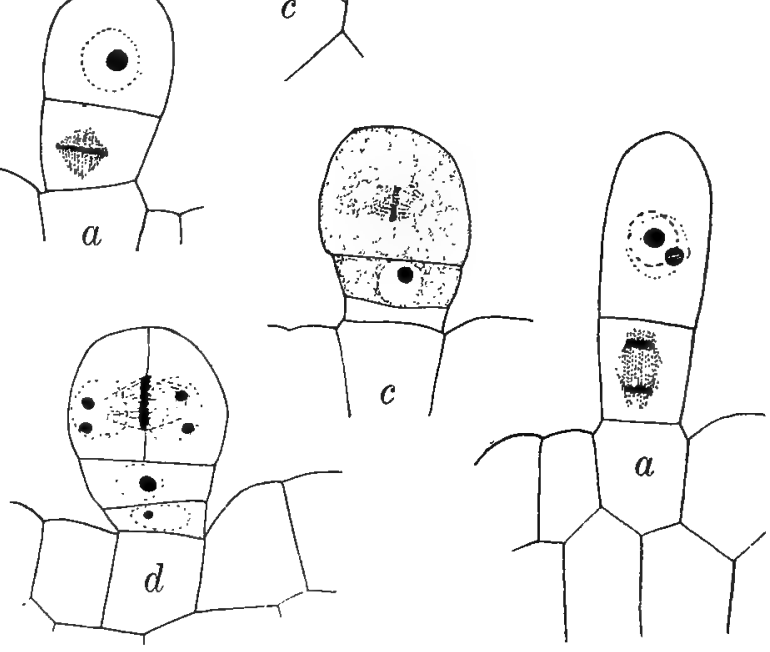

FIG. 12.-Long and short secreting trichomes of Juglans californica $\prec$ Tuglans nigra, $\mathbf{F}_{2}$, plant 1 : $a$, third cell-division of trichome; $b, 4$-celled trichome, of which only 3 cells are shown; $c$, fourth cell-division of trichome; $d$, fifth cell-division shown in transverse and longitudinal sections. (All figures $\times 1200$.)

other type has a stalk of about 8 cells and a head of about 8 cells. The development of the first kind is as follows: The first cell-division of the young trichome is transverse, by which the portion which is to become the head is differentiated from the portion which is to become the supporting stalk. The second division is longitudinal in the head, the third is 
transverse in the stalk, the fourth and fifth are longitudinal in the head. To this point the sequence of divisions of the short secreting and long. secreting trichomes is the same. The sixth division occurs in the upper stalk-cell and is transverse, and the seventh and last cell-division is a crosswall in the lower stalk-cell. The successive divisions are illustrated by the accompanying figures, which also indicate the sequence of cell-divisions in the short secreting trichome.

The results of the study on the second type of long secreting trichome, while not entirely satisfactory, indicate that it is a fundamentally different form than the type with a smaller number of cells. The youngest stages of this trichome either were not seen or could not be identified as belong-


FIG. 13. -Trichomes of Juglans californica $\times$ Juglans nigr $a, \mathrm{~F}_{2}$, plant $1: a$ to $c$, long secreting trichomes, showing sequence of cell-division of stalk; $d$ to $f$. some stages in development of short secreting trichomes. ( $a$ to $c, \times 1200 ; c, \times 840 ; d$ to $f, \times 1200$. Reduced one-fourth.)

ing surely to the trichome. A trichome with 5 cells, of which 2 were of the head, had undergone division of the lower of the 2 stalk-cells. Another trichome having a head of 4 cells had just experienced the division of the lower stalk-cell. That there is some irregularity in the sequence of division is shown by another trichome in which the stalk consists of 4 cells, although the third cell-division of the head is just taking place. The cell- 
divisions of the head and of the stalk appear to take place independently, which is especially and perhaps solely true of rather old trichomes. For example, a trichome was seen which had a head with 7 nuclei, but a stalk with the fifth cell just being cut off, and another trichome was seen which was forming the fifth "or sixth cell in the head, although the stalk consisted of 9 cells.
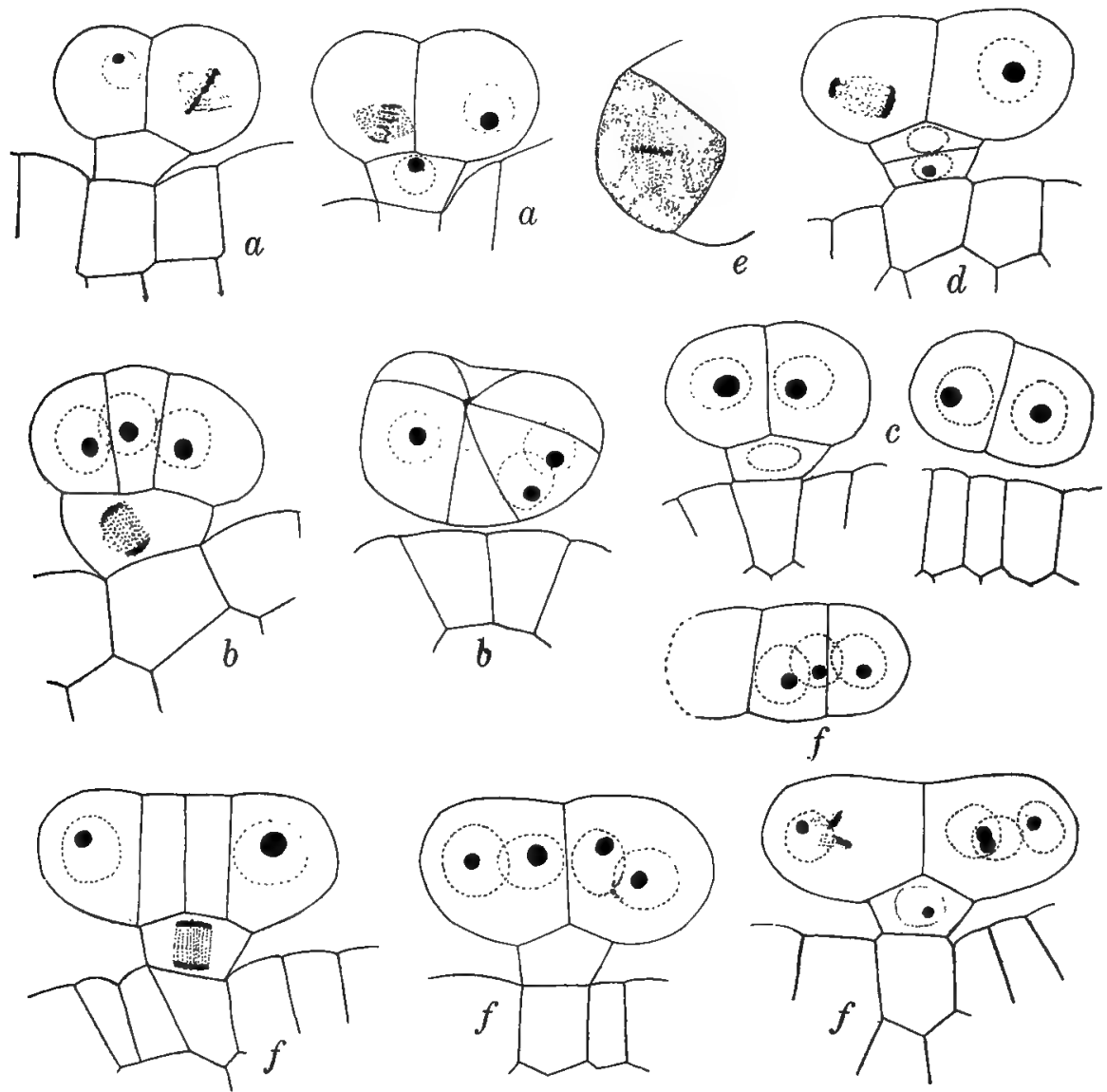

FIG. 14.-Disk-shaped trichomes of Juglans californica $\times$ Juglans nigra, $\mathbf{F}_{2}$, plant 1: $a$, trichome with head consisting of 4 cells, of which 2 are in the process of dividing. and a 1-celled stalk; $b$, trichomes with head of 6 or 7 cells, and a, stalk of 1 cell which is undergolng division; $v$, trichome with 1-celled stalk and 4-celled hefd; $d$, trichome with 2-celled stalk; $e$, transverse section of head to show the formation of octants; $f$, trichome with a head of 7 or 8 cells and a 1.celled stalk. (All figures $\times 1200$ )

Additional evidence as to irregularity in the number of cells making up the larger type of long secreting trichome was observed in the unusually large number of head-cells. A trichome was seen, and is shown in fig. 16, which had a head of 14 cells, although there were only 6 cells in the stalk. 
The reasons for this curious behavior are not apparent, but an explanation may possibly be found in the following facts: The trichome in question was seen only on the veins and is the last of the types to appear, that is, the older leaves only showed its presence, although exactly when in the development of the leaf this type was formed was not learned. Again, the
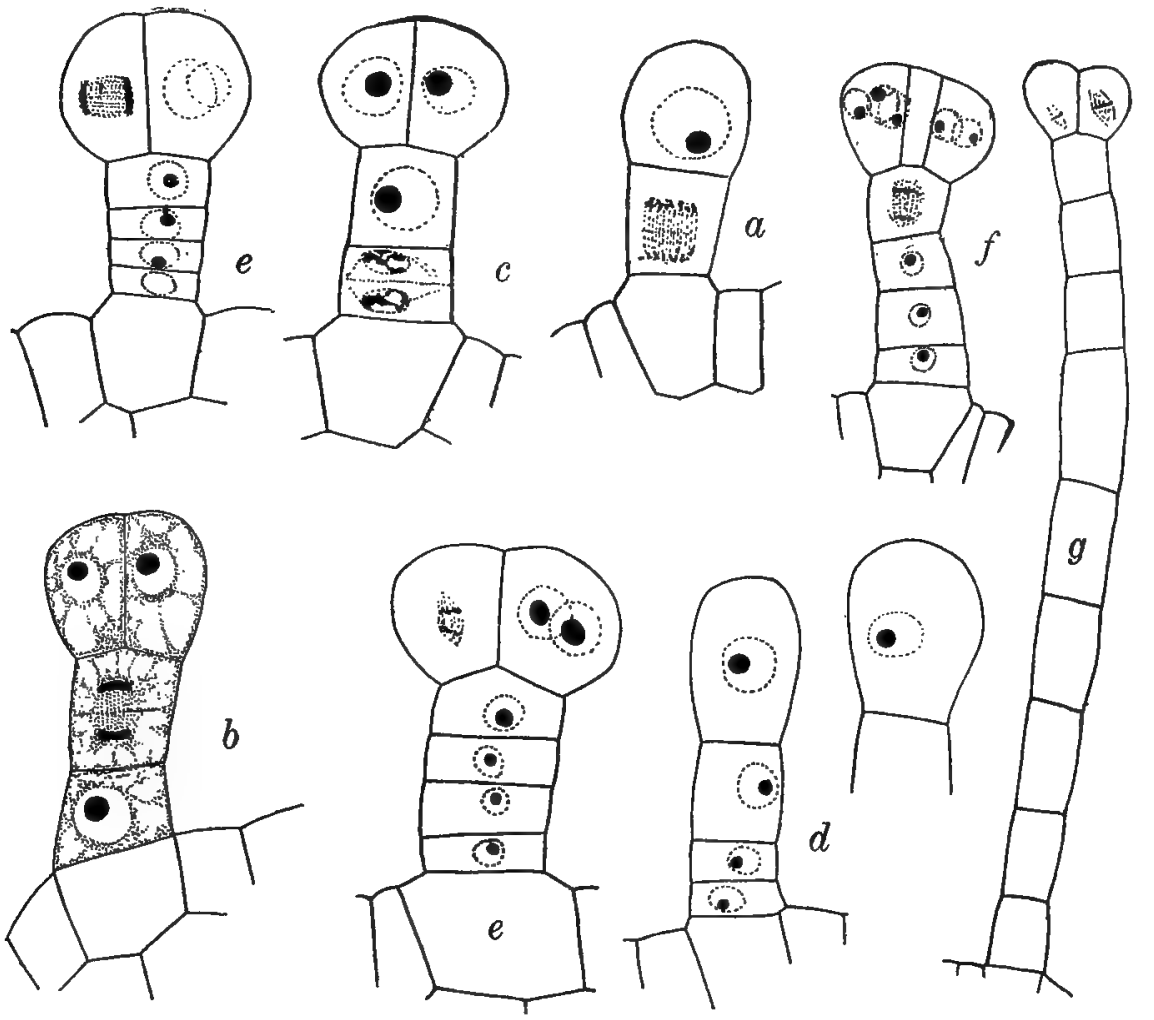

FIG. 15.-Trichomes of Juglans californica $\times$ Juglans nigra, $\mathrm{F}_{2}$, plant 4. (Unless otberwise stated the trichomes are of the type which has a head of more than 4 cells.) $a$, third celldivision of trichome; $b$, long secreting trichome undergoing the sixth cell-division; $c$, second division of the stalk, which thus occurs in different sequence than in the regular type; $d$, same stage as before; $e, 2$ trichomes, showing stalk of 4 cells and the third division of the head; $f$, trichome with a head of 8 cells, of which 3 were seen in the adjoining section, and the ffth stalk-cell in the process of being cut off: $\sigma$, abnormal trichome of long secreting type. (All figures $\times 1200$.)

great irregularity may be owing to the hybrid nature of the plant, as no such inconsistencies were observed in the pure strain nigra. Or, the fact that the number of cells composing the trichome is relatively large may be a factor which should be considered in this connection. This irregularity is all the more striking because of the perfect consistence in the sequence of cell-divisions which was observed in the smaller type of long secreting trichome and in the short secreting trichome as well, 
Aberrant and abnormal types of trichomes were seen in both lines of hybrids. These either were modifications of existing trichome forms or quite new types. Disk-shaped trichomes with more than 2 cells in the stalk, and short secreting trichomes with stalks with 3 in place of 2 cells were observed. The first abnormality noted was seen also in the pure parents, nigra and regia. The abnormal short secreting trichome has been noticed only in the hybrid Juglans californica $\times$ Juglans nigra plants numbered 1 and 2. Abnormal long secreting trichomes were seen, as above indicated, but none which were certainly of the smaller form of this trichome.

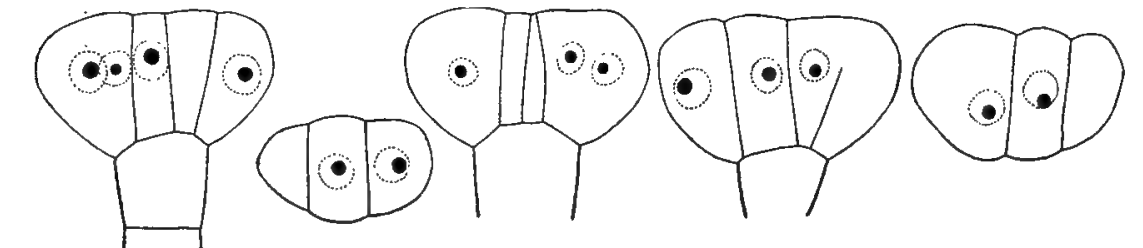

FIG. 16.-Trichome of Juglans californica $\times$ Juglans nigra, $\mathrm{F}_{2}$, plant 4 . Abnormal form of type of trichome which normally has a head of 8 and a stalk of 8 cells. $(\times 1200)$.

An additional type of the abnormal trichome, the irregularity of which is not dependent on the modification of a form now prevalent, was observed several times in Juglans californica $\times$ Juglans nigra and once in the other hybrid. This trichome consists of a cellcomplex in which the customary supporting stalk is wanting; the trichome is made up of 3 tiers of cells, of which each tier has 2 (fig. 18). Thus there are 6 cells in the trichome, of which 2 are terminal, 2 basal, and 2 median. This trichome arises as follows: After the young organ is separated by a crosswall from the epidermis it undergoes longitudinal division (fig. 18, a), in place of a transverse wall, as commonly is the case. The circumstance that the first wall is longitudinal necessarily affects all subsequent cell-divisions in such a manner as to bring about the origin of a new form of trichome. It is of interest to note that the trichome is not a modification of an existing type, but that it appears suddenly and owes its existence to the unique placing of the first wall. It is of interest to note further that should experimentation show that each type of trichome is a unit character, we have here the origin of a character through mutation, in place of through gradual change, as may be the case with certain of the other trichomes whose origin and development have been reported on in this paper. 

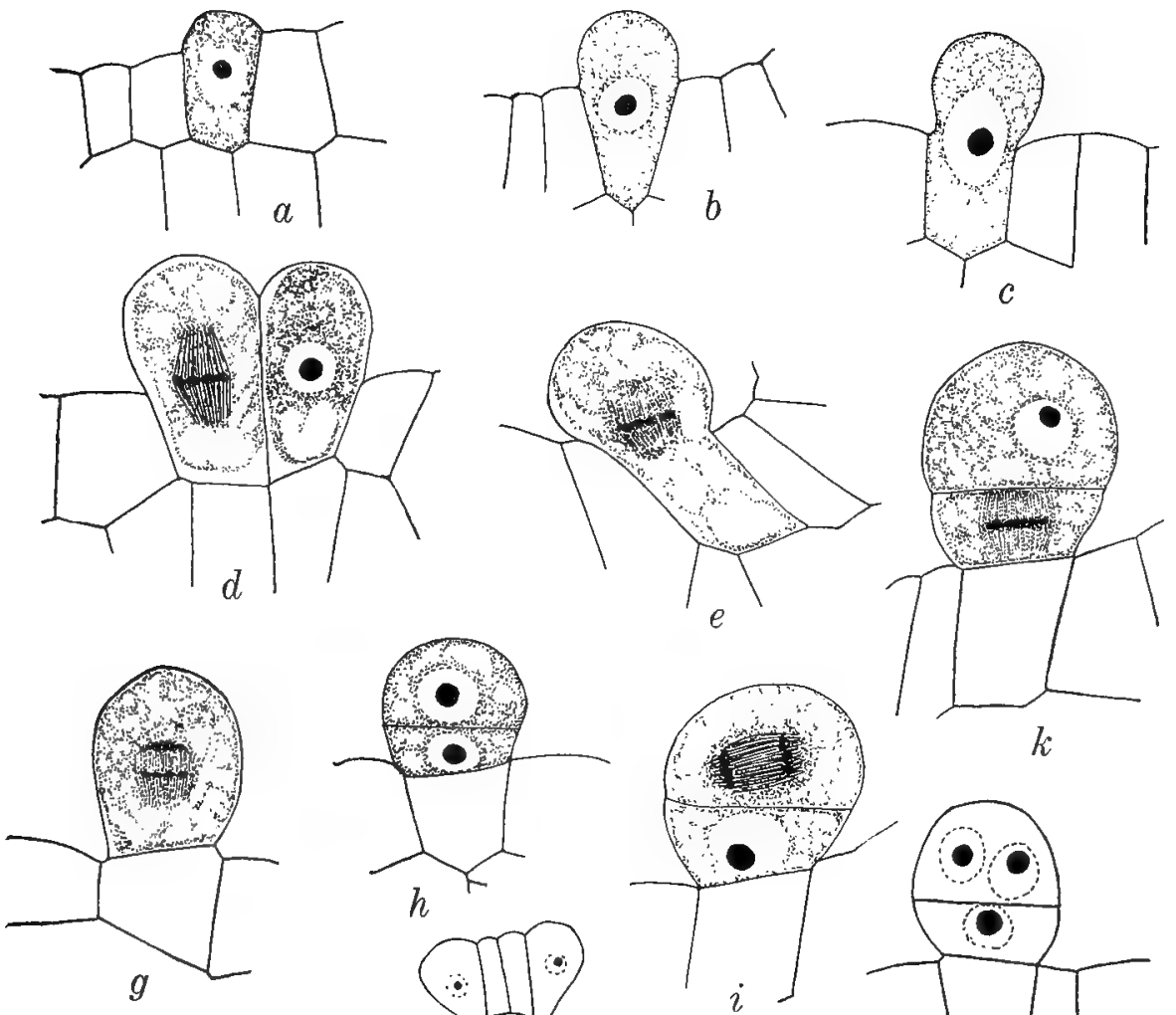

$k$

$h$
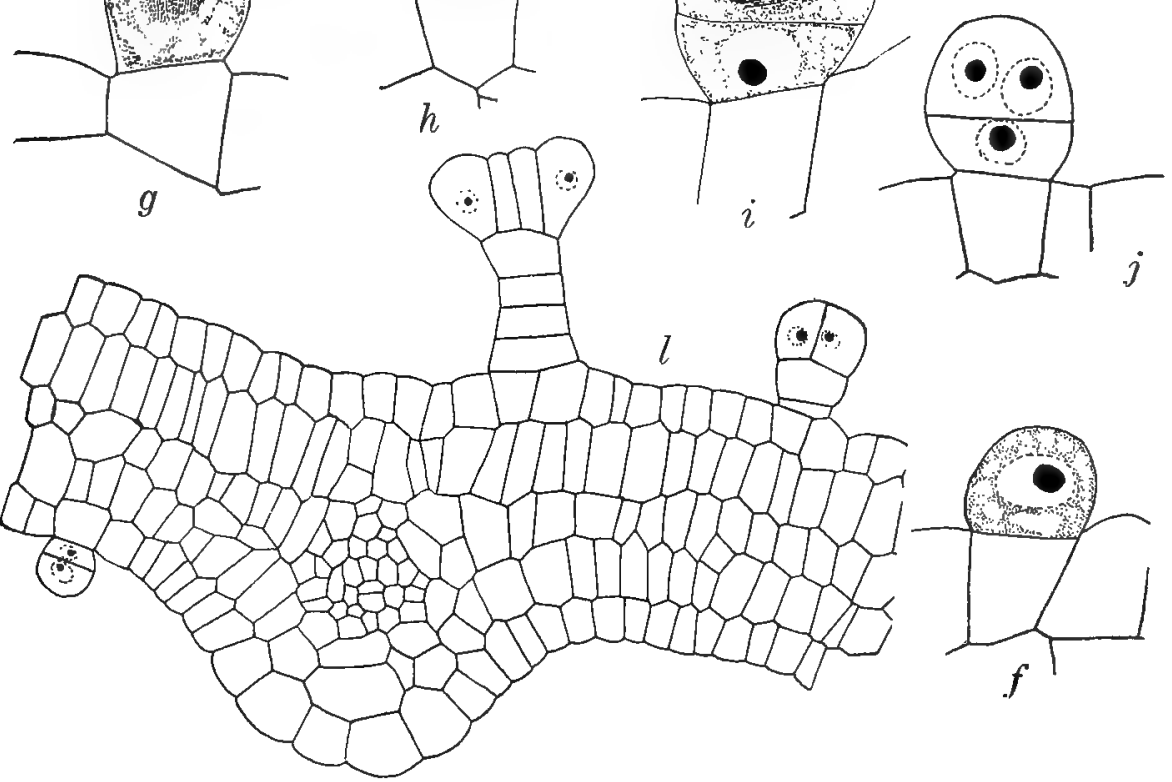

FIG. 17.-Short secreting trichomes of Juglans californica $\times$ Juglans regia, $\mathbf{F}_{2}$, plant $\mathbf{C}: a$ to $c$, origin and growth of trichome previous to separation from epidermis ( $\times 840$ ); $d$ and $e$, separation of trichome rudiment from epidermis $(\times 1200) ; f$, l-celled stage $(\times 840) ; g$, first divison of tricbome $(\times 1200) ; h, 2$-celled trichome $(\times 840) ; i$, second division of trichome; $j, 3$-celled trichome $(\times 1200)$; $k$, third cell-division $(\times 1200) ; l$, transverse section of leaf, showing long and short secreting tri. chomes in place, 


\section{MEASUREMENTS ON THE TRICHOMES.}

The measurements which were made on the multicellular trichomes of the pure lines and first generation of Juglans hybrids indicate, as above shown, considerable variation in size, but comparative study showed also that the causal relations attending the variations might be traced, or at least surmised. Thus the variations were seen to be associated with the age of leaf or with the position occupied by the trichomes on the leaf. These conditions were shown to hold good for all the plants brought under


FIG. 18.-Abnormal and aberrant forms of trichomes of Juglans californica $\times$ Juglans nigra, $\mathbf{F}_{2}$, plant 1 : $a$, young, and $b$ and $c$ mature stages of a new type of trichome (the first cell-division of the trichome is longitudinal in place of being transverse, as is the usual position); $d$ and $e$, abnormal trichomes. ( $a, b$, and $c$ $\times 1200 ; d, \times 840 ; e, \times 535$.

urements to be given presently, therefore, are calculated especially to show two things, namely, (1) whether the trichomes exhibit seasonal variation in size, and (2) whether ancestral characteristics relating to size of trichomes reappear in the second hybrid generation.

\section{Juglans Californica $\times$ Juglans nigra, Second Generation.}

Of the several forms of multicellular trichomes, measurements were made on the disk-shaped and on short secreting types only, and of these the latter offered most favorable material and was mostly used.

The following measurements, in $\mu$, were derived from disk-shaped trichomes taken from the largest and from the smallest of the hybrids. They 
are of diameters only; it was found not practicable to makc a special study of the depth of the head. Disk-shaped trichomes from No. 4, diameters of heads: $79.8,84,84,79.8,92.4,100.8,71.4$; the average diameter is 84.6. The following are the diameters of disk-shaped trichomes from No. 1: 84, 79.8, 79.8, 84, 84, 79.8, 79.8, 79.8, 71.4, 84, 79.8, 71.4; the average is 79.8. The disk-shaped trichomes from the smaller plant, No. 4, average larger than those from the larger one, No. 1. In both instances the trichomes run smaller than in the first generation $(101.1 \mu)$, and also smaller than in the pure species Juglans californica $(107 \mu)$, and appear to be comparable to the trichomes of the pure species Juglans nigra; that is, there appears in this case to be a nigra reversion.

The short secreting trichomes were most numerous, so that accordingly the measurements on them were most complete. Both of the hybrids from which the disk-shaped trichomes just reported on were taken were examined as regards the short secreting trichomes. On the trichomes the following series of measurements were taken: (1) length of entire organ, (2) length, and (3) diameter of the head. The relative age of the leaf and the position occupied on it are both recorded in table 20 .

TABLE 20.-Measurements on short secreting trichomes, hybrid No. $1 . *$

\begin{tabular}{|c|c|c|c|c|c|}
\hline \multicolumn{3}{|c|}{ Dorsal surface. } & \multicolumn{3}{|c|}{ Ventral surface. } \\
\hline $\begin{array}{l}\text { Entire } \\
\text { length. }\end{array}$ & $\begin{array}{l}\text { Length } \\
\text { of head. }\end{array}$ & $\begin{array}{l}\text { Diameter } \\
\text { of head. }\end{array}$ & $\begin{array}{l}\text { Entire } \\
\text { length. }\end{array}$ & $\begin{array}{l}\text { Length } \\
\text { of head. }\end{array}$ & $\begin{array}{l}\text { Diameter } \\
\text { of head. }\end{array}$ \\
\hline${ }_{36.6}^{\mu}$ & $\stackrel{\mu}{18}$ & $\begin{array}{c}\mu \\
29.28\end{array}$ & $\begin{array}{c}\mu \\
20.13\end{array}$ & $\begin{array}{c}\mu \\
12.81\end{array}$ & $\begin{array}{c}\mu \\
20.13\end{array}$ \\
\hline $4 I .24(v)$ & 21.96 & $27 \cdot 45$ & 3 I. I I (v) & 14.64 & 20.13 \\
\hline 28.62 & I6. 47 & 20.13 & 27.45 & 16.47 & 21.96 \\
\hline 30.10 & 16.47 & 18.30 & 27.45 & 16.47 & 23.79 \\
\hline $34 \cdot 77$ & 18.30 & 25.62 & 21.96 & $12.8 \mathrm{I}$ & 18.30 \\
\hline 32.94 & 18.30 & $23 \cdot 79$ & $32.94(v)$ & $21 \cdot 96$ & 21.96 \\
\hline 31.11 & 20.13 & 21.96 & $29.28(v)$ & 18.30 & 23.79 \\
\hline $32 \cdot 94$ & 20.13 & 21.96 & $23 \cdot 79$ & $12.8 \mathrm{I}$ & 18.30 \\
\hline 29.28 & 16.47 & 21.04 & $29.28(v)$ & 14.64 & 21.96 \\
\hline $36.6(v)$ & 25.62 & 29.28 & $3 \mathbf{I} . \mathbf{I}(\mathbf{v})$ & 16.47 & 25.62 \\
\hline & & & $29.28(v)$ & 14.64 & 21.96 \\
\hline & & & $23.79(v)$ & 10.98 & 21.96 \\
\hline & & & $23.79(\mathbf{v})$ & 14.64 & 21.96 \\
\hline
\end{tabular}

*In this and subsequent tables (v) refers to the location on a vein; where the letter is not given the trichome is understood to be placed between the veins.

The averages of these measurements are as follows: Dorsal surface, between veins, entire length, $32 \mu$; length of head, $18 \mu$; diameter of head, $24.7 \mu$. Ventral surface, between veins, entire length, $24 \mu$; length of head, 14.2; diameter of head, $20.5 \mu$; on veins, entire length, $28.7 \mu$; length of head, $15.9 \mu$; diameter of head, $22.5 \mu$.

The leaves of both series of hybrids were not entirely mature; they were in each instance $84 \mu$ in thickness. 
Another study on the dimensions of the trichomes of No. 4, as will appear directly, gave somewhat different results. The leaves were of the same thickness as those reported on above. The measurements, of which there were 60, may be disregarded; the results are as follows: Dorsal surface, entire length, $31.47 \mu$, length of head $16.5 \mu$, diameter of head $21.6 \mu$; ventral surface, entire length, $29.2 \mu$; length of head $16.2 \mu$, diameter of head $22.6 \mu$. Thus the length of the trichomes from the dorsal surface is about the same in both cases, but the size of the heads is in the latter instance somewhat greater. The dimensions of trichomes from the ventral surface of the former are nearly the same as those from between the veins of those last given. In each instance the same relation of length to diameter of head is almost exactly held.

TABLE 21.-Measurements on short secreting trichomes, hybrid No. q.



*Attached to leaf-surface in close relation to a vein. tThese trichomes occurred on the same vein.

\$These trichomes were on opposite sides of the leaf and very near a vein.

The averages are as follows: Dorsal surface, entire length, between veins, $33.8 \mu$, length of head $16.44 \mu$, diameter of head $25 \mu$; on veins, entire length $41.84 \mu$, length of head $18.3 \mu$, diameter of head $23.5 \mu$; ventral surface between veins, entire length $31.1 \mu$, length of head $19 \mu$, diameter of head $19.70 \mu$; on veins, entirc length $35.5 \mu$, length of head $15.16 \mu$, diameter of head $19.26 \mu$.

The leaves studied were not fully developed; they were $84 \mu$ in thickness. If we compare the average measurements of hybrids 1 and 4 we shall get the following results: (1) trichomes taken on the dorsal surface, between veins, are longer in plant 4 than in plant 1 , and the heads also are larger, but they retain similar proportions; (2) those between the veins on the ventral surface of plant 4 are also longer than in 1 , and the heads are longer but of less diameter (califomica character ?); (3) on the veins the trichomes of 4 are larger than those on the veins of 1 , but the heads are shorter and of less diameter, that is to say, the trichomes of hybrid No. 4 
are uniformly larger than those of hybrid No. 1, which is a larger plant. The form of the heads is, with one exception, the same in both series of plants.

It has been noted, in the tables and the averages, that the heads of the trichomes are wider than long, and this also is a character that distinguishes nigra from californica. The relative form of the heads of the short secreting trichomes in the pure species and the form of the head in this, the second-generation plant No. 4, are shown in the figures. Therefore it appears that we here meet a well-defined instance of reversion to the pure species nigra.

\section{Juglans Californica $\times$ Juglans Regia, Second Generation.}

Measurements were made on trichomes taken from the leaves of plants $\mathrm{A}$ and $\mathrm{C}$, which were among the largest and smallest, respectively, of those of this generation. The study was carried out mainly on the short secreting trichomes, for the reason that this type was most numerous, although some measurements also were made on the disk-shaped trichomes. The long secreting trichomes in the material examined were not present in numbers large enough to make a satisfactory study of them.

TABLE 22.-Measurements on short secreting trichomes, hybrid No.A.

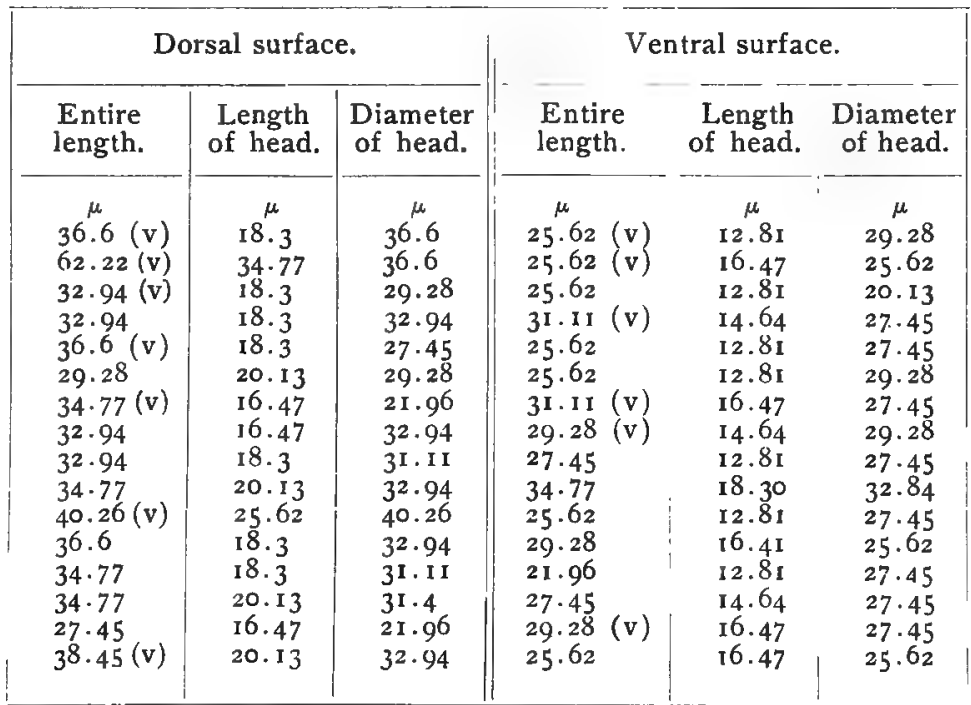

The averages are as follows: Dorsal surface, entire length, between veins $32.94 \mu$, length of head $18.5 \mu$, diameter of head $30.4 \mu$; on veins, entire length $40.2 \mu$, length of head $21.7 \mu$, diameter of head $32.1 \mu$; ventral surface, between veins, entire length $27.04 \mu$, length of head $14.4 \mu$, diameter of head $27.8 \mu$; on veins, entire length $28.67 \mu$, length of head $15.25 \mu$, diameter of head $27.75 \mu$. 
Following are the diameters, in $\mu$, of disk-shaped trichomes from leaves of plant A: $54.6,67.2,67.2,63,58.8,67.2,58.8,67.2,71.3,63,71.3,67.2$, $71.3,71.3,71.3$, which average $66 \mu$. The following dimensions, in $\mu$, were obtained of disk-shaped trichomes from $\mathrm{C}: 67.2,71.3,67.2,67.2$, $67.2,63,63,67.2,71.3,71.3,67.2$, which average $67.5 \mu$. The diameters of the trichomes of the larger plant $A$ and those of the smaller plant $C$ are nearly the same. The trichome appears not to revert to either pure line, but holds an intermediate position, as in the first generation.

Dimensions of the short secreting trichome of both of the plants $A$ and $\mathrm{C}$ were especially noted. These included the entire length of the trichome, the length, and the diameter of the head. Attempt was made to get leaves which were of approximately the same age, but it happened that those of $\mathrm{A}$ were $10 \mu$ thicker than those of $\mathrm{C}$. The former was $94 \mu$ and the latter $84 \mu$ in thickness. It will be recalled that the leaves of hybrids numbered 1 and 4 were also $84 \mu$ in thickness.

The measurements show that the length of the trichomes of the dorsal surface, as well as both dimensions of the heads of trichomes from this surface, are larger than the corresponding dimensions of trichomes from the opposite leaf-surface, and also that all of the dimensions of trichomes from the veins are greater than the dimensions of trichomes from between. them. The fact of reversion is not clear. The diameter of the heads of the hybrid trichomes is considerably greater than that of either californica or regia, and the length of the head is intermediate between the lengths of the heads of this trichome in the two pure species. The proportions of the head of the hybrid, on the other hand, are practically the same as the proportion in the pure species regia. It is to be noted that the form of the head is nearly as in the first generation of this hybrid (fig. 19).

TABLE 23.-Measurements on short secreting trichomes, hybrid No. C.

\begin{tabular}{|c|c|c|c|c|c|}
\hline $\begin{array}{l}\text { Entire } \\
\text { length. }\end{array}$ & $\begin{array}{l}\text { Length } \\
\text { of head. }\end{array}$ & $\begin{array}{l}\text { Diameter } \\
\text { of head. }\end{array}$ & $\begin{array}{l}\text { Entire } \\
\text { length. }\end{array}$ & $\begin{array}{l}\text { Length } \\
\text { of head. }\end{array}$ & $\begin{array}{l}\text { Diameter } \\
\text { of head. }\end{array}$ \\
\hline & $8^{\mu}$ & $\mu$ & $\mu$ & $\alpha_{\mu}$ & $\mu$ \\
\hline $36.6(v)$ & 18.3 & $27 \cdot 45$ & 25.62 & 16.47 & 25.62 \\
\hline 3I.II & 16.47 & 27.45 & $29.28(\mathrm{v})$ & 14.64 & 29.28 \\
\hline $34 \cdot 77$ & 18.3 & 23.79 & 27.45 & 14.64 & $27 \cdot 45$ \\
\hline $45.75(v)$ & 20.13 & 29.28 & $36.6(v)$ & 21.96 & $27 \cdot 45$ \\
\hline $40.26(v)$ & $18 \cdot 3$ & $23 \cdot 79$ & $43.92(\mathrm{v})$ & 21.96 & $34 \cdot 77$ \\
\hline $42.09(v)$ & 20. I3 & $27 \cdot 45$ & 32.94 & 20.13 & $23 \cdot 79$ \\
\hline $36.6(v)$ & 30.13 & 29.28 & 27.45 & 16.47 & 3I.II \\
\hline $40.26(v)$ & 21.96 & $23 \cdot 79$ & 27.45 (v) & $0_{4} .64$ & 21.96 \\
\hline $27.45(\mathrm{v})$ & 18.3 & 21.96 & $34 \cdot 77(v)$ & 18.3 & $27 \cdot 45$ \\
\hline 36.6 & 20.13 & $29 \cdot 45$ & $34.77(\mathrm{v})$ & 18.3 & 29.28 \\
\hline 36.6 (v) & 16.47 & 25.62 & $\mathbf{2 3} \cdot 79$ & 10.96 & \\
\hline $3^{8} .43(\mathrm{v})$ & 20.13 & $3^{2} .94$ & 21.96 & 14.64 & 21.96 \\
\hline & $18 \cdot 3$ & 29.28 & 3I.II & 14.64 & 25.62 \\
\hline 34.77 (v) & 18.3 & $3 \mathrm{I} \cdot \mathrm{II}$ & 3I.II & 16.47 & 29.28 \\
\hline 29.28 & 14.64 & 25.62 & $42.09(v)$ & 23.79 & $27 \cdot 45$ \\
\hline $32.94(v)$ & 16.47 & 20.14 & $32.94(v)$ & 18.3 & 29.29 \\
\hline
\end{tabular}


The averages of the measurements are as follows: Dorsal surface between veins, entire length $33.5 \mu$, length of head $17.6 \mu$, diameter of head $27.4 \mu$; on veins, entire length $37.69 \mu$, length of head $19 \mu$, diameter of head $26 \mu$; ventral surface, between veins, entire length $27.6 \mu$, length of head $15.5 \mu$, diameter of head $26 \mu$; on veins, entire length $35.2 \mu$, length of head $18.9 \mu$, diameter of head $28.3 \mu$.

From the averages it appears that the trichomes which occur on the veins are larger than those between them, and that those on the dorsal
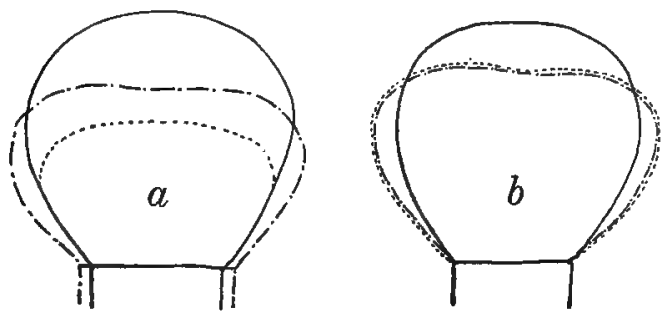

FIG. 19.-Diagrams, based on numerous measurements, showing reversion of the heads of short seereting trichomes in the second-generation Juglans hybrids. $a, \pi$ californica $\times J$. regia, plant A. Legend: solid line (-), I. californica; dotted line $(\ldots \ldots \ldots), J$. regia; broken line (-- - ), hybrid. $b, J$. californica $\times J$. nigr $\alpha$, plant 1, Legend: solid line (-) J. califunica; dotted line (.......), J. nigra: broken line $(--\cdots)$, hybrid.

\section{Th hybrid numbered $A$, so in $C$, the fact of $\mathrm{A}$.}

In hybrid numbered $\mathrm{A}$, so in $\mathrm{C}$, the fact of reversion to the pure lines is not clear. The heads of the trichomes of the hybrid are broader as well as shorter than those of regia, but they are smaller in these dimensions than the heads of californica. This condition is shown diagrammatically by fig. 19, which is based on the average measurements of the two pure lines and the hybrid. It will be seen that, in form at least, the heads of the trichomes of the hybrid agree very well with the pure species regia, to which they appear to revert.

\section{GENERAL COMPARISON OF TRICHOMES IN THE PURE SPECIES AND HYBRIDS OF JUGLANS.}

The study of the trichomes of the Juglans hybrids and pure species has been carried on with the purpose of comparing not only the mature organs of the hybrids with those of the parents, but also their origin and deve1opment step by step so far as possible. As the study progressed it was found that material for comparison of mature structures was abundant enough, but material for the observation of the developmental stages, which depends on the presence of mitotic figures, was not at a11 easy to get, so that, as the second-generation hybrids were fairly rich in this particular, the account of the development of the trichomes is practically confined to plants of this, the second, generation. 
Four types of trichomes were seen in the pure species californica, nigra, and regia, and in the hybrids Juglans californica $\times$ Juglans nigra and Juglans californica $\times$ Juglans regia, but in the species nigra and the hybrid into which it enters an additional form of trichome, not observed in the other plants, was also seen. In addition to these, the regular types, there were also abnormal forms of trichomes which were clearly modifications of those more commonly present, and one type which was essentially different from those most abundant. With one exception all types of trichomes were multicellular and glandular.

In the second generation of the hybrid Juglans californica $\times$ Juglans nigra, two of the multicellular trichomes, namely, the short and the long secret-

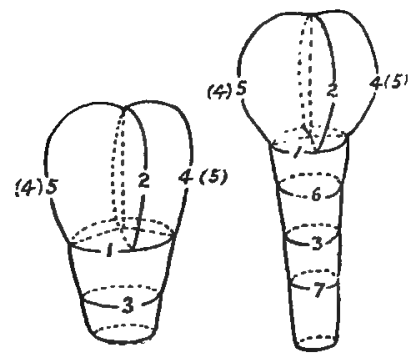

Frg. 20.—Sequence in cell-division in the short and the long secreting trichomes of Juglans. The num. bers give the succession of cellwill formation in proper sequence. ing trichomes, are composed of 6 and 8 cells, respectively. The sequence of cell-divisions up to the formation of 6 cells is identical, hence the larger trichome may be regarded as a further developed short secreting one, or vice versa, the smaller type may be held to represent an arrested stage in the development of the long secreting trichome (fig. 20). It does not seem probable that both have descended from a common ancestor (so to speak) which had intermediate characters, since the simplicity of the structure seems to preclude this. Of the two other types of multicellular trichomes which occur in the hybrid, and which have from 16 to 32 or more cells, the disk-shaped trichome agrees in the sequence of its divisions with the two trichomes mentioned above in the first two divisions only, and the fourth type of multicellular trichome agrees in sequence with the two trichomes mentioned in the first 3 and possibly the first 5 cell-divisions.

The sequence of all of the cell-divisions in the 6-celled and the 8-celled trichomes was found, by repeated observations, to be perfectly consistent, and the first two or first three divisions also in the larger trichomes were seen to be consistent for the particular type of trichome, but the subsequent cell-divisions of the larger trichomes appeared not to occur in consistent sequence. The last statement is made with reservation, however, as further and careful study of later stages, which would be a difficult task, might reveal an unexpected regularity of cell-division in such trichomes.

The abnormal trichomes were of the following types: they were short secreting trichomes with one additional stalk-cell, or a disk-shaped trichome with 1 or 2 additional cells in the stalk. There seemed also to be abnormal forms of the long secreting trichome in which the stalk had an unusually large number of cells and the head also had a larger number of 
cells than normal. All of these abnormal trichomes were found on the veins of leaves, but were not very abundant. An additional form of abnormal trichome, which was plainly different from any trichome to be found on the Juglans hybrid, and pure lines as well, was found in $\mathrm{F}_{2}$ of both hybrids. This type had a stalk 2-ranked in place of 1-ranked, as usually is the case. The head also was 2 -celled and not 4 or more celled, as in the other multicellular trichomes. This type had its origin in a trichome rudiment which is divided at first longitudinally, in place of transversely, as is the case in the other trichomes. From this circumstance alone we here observe the beginning of a new type of trichome, not by the modification of a preceding form, as is the case of the 6-celled and the 8-celled trichomes above mentioned, and probably the other multicellular trichomes also, but by a sudden change in the sequence of cell-division.

Numerous measurements, which were made on the length of the trichomes and the length and the diameter of the heads, showed that there is considerable variation in size, and further study revealed a definite relation between this variation and the position occupied by the trichome, or the age of the member bearing it. By keeping these facts in mind, just comparisons could be made between trichomes placed in analogous locations and under similar conditions, which otherwise would not be possible. The general facts of the variation as induced by such environmental conditions may be expressed briefly thus: the trichomes and the heads of trichomes which are situated on the veins of the leaves or in their immediate vicinity are usually larger than trichomes of the same sort which occupy a position between or relatively remote from the veins of the same leaf; trichomes on young members are usually larger than those on members that are old; trichomes from the dorsal surface are usually larger than the corresponding trichomes from the ventral surface of the same leaf.

As regards reversion to ancestral characteristics, the trichomes of such of the first-generation hybrids as were studied were intermediate in size and hence did not exhibit reversion, and those of the second generation were not uniform in this particular. It is probable that study of a large number of plants of the second generation will show alternative inheritance. In the second-generation hybrid, in which nigra enters, the disk-shaped and the long secreting trichomes both show nigra characters and may be regarded as reverting to that pure species, while as to these trichomes in the hybrid in which regia enters the inheritance is not so clear. In this case, the diskshaped trichomes of the hybrid are intermediate in size between those of californica and regia, while the heads of the short secreting trichomes have the form of those in regia, but are much larger. Should the short secreting trichome of the Juglans californica $\times$ Juglans regia be considered a reversion, as probably is the case, we here have another indication that 
a trichomal system should not be taken together as a single unit, but should be separated into as many units as there are trichome types.*

The hybrid plants of the second generation which were taken for study were among the largest and among the smallest of all of this generation, and all were of the same age and apparently had had an equal chance in life. The opportunity was thus given to observe the relation between vigor of the plants as a whole and the size of the trichomes which they bore. The results are contradictory, and because of this fact the value of the trichome in a study of this character is shown to be great, as it probably is less influenced by conditions attending general plant development than other organic systems of the plant. The disk-shaped trichomes, and the short secreting trichomes also, of plant 4 were somewhat larger than those in the larger plant numbered 1 of the hybrid Juglans californica $\times$ Juglans nigra, while these trichomes in plant $\mathrm{A}$ and in plant $\mathrm{C}$ of the other hybrid, like and like, were practically of the same size.

* See page 1 I. 


\section{CONCLUSIONS AND RESULTS.}

The 11 different species and the hybrids derived from them, which were employed in the course of the investigation, represent an interesting range of habits and life conditions as well as types of variation and reversion.

The pure species are both arborescent (Juglans) and herbaceous. The herbaceous plants are annuals (Papaver somniferum, Solanum villosum), biennials (Oenothera lamarckiana, Oenothera cruciata), or perennials (Solanum guinense, Papaver orientale, Papaver pilosum).

The feature of fertility or sterility of the hybrids is as follows: Those wholly fertile are Solanum villosum $\times$ Solanum guinense (5 generations have been observed); Oenothera lamarckiana $\times$ Oenothera cruciata ( 3 and more generations have been studied with regard to this characteristic); Juglans californica $\times$ Juglans nigra. The wholly sterile hybrids are Papaver somniferum $\times$ orientale. Juglans californica $X$ Juglans regia and Papazer somniferum are partly fertile.

Several types of reversion are known among the hybrids, so far as this feature has received particular study, and further observation would probably reveal still other reversion characteristics.

Two hybrids, Oenothera lamarckiana $\times$ Oenothera cruciata ${ }^{*}$ and Solanum guinense $X$ Solanum villosum, are fixed forms in the first as well as the succeeding generations, so far as observed. In the Oenothera hybrid there is a mingling of the parental characters, no new character appearing; but the Solanum hybrid exhibits, in the fruit, a condition not found in either pure parental species. The Papaver and the Juglans hybrids, first generation, are extremely variable as regards the leaf-characters. The type of reversion in Juglans hybrids, of the second and third generations, has not been closely studied, but may be Mendelian. The Mendelian characteristic of dominance was not observed in any hybrid.

Two general forms of trichomes were seen in nearly all of the hybrids and the pure species-living forms (which are glandular) and non-living forms. After some study it was learned that the living forms of trichomes had more of interest for the subject in hand, so that for the most part this paper reports the behavior of such trichomes. In the Oenotheras the glandular trichomes are unicellular, but in the other species they are multicellular, and in certain of them, particularly in Juglans, the development of the trichomes was followed and was found of value for comparative purposes.

As repeatedly observed during the course of the study, the trichomes were found to present considerable range in size, which is meant to apply to any type, and this was found to be the case both in pure lines and in hybrids. The extremes in variability were no more marked in the latter

*Mutations, Variations, and Relationships of the Oenotheras, by MacDougal, Vail, and Shull. Carnegie Institution of Washington Publication No. 8I, I907. 
than in the former case, which was somewhat unexpected, inasmuch as in certain instances (Juglans californica $\times$ Juglans nigra, for example) the leaves of the hybrid far exceed those of either parent in the range of their variability. The extreme variability of the leaves of the hybrid referred to was estimated at 500 per cent, which has reference to size merely; if other characters were measured the range would be found quite as great, while the extremes in size of the trichomes of these leaves fall under 100 per cent and usually much below that figure.

A comparison of the trichomes shows in general that there is a direct connection between the size and the condition under which they are placed. For example, trichomes which are located on or close to the veins of a leaf are larger than those of the same kind between the veins of the same leaf, and also trichomes of the dorsal surface are usually larger than those on the ventral surface. The difference in the size of the entire trichome extends also to the portion active in secretion--the terminal cells of the multicellular types. Owing to such relation between size and position occupied by the trichomes, it is probable that the variation is to be associated with differences in physiological conditions, as nutritive relations, quite as in the fluctuating variability of larger plant organs.

In general it was determined that each species has trichomes which in form and in size are characteristic of the species, and should it chance, as is usually the case, that both parental lines of a hybrid have trichomes type for type the same, but differing only in size and form, the corresponding trichomes of the hybrid, at least of the first generation and frequently in later generations, hold some degree of intermediacy. But if one pure line bears trichomes unlike those of the other pure line, the odd trichomes are transmitted unchanged either in form or in size. The Solanum hybrid was the only clear case of unilateral inheritance, although Juglans californica $\times$ Juglans nigra almost surely has this type of inheritance also.

Not only do the trichomes vary in size, but certain observations indicate that they have an unequal distribution, so that if in size and form of trichomes the inheritance may be said to be bilateral it may no longer be considered such when the facts of distribution of the trichomes on the members bearing them is taken into consideration. This condition was especially noted in Oenothera hybrid. In the hybrid and in the pure parents the trichomal distribution was observed to be as follows: The pear-shaped trichomes in Oenothera lamarckiana was found on leaf, on stem, and sparingly, on capsule; in Oenothera cruciata the same trichome type was on the leaf, stem, and abundantly on capsule; in the hybrid it occurs on leaf and stem, but not on the capsule. The club-shaped trichomes in Oenothera lamarckiana occur on leaf, stem, and capsule, but in Oenothera cruciata and the hybrid this type is to be found only on the capsule. This observation, and others also, make it probable that the trichomal system is not 
to be taken as a single unit, but rather that it is to be conceived as being comprised of as many units as there are distinct types.

In most of the plants studied it was not practicable to study the origin and development of the trichomes, either from a lack of suitable material or because the trichomes were unicellular. But in Juglans the material for study was the most favorable, so that the ontogeny of the trichomes was followed to a certain extent in all plants, both hybrid and pure species, but particularly was this done in the second-generation materia1. In Juglans both unicellular and multicellular trichomes are found, of which 4 types occur in californica and regia, and an additional type in nigra. The hybrid strain with nigra blood has 5 trichome types, while that with regia blood has but 4 . The trichomes common to all Juglans studied are (1) awn-shaped-unicellular, (2) short secreting, (3) long secreting, and (4) disk-shaped types. The extra form, found in nigra and its derivatives, is a long type with a number of cells in stalk and head. The short secreting trichome has 6 cells, the long secreting type has 8 cells, while the disk-shaped form has 32 or more cells. The 6-celled trichome has a certain sequence in development which it follows with perfect consistency, which also is true of the 8-celled trichome. The latter trichome up to the 6-celled stage has the same sequence in its cell-divisions as that of the smaller form, and to these adds 2 others, which also have a proper sequence. Therefore it seems probable that the two trichomes are especially closely related, and either that one developed out of the other or that one represents an arrested stage of development of the other.

The first 3 cell-divisions of the odd type of trichome, that peculiar to nigra and its descendants, agree in sequence with the corresponding stages in the short and the long secreting trichomes, but in the later development it is different from either. Only the first 2 cell-divisions of the disk-shaped trichome agree with the course of development of the three trichomes just mentioned. This type of trichome, consequently, probably is not so closely related to either of the preceding types as these, particularly the first two mentioned, are to each other.

In addition to the more common form of trichomes in Juglans, abnormal forms and one aberrant type were observed both in the pure lines and in the hybrids. The abnormal trichomes were very evident modifications of the prevailing types; that is, they were short secreting trichomes with an extra cell in the stalk, long secreting trichomes with a stalk of more than 4 cells, or (in trichomes with nigra blood) the odd trichome with more than 8 cells in the head, or, finally, disk-shaped trichomes with a stalk of 3 cells. The aberrant trichome was observed in the second-generation material of both hybrid strains. It had a structure quite different from that of the other multicellular trichomes and it originated in a manner peculiar to itself. It therefore is taken to represent a new type of trichome, and is with little doubt a mutation. 
From a study of the development of the trichomes in Juglans, as just summarized, it would appear that there may be at least two ways they may take their origin. They either may be modifications of types already existing, as illustrated by the abnormal forms and indicated by a comparison of the development of the trichomes, or they may arise suddenly through the circumstance that the initial cell-division is a unique one. In addition to the origination of the trichomes, in the manners described, observations suggested that at least compound unicellular trichomes might arise in quite another manner.

In most of the Juglans studied the awn-shaped trichomes occur singly, but in a few instances they were aggregated into small groups, the elements of which, however, were quite the same as the single trichomes. In such cases it is evident that the more complex trichomes, referred to in foregoing descriptions as stellate trichomes, owe their origin to the fact that several adjacent epidermal cells all give rise to awn-shaped types, and that therefore they can not become separated in the subsequent development of the leaf. The primitive types of trichomes of Juglans may, therefore, be conceived of as being the awn-shaped trichome, in addition to the short secreting trichome and the aberrant type. The possible relationships of these types, and their relation to the other trichome in Juglans, as conceived from their study, is graphically shown in fig. 21.



FIG. 21.-Probable origin and relationship of the trichomes of Juglans. 


\section{SUMMARY.}

(1) The trichomes of the following hybrids, and of the pure parental species, were passed under observation: Juglans californica $\times$ Juglans nigra, $\mathrm{F}_{1}$ and $\mathrm{F}_{2} ;$ Juglans californica $\times$ Juglans regia, $\mathrm{F}_{1}$ and $\mathrm{F}_{2} ;$ Oenothera lamarckiana $\times$ Oenothera cruciata, $\mathrm{F}_{2}$ and $\mathrm{F}_{\mathrm{g}}$; Papaver somniferum $\times$ Papaver orientale, $\mathrm{F}_{1}$; Papaver somniferum $\times$ Papaver pilosum, $\mathrm{F}_{1}$; Solanum villosum $\times$ Solanum guinense, $\mathrm{F}_{1}, \mathrm{~F}_{2}$, and later generations.

(2) The Oenothera hybrid inherits characters from both pure parents, but does not revert to either line.

Three types of trichomes, all of which are unicellular, are found in both parents and in the hybrid Oenothera. Those of lamarckiana are larger than those of cruciata, while the corresponding trichomes are, in the hybrid, of an intermediate size. Both in the hybrid and in the pure parental lines the trichomes which occur on or in the close vicinity of the veins of the leaf are larger than those between the veins of the same leaf.

The distribution of the trichomes is unlike in the two pure lines and in the hybrid. In lamarckiana both types of glandular trichomes are found on stem, leaf, and capsule; in cruciata the pear-shaped trichome occurs on the same regions, but the club-shaped trichome is found on the capsule only. In the hybrid the club-shaped trichome only occurs on the capsule, in this particular exhibiting a cruciata character, but no other type of trichome is found on the capsule in which the hybrid is different from either pure parental line. The peculiar quality of distribution is held to indicate the independence of each type of trichome as a character.

(3) Two strains of Papaver hybrids were examined, both of which were sterile, so that the first-generation plants only were available.

Only one type of trichome is found in Papaver, both in the hybrids and pure species, which has, in the hybrids, an intermediate structural character.

(4) In the Solanum hybrid and pure species 2 types of trichomes are found, but of these one type only is common to both parental lines and the hybrid. The second type occurring in the hybrid is inherited from the guinense line.

Although as regards the trichomal character the Solanum hybrid has unilateral inheritance, in another regard it possesses a new characteristic, the flavor of the fruit, which, in all the material examined, was seen to be a constant character.

(5) In Juglans, pure species, 4 types of trichomes, 3 of which are multicellular and glandular and 1 unicellular and lifeless, are found in each species. Nigra and nigra derivatives have, in addition, a form peculiar to themselves. Each form of trichome has a manner of development to which it adheres with great constancy. Numerous measurements show that the 
trichomes of each pure species have a characteristic size and form, but that a considerable range of variation, which is always associated in a very definite manner with the position occupied on the leaf, or with the age of the leaf, is to be found both in form and in size.

The first and the second generations of the Juglans hybrids were examined. The first-generation hybrids of both strains, as regards the leaf-characters, are intermediate although not strictly so. Dominance was not observed. Each hybrid bears all of the trichomes found in both parents, which in the nigra derivative is one more than in the other hybrid, owing to the fact that pure nigra has one more type of trichome than occurs in regia or californica.

So far as followed each form of trichome, type and type, had the manner of development which was seen for it in the pure lines. In size and form the trichomes are intermediate between the same characters of the trichomes in the pure lines, and also in the hybrid they exhibit a variation directly associated with the position which they occupy on the leaf or with its age.

The second-generation hybrids of Juglans do not exhibit reversions in gross leaf-characters to either pure line. The course of development of trichomes in both strains was followed closely and it was learned that each trichome type has the same sequence of cell-division in development as was seen for the particular trichome in $F_{1}$ and the pure lines. The 6-celled trichome has a certain form of development, which the 8-celled type follows exactly up to the 6-celled stage and then it adds 2 divisions peculiar to itself. The other multicellular trichomes agree with the sequence of these divisions in the early stages only.

In the hybrids of the second generation, both strains, abnormal trichomes were seen. These were very evident modifications of types already existing. One aberrant type also was found, which was quite different from any occurring commonly on the leaves. The aberrant trichome originated by divisions which were essentially different from those of the usual trichomes, and there are no intermediate forms between the aberrant trichome and the other types, from which facts this type is held to be a mutation.

(6) The trichomes of Juglans are thought to arise from three types, namely, the awn-shaped, the 6-celled (short secreting), and the aberrant trichomes. By the conversion of all of the epidermal cells of a group into awn-shaped trichomes, stellate types arise; by the processes of arrested development, or the fixation of minor variations (such as the abnormal trichomes), or by mutation, the multicellular trichomes have originated. In Juglans the largest number of types of trichomes seem to have arisen by the second and third means. The aberrant form represents a type which, by such variation, would be the ancestor of still other kinds of multicellular 
trichomes. Should each kind of trichome represent a distinct character, as seems possible, we have here several methods by which unit characters may take their origin.

(7) In Juglans there is no direct relation between the size or vigor of the leaves or plant and the size of the trichomes, although position on the leaves directly affects size and form of the trichomes.

(8) In the second generation of Juglans californica $\times$ Juglans nigra the short secreting trichome, in size and form, reverted to nigra. No other case of reversion to one pure line, of a character of trichome common to both pure lines, was observed in Juglans. 


